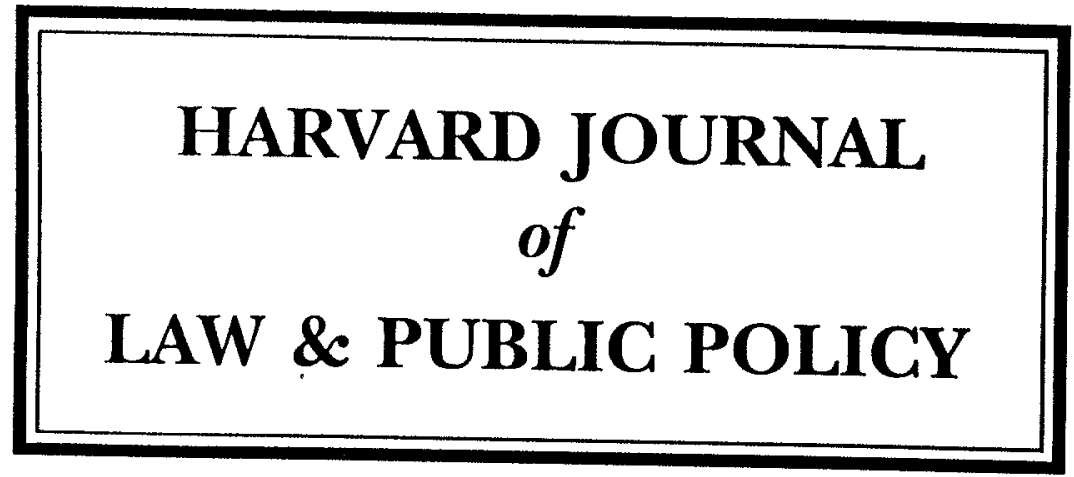

VOLUME 17, NUMBER 2

SPRING 1994

Anttrkust Immunity: State Action and Federalism,

Petmioning and the First Amendment

David McGowan

Mark A. Lemley 


\title{
ARTICLES
}

\section{ANTITRUST IMMUNITY: STATE ACTION AND FEDERALISM, PETITIONING AND THE FIRST AMENDMENT}

\author{
David McGowan* \\ MARK A. LEMLEY**
}

In recent years, the United States Supreme Court has focused increasing attention on two doctrines that provide immunity from antitrust liability for certain anticompetitive activity: the state action doctrine and the petitioning immunity doctrine (sometimes known as the Noerr-Pennington doctrine, after the two cases that established it). These doctrines have been the subject of seven Supreme Court decisions in as many years. In spite of (or perhaps because of the Court's numerous recent decisions, there remains a great deal of confusion about the source and the scope of these doctrines. This Article attempts to clarify both doctrines.

The Supreme Court and a number of commentators contend that the antitrust immunity doctrines are the product of statutory interpretation of the antitrust laws themselves. The Court contends that petitioning and state action are "essentially dissimilar" to the types of business activity the antitrust laws were designed to regulate. This Article disagrees. Both petitioning and state action present precisely the sorts of problems with which the antitrust laws are concerned-exploitation of consumers through the charging of supracompetitive prices.

To determine the source of antitrust immunity, the Court must look beyond the antitrust laws to the constitutional principles that are implicated by the doctrines. For the state action doctrine, the constitutional principle at stake is langety one of federalism, and the more general democratic principles embodied in the Court's non-delegation jurispmudence. For the petitioning immunity doctrine, the First Amendment protection of speech and petitioning provides the relevant principles. After examining the source of the antitrust immunity doctrines,

* Associate, Skadden, Arps, Slate, Meagher \& Flom, San Francisco, California. B.A University of California at Lss, Angeles; D Univenity of California at Berkeley School of California at Los Angeles; J.D., Univerity of California at Berkeley School of Law (Boalt Hall).

** it posturer, $U$.

(Boalt Hall); Associatc. \&c Richardson, Menlo Park, California. A.B., Stanford University; J.D., Boalt Hall School of Law, Univerity of Califomia at Berkeley. I would like to thank Rose for the weekends and evenings we gave up for this piece.

This paper has benefited from helpful comments provided by Einer $R$. Elhauge and Peter S. Menellh and from workshops held at the Geonge Mason University Law School, Peter sity of Iowa School of Law, and the University of Texas School of Law. 
this Article considers the appropriate scope of those doctrines in light of the constitutional principles at issue.

INTRODUCTION $\ldots \ldots \ldots \ldots \ldots \ldots \ldots \ldots \ldots \ldots \ldots \ldots \ldots . \ldots \ldots$

I. 'Tile Development of Antitrust Immunity........ 301

A. Parker $v$. Brown ....................... 301

B. Noerr.............................. 305

C. Immunity After Noerr-The Search For A Theory ... 308

II. Sifate Action Immunity As A Federalism Doctrine.. 315

A. Essential Dissimilarity................... 315

B. Explaining the State Action Doctrine............. 322

1. The Public Interest, the Public-Private

Distinction, and Public Choice Theory ..... 323

2. Clear Statements, Active Supervision, And Principles of Governance: How Panama Refining Co. v. Ryan and Deterrence Theory Became Part of The Antitrust State Action Doctrine ...................... 343

3. Recommendations.................... 356

III. NOERR As A First AMENDMEnt Doctrine ......... 360

A. The Uneven History of the Essential Dissimilarity

Rationale In Petitioning Immunity Cases.......... 363

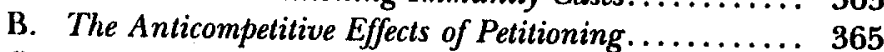

C. Petitioning Immunity as a First Amendment Doctrine. 370

1. The Structure of Government And Some

Premises for Petitioning .............. 371

2. The Misplaced Concern Over Chilling Speech in Judicial "Fora" ............... 390

3. Recommendations.................... 399

Conci.usion $\ldots \ldots \ldots \ldots \ldots \ldots \ldots \ldots \ldots \ldots \ldots \ldots \ldots \ldots, 400$

\section{INTRODUCTION}

Arizona state Senator Manuel Pena is a man with a firm grasp of reality. The Bank of America was on its way to completing its purchase of Security Pacific Bank, which threatened to consolidate ownership of over thirty percent of the deposits in Arizona in the hands of one bank. Senator Pena declared that the Arizona legislature would prevent the acquisition by amending the state's antitrust laws to prohibit sole ownership of over thirty percent of the deposits in the state. He had not heard that the Bank of America was divesting itself of enough Arizona deposits that it would own only twenty-nine percent, but the news did not throw him. The state would just drop the cap to twenty-five percent, he said. In Pena's words, "The Senate giveth, and the Senate taketh away."

Senator Pena has it right. State and local governments have enormous power to rearrange the competitive landscape in almost any field. That power, the circumstances in which it may be exercised without interference from the federal antitrust laws, and the manner in which constituents may seek to have that power exercised in their favor, are the subjects of this Article.

Antitrust is about competition-what practices are competitive, what practices impermissibly restrain competition, and how to tell them apart. ${ }^{2}$ The rules dividing permissible methods of competition from impermissible restraints are reasonably clear in many cases. A firm can set its prices with an eye to its competitor's prices, ${ }^{3}$ for example, but it cannot agree with its competitor what those prices should be. ${ }^{4}$ Some practices are closer to the line than others, but the debate is at least well-defined. Whether vertical nonprice restraints are illegal per se or are subject to the rule of reason may never be settled for the commentators, ${ }^{5}$ for example, but the ground they are arguing about is fairly clear. ${ }^{6}$

There are many ways to compete, and there are at least as many ways to restrain competition. One of the ways a firm can compete is by asking the government to confer a benefit on the firm or to impose a burden on its competitors. Firms compete in this political "market" for economic benefits they cannot otherwise get in economic markets. This political market has both legal and economic significance, but its competitive processes differ in many important respects from the processes in eco-

1. Arizona Bill Targets $B$ of A, S.F. Chron., Feb. 19, 1992, at B1 col. 4.

2. On this point, courts and commentators agree. See, e.g., National Society of Profes2. On this point, courts and commentators agree. See, e.g., National Society of Profes-
sional Engineers v. United States, 435 U.S. 679, 697 (1978) (invalidating under the Sherman Act a canon of professional ethics that makes competitive bidding unethical); Pichard A. Posner, AntTtrust Las

3. See In re Coordinated Pretrial Proceedings in Petroleum Products Antitrust Litigation, 906 F.2d 432, 444 (9th Cir. 1990). Of course, price interdependence may in some cases be evidence of a conspiracy, which is illegal. Id. at 446-50.

4. To do so would constitute horizontal price fixing, which is illegal under section 1 of the Sherman Act, 15 U.S.C. \& 1 . For a full discussion of the issues raised by such practices, see, e.g., Phil.uip Areeda \& Louis Kaplow, ANTITRUst ANaissis $187-275$ (4th ed. 1988). 5. The Supreme Court, however, has had its say. See Continental T.V., Inc. v. GTE Sylvania, Inc., 433 U.S. 36 (1977) (evaluating vertical territorial market division under the rule of reason).

6. Compate Larry Sulunan, Handbook of the Law of AnttrRust 399-431 (1977) with Robert H. Bork, The Antitrust Paradox: A Policy at War with Itsel. 280-298 (1978) [hereinafter Bork, Antitrust Paradox] 
nomic markets. Companies that turn to the political markets to gain a competitive advantage almost always do so in order to achieve an anticompetitive result. If they could achieve the same result legally in the market-through innovation or more efficient management, for example-the company would do so and save the costs of transacting with the government. ${ }^{7}$

To choose a not completely random example, if a raisin grower wanted to join together with his competitors and pool their output to stabilize (raise) prices, the grower would be liable under the Sherman Act. ${ }^{8}$ If the raisin growers collectively lobbied the government to set up their cartel for them, however, their conduct probably would not subject them to antitrust liability. ${ }^{9}$ This would be so even though the growers could reap profits laining a the market price and the private cartel price by obtaining a governmental imprimatur on their actions. This immuprofits, are the liability, and the attendant supracompetitive profits, are the results of the antitrust "state action" doctrine.

The political market also differs from economic markets because the rules of the game in the political market have a constitutional spin to them. In a democracy, citizens are supposed to communicate their wishes, anticompetitive and otherwise, to their representatives, who are supposed to respond. However badly this might break down in practice, in theory it is "the essence of self-government," 10 and is by and large protected by the Speech and Petition Clauses of the First Amendment. But petitioning, in and of itself, can have dramatically anticompetitive effects, even if the petitioning is unsuccessful. Firms may waste scarce resources lobbying the government to ban a new product rather than develop a competitive product of their own. If many firms do so, the value to the consumer of a new product or a new competitor may be completely wasted through the expenditures used to fight the new development. Such effects are com-

7. In addition, firms may compete for political benefits out of fear that their competiThus, the incentives to seekstead and unfairly exclude them from the economic market. as well as obtaining them for oneself See infra novolve denying those benefits to others 8. These are he the infra note 353.

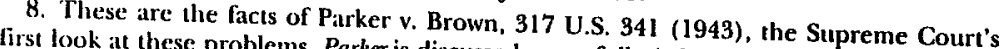
lirst look at these problems. Parker is discussed more fully infra notes 33-51 and accompa-
nying text.

9. Id. at 351-52. 10. Garrison v. Louisiana, 379 U.S. $64,74-75$ (1964) (holding that state libel laws cannot
punish true statements about public officials). pounded when a petitioner succeeds in obtaining the assistance of a state or local government in implementing its plan.

Thus, a statutory preference for competition may conflict with a constitutional mandate for self-government and freedom of speech. Stated this way, the solution to the problem sounds easy. In any conflict between a constitutional provision and a statute, the Constitution must prevail. Unfortunately, the Supreme Court's treatment of this problem in a series of cases beginning with Eastern Conference of Railway Presidents v. Noerr Motor Freight, ${ }^{11}$ has created needless confusion because the Court has nominally grounded its decisions in the antitrust laws instead of the Speech and Petition Clauses of the First Amendment. ${ }^{12}$ We thus have the antitrust petitioning immunity doctrine, which holds the antitrust laws do not apply to firms' petitioning activity, even if the petitioning itself has anticompetitive effects and is not protected by any constitutional provision. ${ }^{13}$

The state action and petitioning doctrines have some important things in common. First, both doctrines deal with important questions involving the relationship between government and its constituents. For example, if a small group of constituents wants the government to transfer wealth to it from other constituents using a restraint of trade as the mechanism, is that permissible? Under what circumstances is it permissible, and what methods may the group use to obtain the transfer? The Supreme Court's current answer is that there is no antitrust problem. As stated in City of Columbia v. Omni Outdoor Advertising, Inc., ${ }^{14}$ at least with respect to requests directed at state legislators or those vested with state authority, the antitrust immunity doctrines "are complementary expressions of the principle that the antitrust laws regulate business, not politics; [Parker] protects the States' acts of governing, and [Noer] the citizens' participation in government." 15

That the antitrust laws "regulate business, not politics" is a truism supported only by the Court's repeated recitations. This Article will attempt to show that the Court's opinion in Omni, which reflects the Court's consistent statement of the doctrine in both state action and petitioning cases, implies two things that are not

\footnotetext{
11. 365 U.S. 127 (1961).

12. Id. at $135-36$.

13. See infra notes $333-38$ and accompanying text.

14. 499 U.S. 365 (1991).

15. Id. at 383 .
} 
true: First, that in the cases arising under Parker and Noerr there is a meaningful difference between politics and business and, second, that such a distinction, were one to be made, could be based on antitrust principles. In reality, both petitioning and state action may have severe anticompetitive consequences for consumers, and both legislators and constituents may behave in ways more commonly associated with Wall Street than with Pennsylvania Avenue.

There is an additional similarity between the doctrines, which helps to explain the confused state of the cases. The Court decided Parker and Noerr using a common methodology. In both cases the Court noted that the issue before it presented a potential conflict between important constitutional principles and strict adherence to the antitrust laws. ${ }^{16}$ In both cases the Court construed the antitrust laws so as to avoid the conflict, implicitly following a principle most famously enunciated in Crowell v. Benson ${ }^{17}$ and Ashwander v. Tennessee Valley Authority. ${ }^{18}$ In Parker, the Court said that " $[w]$ e find nothing in the language of the Sherman Act or in its history which suggests that its purpose was to restrain a state or its officers or agents from activities directed by its legislature." ${ }^{19}$ In Noerr the Court expressed the same thought more clearly, declining to apply the Sherman Act to the conduct before it in part because " $\mathrm{t}]$ he right of petition is one of the freedoms protected by the Bill of Rights, and we cannot, of course, lightly impute to Congress an intent to invade these freedoms." ${ }^{20}$

The Court's avoidance tactic has created doctrinal confusion. Because the Court said in Parker and Noerr that it was construing the antitrust laws, albeit in light of substantive constitutional principles, subsequent students of those opinions, judicial and otherwise, have focused their attention on the antitrust laws. ${ }^{21}$ This Article contends that those who look to the antitrust laws for answers about state action and petitioning immunity are looking in the wrong place. The Delphic simplicity of the Sherman Act offers no answers to the very ambiguous questions these cases present. Simply put, when the Court construes a statute to avoid

16. Noerr, 365 U.S. at 138 ; Parker, 317 U.S. at 350.

17. 285 U.S. 22, 46 (1932) (holding that statutes are to be construed to be consistent with the Constitution if possible).

18. 297 U.S. 288, 341 (1936) (Brandeis, J., concurring) (holding that the Court should

not rule on constitutional questions if the issue can be avoided).

19. Parker v. Brown, 317 U.S. 341, 350-51 (1943).

20. Nour, 365 U.S. at 138 .

21. See infra notes $67-107$ and accompanying text. a conflict with a constitutional principle, one must look to the scope of that principle for the answer to the question whether the statute applies. For if the principle applies, the statute will not.

Thus, in the state action cases, an explanation for the Court's cases and the development of the doctrine must be found in substantive principles of governance expressed in the Court's respect for the role of the states in our federal system and in principles analogous to the famous non-delegation doctrine, which has enjoyed a quiet renaissance in one line of the antitrust state action immunity cases. ${ }^{22}$ The Court must draw a line between state action that in some meaningful sense represents governance and state action that more closely resembles the legislature brokering benefits from one group of constituents to another. ${ }^{23}$ Public choice theory assists this analysis by providing a model of legislative behavior against which the Court's somewhat poorly articulated notions of federalism may be tested. The line between governance and brokering is of course unclear, but there is a distinction to be made here. The first point is that the distinction is made using principles of federalism, not antitrust. ${ }^{24}$

The Court's present line between brokering and governance is oddly formed and oddly placed. The Court has created a formal rule under which direct acts by a state legislature (or a local legislature acting with state authority), such as passing a law that itself

\footnotetext{
22. See infra notes $236-299$ and accompanying text.

23. Id.

24. To address an obvious first objection, we note at the outset that the inquiry we advocate here is not the search for "traditional governmental functions" that so vexed the Court in the cases between National League of Cities v. Usery, 426 U.S. 839 (1976) (striking application of minimum wage and maximum hour provision of Fair Labor Standards ing application of minimum wage and m. San Antonio Metropolitan Transit Authority, 469 Act to state governments), and Garcia v. San Antonio Metropolt local government employU.S. 528 (1985) (holding that Congress may require state and local government employers to pay overtime wages under Fair Labor Standards Act). The approach we advocate in this Article is not concerned with identifying areas reserved to the states to regulate, Rather, the approach we advocate seeks to ascertain whether a state is actually governing, as opposed to bartering its power to immunize an anticompetitive program, without regard to the scope of the states' power to govern. The Court should be indifferent to the states' policies

Similarly, the approach we advocate is constitutional in the sense that it is based on general principles of governance, not on the Supremacy Clause. The vague contours of the Sherman Act do not easily lend themselves to Supremacy Dlause analysis. The analysis might be different with a more specific federal statute. Certainly a federal statute that regulated the ability of municipal utilities to control access to electric power on the part of neighboring utilities who were potential competitors would be more likely to prevail against a state action immunity argument than would a general federal mandate that competition is good.
} 
restrains competition or granting an exemption from regulation, are immune from scrutiny. Omni is the best example of this rule, which, as the Court stressed in that case, is based on the fear that state and local legislation would be "chilled" by the prospect of that "indirect" state ${ }^{25}$ By contrast, the Court has repeatedly held rate scive firms to set a not entitled to that becomes effective unless the state vetoes it, are Court's purposes when immunity. ${ }^{26}$ Acts are "indirect" for the cloak" for a system of the state involvement is merely a "gauzy the Court employs techniques restraints. ${ }^{27}$ As a practical matter, ing the nondelegs techniques similar to the reasoning underlyRya $^{28}$ ) to detegation cases (such as Panama Refining Co $v$. erning authority to a private the state has delegated its govindirect and is not imivate party. ${ }^{29}$ If so, the restraint is deemed In the and is not immune from antitrust scrutiny.

fairly clear ground cases, the Court has recently set forth some frative agencies ${ }^{30}$ bules for "petitioning" of courts and adminismunity for petitioning these rules (and the rules governing imThis conceptual deficin in other fora) lack conceptual coherence. emerging from the petitionists because the basis for the rules emerging from the petitioning cases is even more vague than in the state action cases. The Court is clear that it does not want to encroach on the First Amendment rights identified in Noerr and elaborated in later cases. ${ }^{31}$ But the Court has not used First Amendment principles in defining the scope of the doctrine. The scope of petitioning immunity has been broader than would be justified by the First Amendment. The result has been a doctrine developed solely by the desire to avoid a problem-trampling upon First Amendment rights-without reference to a theory that tells us when that problem arises or why. Without such a theoretical basis, there is no way to say that the result in a given case was right or wrong, and there is no theoretically sound way to predict, ex ante, what actions will and will not receive im-

25. Omni, 499 U.S. at 382

26. See, e.g., Federal Trade Comm'n v. Ticor Title Ins. Co., 112 S. Ct. 2169 (1992). Liquor Dealers Rate Carriers Conf. v. United States, 471 U.S. 48 (1985); California Rea 27.

06 (1980). 28. 293

28. 293 U.S. 388 (1935)

30. See, e.g., Professional Real Estate Investors, Inc. v. Columbia Pictures Indus., $113 \mathrm{~S}$ munity. In the state action cases, the Court at least relies expressly on principles of federalism, even if it has not defined what those principles are. The petitioning cases have no such intellectual foundation.

Principles of substantive First Amendment law should dictate the results in the petitioning cases. Petitioning in and of itself can have substantial anticompetitive consequences. There is thus no basis for the contention that petitioning is not the kind of conduct with which the antitrust laws are concerned. The only reason for exempting petitioning activity is that the Constitution takes precedence over the antitrust laws. It follows that when the First Amendment protections of speech and petitioning are inapplicable, anticompetitive petitioning activity should be subject to antitrust liability, assuming the substantive requirements of antitrust law are met. The Court's treatment of petitioning immunity should follow First Amendment doctrine. Previous petitioning cases should be modified or rejected to the extent they are inconsistent with First Amendment principles. ${ }^{32}$

The Court is correct in one respect-Parker and Noerr do have much in common. The similarities, however, are not found in the antitrust laws and have nothing to do with a search for an illusory distinction between politics and business. Rather, both doctrines work at the intersection of antitrust and governance. The contours of both doctrines should be determined by the fundamental goals and values of democracy in our constitutional system. These constitutional principles will necessarily constrain enforcement of the antitrust laws. Conversely, the antitrust laws should be constrained only to the extent dictated by these principles.

\section{The Development of Antitrust Immunity}

\section{A. Parker v. Brown}

We begin the discussion of both doctrines where the Court began it-in 1943, with the case of Parker $v$. Brown. ${ }^{33}$ Parker dealt with the validity of the California Agricultural Prorate Act, ${ }^{34}$ a

32. Of course, if a state action was inconsistent with the First Amendment it would be unconstitutional. The inconsistencies we discuss in this Article involve the Court and others giving more protection to anticompetitive activity than the First Amendment can provide.

33. 317 U.S. 341 (1943)

34. Act of June 5, 1933, ch. 754, 1933 Cal. Stat. 1969. 
period piece of state legislation governing the California raisin Adjustment Act that had been and modeled on the Agricultural then reenacted as President Roesered unconstitutional ${ }^{35}$ and the New Deal. ${ }^{36}$ According to the Court the Court fought over consumed in the United States, and "almost all the raisins crop," were produced in the quaintly-name-half of the world Zone No. 1. ${ }^{37}$ Times, it will be recalled and raisin producers were be recalled, were hard in the 1930s, ness as they accumulated threatened with the loss of their busimeted. ${ }^{38}$ To protect the raisin crop surpluses and prices plumallow them to form a cartel to growers, California decided to the state's enform a cartel to reduce raisin output, and to throw itate's enforcement authority behind the cartel. ${ }^{39}$

More specifically, the Act allowed producers in a given region to request the formation of a government in a given region posed, not incidentally, of the raisin producommittee-comthemselves ${ }^{40}$ - which would propose a producers and packers (and therefore increasing prices) a plan for reducing output plan was presented to the California devised, a committee's soly Commission, the California Agricultural Prorate AdviCommission did was then sent modify or reject it. Whatever the who voted on it. The producers thus the producers themselves, a restriction would be adopted by the state final say on whether surprisingly, the result in Raisin Pror state of California. ${ }^{41}$ Not $70 \%$ of the raisin crop was taken off the Zone No. 1 was that

5. United States v. Butler, 297 U.S. 1 (1936)

36. Good descriptions of the history of the Prorate Act may be found Vetkuil, State Action, Due Process and Antitrust: Reflections on Parker be found in Paul R. L. Riv 7 , Wiley, Jr., A Capture Theory of Antitrust Foderalism ColuM. L

37. Parker 317 (1986) [hereinafter Wiley, Capture Theory]

38 .

production. 1 d. at 364 n. 10 .
producers were selling raisins at prices below the cost of 39. Id. at 346.

40. Id. at 346. The Act provided that committee menbers would be chosen by rasin

growers and packers, presumably from their own members would be chosen by raisin 41. Id. a 347. This feature of the their own ranks. Id

commentators secking to reconcile Parker with later state action cared by the Court and by Retail I.iquor Dealers Ass'n v. Midcal Aluminum, Inctate action cases. See, e.g., California Parker turned on "extensive official oversight").
42. All raisin growers in 445 U.S. 97, 104 (1980) (claiming

inspection. There, all "nonmarketable" raisins were to deliver their goods to the state for ever, at least $20 \%$ of the raisins delivered had to removed. According to the plan, howdone, the state then put fully $50 \%$ of the entire crop into a "stabilization petable." That the:y threw them away. Raisin growers could then market the remaining $30 \%$ of their
crop, after paying a fee to the state of $\$ 2.50$ per ton.
One might ask why California legislators would pass such a law. After all, more people eat raisins than grow them, so one would think a legislator would prefer to keep raisin prices low. ${ }^{43}$ In a perhaps excessively candid preamble to the Act, the legislature provided its answer: "[ $t]$ he unreasonable waste of agricultural wealth" occasioned by the overproduction of raisins "is creating chaotic economic conditions in certain agricultural areas of the State of such severity as to imperil the ability of agricultural producers to contribute in appropriate amounts to the support of ordinary governmental and educational functions, thus . . . increasing the tax burdens of other citizens for the same purpose." ${ }^{44}$ In other words, raisin prices were down, so the raisin growers were making less money and the legislature was receiving fewer tax dollars.

Leaving aside the entire idea that raisins were being "overproduced," ${ }^{45}$ the state's asserted reason for raising raisin prices-to be able to collect tax revenues from raisin growers-smacks more of fiscal self-interest than of a genuine concern for the public welfare. The state's justification was particularly troubling because ninety to ninety-five percent of the raisins grown in California were sold outside California. ${ }^{46}$ Thus, the overwhelming majority of the higher prices charged by the raisin cartel would be paid by consumers in other states, who had no say over whether California legislators remained legislators from year to

43. This intuitive statement is wrong. Even if the majority of the raisins were sold in California, consumers would have had a tough time fighting the Act because of free rider problems. There are many consumers, each paying a slightly higher price for raisins because of the Act. There are far fewer raisin growers, each reaping a relatively substantial benefit from the Act. Under these circumstances, growers are far more likely than consumers to act collectively to influence the legislature. Each consumer rationally is unwilling to bear the costs of petitioning by herself, and will wait for someone else to do her job
for her.

Consumers might try to get around this problem by banding together, so that each bears only part of the cost. But, as Mancur Olson and countless others have shown, such efforts are largely doomed to fail. See Mancur Oison, The Logic of Coll.zctive Action $127-28$ (1971). Someone must bear the cost of organizing, as well as her share of the cost of petitioning. Potential organizers are at least as likely to free ride as potential petitioners.

44. 1933 Cal. Stat. $1969, \S 1$.

45. If farmers truly were losing money growing raisins, they might have shifted their land to a more profitable crop or, if that were not possible, ceased to be farmers. From the farmer's perspective, this economic answer is undeniably harsh. On the other hand, so was California's solution-raising food prices across the country in the midst of a depression. In any event, California seems to have been less concerned about overproduction of raisins-a problem which would have taken care of itself, particularly if raisin growers were pricing below cost, as the Court suggested-than it was about ensuring the continued employment of too many raisin growers.

46. Parker, 317 U.S. at 345. 
year. One could view the Act as a deal between raisin growers and state's cut coming fromers nationwide and split the take-the wanted to collect from the increased tax revenues it admittedly object to the Act, Can the likely to raisins, if they were benefiting they were paying higher prices for increased state benefits than from either decreased tax rates or cartels. ${ }^{47}$

Perhaps this is too cynical. Perhaps the reference to tax revenues meaps the California legislature's the best interests of all (Calif only that it felt the Act was in case tions about the one cannot avoid some deeply disturbing quesstructured the propriety of California's actions. As the Act was cartels. The state mers had virtually unlimited control over the cartels. The state merely provided a compulsory enforcement

ticompetitive effects) tremendously. ${ }^{48}$ of the cartel (and its an-

trade war. Whatever the meritse Act was nothing less than a declaration of interstate clear to us that the Court should of the Court's answer to the antitrust question, it seems Commerce Clause. The Court's answer to the Act unconstitutional under the Dormant sive, to say the least. The Court first argued that the Act Clause argument was unpersuatered interstate commerce, rendering the Comat the Act affected raisins before they enU.S. at 361 . This argument is mere sophistry. Following the Coupplicable. Parker, 317 could avoid all constitutional limits on its regulatory powers by Court's reasoning, a state agencies somewhere in the chain of distribution. This powers by setting up state purchasing coming from a Court that had only a year earlier held that was particularly baffing tended to regulation of wheat grown and cansuer held that the commerce power exburn, 317 U.S. 111 (1942). clucled that California had adequately balanced "thesting on this theory alone. It also con national interests involved." Parker, 317 U.S. "the competing demands of the state and cerned that the plight of California's raisin farme at 362. In particular, the Court was conpractical difficulties involved, may never be adequa "because of its local character and the nothing less thin a rejection of the Dormant Couately dealt with by Congress." Id. This is stitutional protection loses all force if it is up Commerce Clause doctrine itself. That con they are violating its provisions by if it is up to the states themselves to determine when Finally, the Court reasoned by discriminating against interstate commerce. merce at all, because Callifornia consumers did not discriminate against interstate comBut the entire point of the Act consumers had to pay higher prices as well. Id. at 367-68. remained within California whilem California's perspective was that all of the Commerce Clause has few while most of the burdens were shipped ont of state. The sumers can save a law few teeth if the imposition of a small burden on California con consumers.

emerged from an era of striking down Newe noted, a period piece. The Court had just grounds and it was deterriking down New Deal legislation in part on Commerce Action: Economic Efficiency aned not to go back. See Merrick B. Garland, Antitrust Clause 48. This is because cartist havel Process, 96 YA..E L. J. 486 (1987)

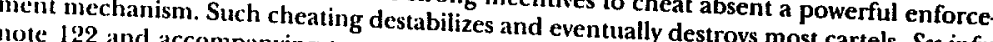

In the end, the state brought one more thing to the cartelantitrust immunity. Because the state was involved, the Court held that the raisin growers were not liable under the antitrust laws. As the Court put it, "We find nothing in the language of the Sherman Act or in its history which suggests that its purpose was to restrain a state or its officers or agents from activities directed by its legislature. ${ }^{29}$ While Congress did have that power, the Court was unwilling "lightly" to attribute "an unexpressed purpose to nullify a state's control over its officers and agents. ${ }^{\mathrm{MO}}$ Further, the raisin growers were entitled to ride the state's coattails, immune from antitrust liability, even though the growers proposed, orchestrated, controlled, and stood to benefit from the restrictions imposed by the Act..$^{31}$

\section{B. Noerr}

Parker implied that if a state was immune from antitrust liability for enacting anticompetitive restraints, one could hardly punish those who asked that such restraints be enacted. ${ }^{52}$ Parker's implication regarding petitioning activity was made explicit in Eastern Railroad President's Conference v. Noerr Motor Freight, Inc. ${ }^{59}$

The Eastern Railroad President's Conference was a trade association of East Coast railroad companies concerned about competition from the emerging long-haul trucking industry. Unwilling or unable to compete in the market, ${ }^{54}$ the railroad companies jointly funded a massive and rather heavy-handed lobbying and media attack on the truckers, designed to procure protective legislation from the state government. ${ }^{55}$ While the railroads did not succeed in their immediate goal-persuading the Pennsylvania legislature to bar heavy trucks from Pennsylvania freeways-they did manage to convince the governor to

\footnotetext{
49. Parker, 317 U.S. at 351

50. Id. at $350-51$.

51. Id. at 352.

52. On its facts Parker went even farther, granting immunity to the private actors who actually controlled the raisin cartel, but that aspect of the opinion has become the victim of selective judicial memory in later cases. See, e.g., California Retail Liquor Dealers Ass'n v. Midcal Aluminum, Inc., 445 U.S. 97, 104 (1980) (invalidating California's resale price maintenance scheme for wine because it was insufficiently supervised by the state). 53. 365 U.S. 127 (1961)

54. This is perhaps unfair. It is possible that railroads could have competed successfully with trucks (though history would seem to suggest otherwise). Nonetheless, any rational businessman would prefer not to face competition if he did not have to, and the railroad presidents felt they had found a way to avoid competition.

55. Id. at 129 .
} 
vince a number of Pennsylvania red. They also managed to cona bad idea. ${ }^{56}$

The truckers sued the res spired to restrain trade in violation, claiming the latter had conAct. The truckers prevailed in the of Section 1 of the Sherman

Court reversed. It reasoned:

[T] he Sherman Act does not

from associating together in an attempt to or more persons lature or the executive to take particular to persuade the legisa law that would produce a restraint or action with respect to such associations could perhaps, through a proply. Although sive construction, be brought within the a process of expanof "combinations[s] . . . in restraint of general proscription little if any resemblance to restraint of trade," they bear very violative of the Sherman Act, combinations normally held terized by an express or implied agreement ordinarily characthat the participants will jointly agreement or understanding help one another to takeintly give up their trade freedoming through the use of such devices as price freedom of others boycotts, market-division agreements, and agreements, arrangements: ${ }^{57}$ agreements, and other similar

This language appears unambiguous. If it is to be believed, the Court was not immunizing anything. Rather, the Court was sim-
ply considering-and rejecting-applitioned the to a new type of claim: one of anticompen of the antitust laws petitioning.

There are a number of we discuss in detail in Part III. For with this conclusion, which petitioning activity is often precisely the it is enough to note that the antitrust laws have always (and the sort of thing with which haps cognizant of the anticompetitive posseen concerned. Perthe Court did not end its analysis theressibilities of petitioning,

This essential dissimilarity bets there. It continued:

seek legislation or law enforcement an agreement jointly to tionally condemned by $\$ 1$ of the Act, even if not itself conclu-
sive on the question constitute a warning against treatingability of the Act, does as though it amounted to a common the defendants' conduct we clo think that the question is the application of the Act, when is conclusively settled, against larity is considered along with the other difficuliential dissimi-

be presented by a holding that the Sherman Act forbids associations for the purpose of influencing the passage or en-

The Court identified two such "other difficulties" which combined to produce this result. The first difficulty was that "the whole concept of representation depends upon the ability of the people to make their wishes known to their representatives. ${ }^{n 9}$ Because government is supposed to be responsive to the demands of the electorate, the Court was unwilling to punish the electorate for making those demands. This difficulty was tied directly to Parker, which the Court cited in support of its concerns. ${ }^{60}$

The second difficulty the Court identified was the First Amendment right to petition. ${ }^{61}$ This difficulty was simply a more specific statement of the general concern about representation. In order to facilitate representation, the Constitution guarantees the right to petition, which may not be infringed by a statute. The Court did not explicitly conduct a First Amendment analysis, however, preferring instead to avoid confronting the "important constitutional questions" that might be raised if it had ruled the other way. ${ }^{62}$

According to this analysis, Noerr creates a sort of penumbra around the state action doctrine in which anticompetitive petitioning may take place without antitrust liability. Noerr protects not only those private actors who obtain governmental benefits at the expense of their competitors, but private actors who seek government action, regardless of whether their petitioning is successful.

This penumbra is a fairly dramatic expansion of the immunity provided in Parker. That decision was based on the idea that in a federal system, state legislative choices are entitled to some deference so long as certain conditions are met. ${ }^{63}$ Where the state does not act, however, there is no occasion to invoke such deference. Noerr's intellectual foundations, while related to Parker, are thus conceptually distinct. ${ }^{64}$

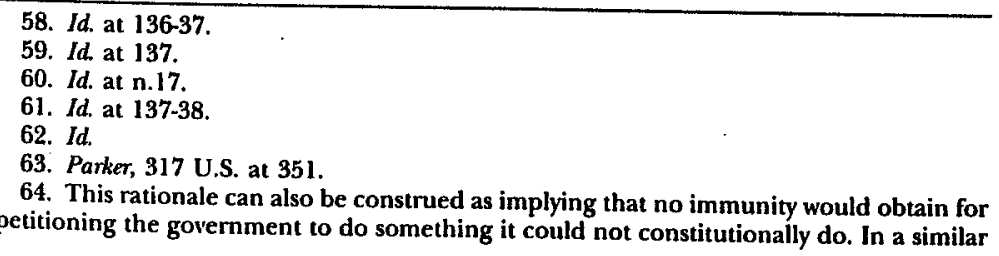


But what if the government, particularly a state governn had no power to restrain trade? What if Lo state government, law of the land, or if the "business aff if Lochner" were still the doctrine of Munn $v$. Illinoisiness affected with a public interest" tioning the government to ${ }^{66}$ was good law? In that event, petito one's firm would be to seek unlawful anticompetitive benefit government would have no power to rate action, because the matter? No. The reave no power to restrain trade. Should that tion between Noerr and it should not matter highlights a distinctrust laws. The First Amer that cannot be found in the anticitizen from any liability arising will, where applicable, protect a ernment, even if the government of efforts to petition the govto give the citizen the relief she has no power constitutionally exists apart from limitations, antitrus. That the right to petition ernment's ability to respond to petition otherwise, on the govwhich the government rond to petitioning, or the manner in based in something other

\section{Immunity After Noerr-The Search For A Theory}

The Court has explored the relationship between Parker and
Noerr immunity in two recest to clarify either doctrine In cases, which unfortunately do little Head, Inc., ${ }^{67}$ the Noerr doctrined Tube $\mathcal{E}$ Conduit Corp. $v$. Indian ticompetitive activity taking place within a defense to antion. Indian Head made polyviny within a private trade organizabuildings. According to Indian chloride electrical conduit for ble, less expensive, and less likely to its conduit was more flexisteel conduit, which was the indly to cause short circuiting than duit is one of the goods covered by standard ${ }^{68}$ Electrical conpromulgated by the Nationat the National Electrical Code, (NFPA), a private association of Fire Protection Association duit manufacturers. The

Electrical Code approved of in derogation of the constitutional right wo be "peculiar in a democracy, and perhap grievances' ... to establish a category of lawful state action government for a redress of to urge." City of Columbia v. Omni Outdoor Advertion that citizens are not permitted The Professional Real Estate Investors Court similarly relied, Inc., 499 U.S. 365, 379 (1991) take actions that operate to restrain trade." Professied on the government's power "to 65. P'ictures, Inc., 113. S. Ct. 1920, 1926 (1993). 65. Lochner v. New York, 198 U.S. 45 (1905)

with a public interest").

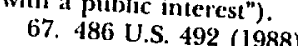

68.486 U.S. 492 (1988)

68. $l d$. at 496.

steel conduit, but not the new polyvinyl conduit. The Code was routinely adopted as law by many state and local governments "with little or no change. ${ }^{\text {"99 }}$

Indian Head therefore had a problem: in a large number of cities, it could not sell polyvinyl conduit without violating local building codes. ${ }^{70}$ So Indian Head asked the NFPA to add polyvinyl chloride to the list of materials permitted by the National Electrical Code. Allied Tube, the nation's largest manufacturer of steel conduit and a member of NFPA, was understandably distressed by the prospect of a new source of competition. So it contacted other major steel conduit producers and agreed, in the words of the Court, to "exclude [polyvinyl] from the 1981 Code by packing the upcoming annual meeting with new Association members whose only function would be to vote against the polyvinyl chloride proposal." ${ }^{71}$ The steel manufacturers recruited 230 new NFPA members, and paid $\$ 100,000$ to register them and bring them to the meeting, where they voted down the polyvinyl proposal. $^{72}$

The question in the case was whether such "lobbying" to affect the NFPA's decision was entitled to Noer immunity. Although the NFPA is formally a private association, its electrical code is adopted wholesale, and presumably without detailed (or perhaps any) deliberation, by a majority of state and local governments in the country. ${ }^{73}$ According to Allied Tube, this meant that NFPA was "akin to a legislature," were akin to petitioning a legislature. There is something to this argument. Given the detailed nature of the Code and its widespread adoption by cities and states, the NFPA was realistically the only body which could change the laws governing conduit in the United States. The alternative-to lobby each of the fifity states and thousands of municipalities that adopt electrical codes-would hardly be cost-effective. Furthermore, given their

69. Id. at 495 .

70. Furthermore, many underwriters would refuse to insure buildings not conforming to the Code, even if the local government had not adopted the Code as law. Id. at 496 . 71. Id

72. Id. at 496-97. The vote was $990-394$. The new voters were "instructed where to sit and how and when to vote by group leaders who used walkie-talkies and hand signals to facilitate communication." $J d$.

73. For a description of the widespread adoption of the Code, see Indian Head, Inc. v. Allied Tube \& Conduit Corp., 817 F.2d 988, 989 n.1 (2d Cir. 1987).

74. Allied Tube, 486 U.S. at 498 . 
would likely be unwilling to alter the Code, those governments
75 The Court was not persuaded.

ing immunity that focused on "the fashioned a test for petitionthe anticompetitive restraint at issue "76, context, and nature of this meant that the result ut issue." 76 At least in Allied Tube, trade resulted from government on whether the restraint of to ask why this should matter. same in either case-Indian. Not only would the result be the yvinyl conduit - but there is at least in be unable to sell its pol"public") review of NFPA decisions. En theory legislative (that is, tures were not undertaking a substantive if state and local legisladards, there is a good argument thative review of the Code stanof polyvinyl conduit was the adoption real restraint on the sale the NFPA Code. As the Courtoption by these governments of to accept) Allied Tube's argument "the (and largely seemed ticompetitive effect in this cament, "the lion's share of the antion of the Code into laws by a came from the predictable adopgovernments." 77 Had these a large number of state and local Code-had it been merely ad governments not adopted the bly have discounted, at least to som-the market could presumanation of polyvinyl conduit. ${ }^{78}$ By this view, the NFPA's condemtrade restraint resulted from government, at least part of the

The Court's response from government action.

lic from private actors to this argument was to distinguish pubrelative abilities to discern and the Court's perception of their Court put it, "[w]e may presume, abse public -good. As the trary, that [government] acts in absent a showing to the conparty, on the other hand, may in the public interest. A private ily on his or her own behalf "79 presumed to be acting primarbasis for the Court's decision: 75. This is true for a variety of reasons. First, they may trust the NFPA, as a group of
experts, to make the right decision. Particularly if Indian Head had already lost its fight
before NFPA, legislatures might be unwilling to second-guess that
governments might governments might see the Code as a default rule,guess that decision. Second, local changes. Finally, it would undoubtedly be difficult rule, creating a presumption against cient attention on the rather arcane subject matter to persuade legislators to focus suffi-

76. Allied Tube, 486 U.S. at 499.

77. Id. at 502 (emphasis added)

78. Of course, information costs might thwart such a process. It is possble that the cost

of obtaining good information about polyvinyl chloride and the is possible that the cost

79. Allied Tube benefit to be had by using polyvinyl chloride instead NFPA processes

7. Alied Tube, 486 U.S. at 501, quoting Hallie

[T] he decisionmaking body of the Association is composed, at least in part, of persons with economic incentives to restrain trade. ... . [W] here a restraint is imposed by persons unaccountable to the public and without official authority, many of whom have personal financial interests in restraining competition, we have no difficulty concluding that the restraint has resulted from private action. ${ }^{80}$

There is quite a lot to be said about these statements, but two points merit emphasis. First, although billed as a petitioning immunity case, Allied Tube is analytically a state action case. ${ }^{81} \mathrm{Be}-$ cause of the posture in which the case reached the Court, ${ }^{82}$ the Court did not decide the question whether the routine, uncritical adoption of the Code by states, and local governments exercising state authority, immunized both the Code and the competitors who had pushed it through. ${ }^{83}$ Nevertheless, the Court seemed to assume that adoption of the Code would confer immunity for harm caused by such adoption, regardless of the care (or lack thereof) the legislators exercised. ${ }^{84}$ Second, the Court's distinction between public and private decisionmakers rests upon a critical assumption-that the government will serve the public interest. The asserted reason for this assumption is that government officials (who either exercise or delegate power) have to account for their actions to the public. ${ }^{85}$ Should their actions stray too far from the public's own conception of its interest, this theory holds, these government officials will rapidly become ex-government officials. We will return to this assumption $^{86}$ in some detail in Part II.

80. Id. at 501-02.

81. The court of appeals had concluded that Indian Head had not sought any recovery for harm caused by the adoption of the National Electrical Code by any governmental body, and the Court took that conclusion as a given in its review. Id. at $498 \mathrm{n} .2$. The Court's broad discussion of the relative likelihood that public and private actors would serve the public interest thus seems unnecessary to the Court's decision on the issues serve the
before it.

82. Id. at 502 .

83. If the legislatures had deliberated over the Code, made such changes as they
82. Id 83. If the legislatures had deliberated over the Code, made such changes as they
deemed necessary, and otherwise taken matters into their own hands, the Court's concludeemed necessary, and otherwise taken matters into their own hands, the Court's concly-
sion could legitimately have been said to rest on the grounds that the legislators-by actively deliberating over the Code-had "cured" any bias or anticompetitive effect tha went into its promulgation. As the record stands, however, that is apparently not what happened. See id. at 502-03.

84. At least one circuit court has read Allied Tube to say just that. See Sessions Tank Liners, Inc. v. Joor Manuf., Inc., No. 92-55085 (9th Cir. February 15, 1994)(defendant immune from liability for misleading standard-setting organization into enacting an ticompetitive restriction in organization's fire code).

85. Id. at 501-02.

86. Actually, there are several assumptions wrapped up in this one large assumption. First, the Court must assume that the public can know what its own interest is. Second, it 
Advertising, Inc. ${ }^{87}$ According to Omni's view of v. Omni Outdoor jury verdicted the benefit of any doubt becaus of the facts, which ket for bill, Columbia Outdoor Advertising had Omni had won a Colur sought to acquired such a large market share mayor to keep it is a different story. According unclear. How it mayor and other members of the According to Omni, " $[t]$ he friends of [Columbia's] majority the city council were personal officers occasionally contributed fund, and the company and its to their campaigns." 89 "When Omni entered free billboard space ected some billboards of its own Contered the market and erin government to enact restrictions Columbia persuaded its friends tion that the Court enact restrictions on new billboard itsiends pete." ${ }^{\text {90 }}$ Omni sued said "severely hindered Omni's ability constructhe Sherman sued Columbia Outdoor and with Omni, Act by conspiring to restrain the city for violating

Omi, but the Supreme Court reversed ${ }^{91}$. A jury agreed Omnis importance lies in the Court'sed.

ples of Parker, which principles it expres elaboration of the princiciency valued by the Sherman it expressly elevated over the effidiscussion with a reference to "th Act. The Court began its federal system" and a citance to "the role of sovereign began its Court, stood for a citation to Parker. ${ }^{92}$ Parker, according in a commitment for the proposition that "in ligh, according to the Act sheuld to federalism, the general lan light of our national by should not be interpreted to prohibit antige of the Sherman regulators."93 in their governmental capacitietitive actions regulators." 93 their governmental capacities as sovereign

In discussing Parker, the Omni Court made three main points. process-and Columbia Outdoor's inputs into main points. the Court and their effects on the city's decisions the legislative officials put it, it is "both inevitable and dions-as good. As of agree to do what one or anotesirable that public must assume that the public ar private assume that legislators themselves, evectively police government officials. Finally it must both identify it and effectively promote it they seek to advance the pubinally, it mus 87. 499 U.S. 365 (1991)

88. $l d$. at 367 .

89. Id

90. $\frac{1 d}{2}$ at 368

91. Id. at 384

92. Id. at 370 .

far as federalism is Court explained that the city of Columbia

was delegated to it by the stared, was nonetheless entitled to imm, while not a sovereign as citizens urges upon them." ${ }^{\text {"94 }}$ Thus, Omni adopts as a partial justification for Parker the second reason provided for immunity in Noerr-the representative nature of government. ${ }^{95}$

The Court's second point was that the city was not required to adopt efficient policies. ${ }^{96}$ As the Court put it, "[t] he fact is that virtually all regulation benefits some segments of the society and harms others; and that it is not universally considered contrary to the public good if the net economic loss to the losers exceeds the net economic gain to the winners. ${ }^{m 7}$ This point is sound, as far as it goes. The question whether government should transfer wealth from $A$ for the benefit of $B$ is a political judgment, ${ }^{98}$ and thus given to the legislature rather than to judges or jurors. The point is not very helpful here, however. Omni presents a conflict of two legislative preferences-the federal preference for efficiency reflected in the antitrust laws and the city's preference for conferring monopoly profits on Columbia Outdoor. How this conflict is to be resolved depends on the role of federalism in the antitrust laws, ${ }^{99}$ a question the Court did not address in any meaningful way. The Court obviously believed that some values are more important than efficiency, and therefore trump the antitrust laws in the case of a conflict. But the Court did not make clear what those values are.

\section{Id. at 374.}

95. Omni argued that, while this might be true, there is a difference between responsive public officials and co-conspirators. Justice Stevens' dissent echoes this point. In his view, the jury's finding that the city was involved in a conspiracy was enough to remove the case from the scope of Noerr immunity. $I d$. at 398 (Stevens, J., dissenting) 96. Id. at 377 .

97. Id. This statement is perhaps a recognition of the economic truth that virtually all government-directed wealth transfers will decrease the aggregate wealth of society, both because they injure the losers more than they benefit the winners and because of transaction costs. See, e.g., A. Mitchell Pounsky, AN InTroduction to LaW \& Economics 105107 (1983).

98. But see Richard A. Epstein, Takincs: Pruvate Property and the Poher of Eminent DOMaIN (1985) (arguing that inefficient wealth transfers are constitutionally defective). 99. We must pause here for a moment to ask why the Court is concerned with federalism at all. One can argue that the Supremacy Clause takes care of the whole problem very simply: either a given state action conflicts with the antitrust laws or it does not. If it does, the state action is invalid under the Supremacy Clause. If it does not, one need not talk about federalism-the state wins on the merits of the antitrust claim. Professor Elhauge frames this issue admirably. See Einer R. Elhauge, The Scope of Antitrust Process, 104 Harv. L. Rev. 668, 669 (1991) [hereinafter Elhauge, Antitust Process]; see also Frank H. Easterbrook, Antitrust and the Economics of Federalism, 26 J.L. \& EcoN. 23, $24-25$ (1983).

Nonetheless, the Court concluded in Parker that federalism does matter. Parker, 317 U.S. at 362. We will see why in some detail when we return to the issue in Part ll. But the short answer to the Supremacy Clause point is that the state federalism interest at issue in the state action cases is of constitutional dimensions, and thus must be balanced against ine federal interest in operation of its statute without state hindrance. See supra note 24. 
The Court's third point was that determi tors conspired with private actors would rmining whether legislato inquire into the subjective would require judges and juries whether a legislator actually thoughtion of legislators-to ask interest" when it was cast 100 thought a vote was "in the public deconstruction of the governme Court found this "the sort of official 'intent' that we have contal process and probing of the This concern was greatly overstated. Thently sought to avoid."101 takes to examine subjective lated. The Court frequently underspeech, ${ }^{102}$ free exercise ${ }^{103}$ and legislative intent in the free the practice is less common and equal protection ${ }^{104}$ areas. ment of such scrutiny per se particust cases is not an indictprinciples are at stake. per se, particularly where constitutional Finally, the

nity, relying on Noerr to distinguich briefly on petitioning immuwhich the antitrust laws are conish between trade restraints, with which they are not concerned. must be protected becaused. Petitioning, the Court reasoned Court's words, "it is obviously peculion is protected. ${ }^{105}$ In the haps in derogation of the peculiar in a democracy, and pergovernment for a redress of gory of lawful state action grievances' . . to establish a cateurge." 106 As noted action that citizens are not permittedurge." 106 As noted above, this point cannot not permitted to petitioning immunity. ${ }^{107}$ The Coint cannot serve as the basis for there must be a dialogue between the focus on the concept that erned was appropriate, however. The government and the govin Part III.

\section{Omni, 499 U.S. at 377}

101. Id. at 377

102. See, e.g., Uni

ing the burning of draft cards on the ground U.S. 367 (1967) (sustaining statute prohibit suppression of speech)

103. See, e.g. Department

Exercise Crohibiting use of peyote was neurces v. Smith, 494 U.S. 872 (1990) (holdi

use peyte in as applied to a Native American and therefore did not violate (holding peyote in a religious ceremony). American church member who claimed the Fre 104. Se, in a religious ceremony).

that the Equal Protection Clause prohibienburg Bd. of Educ., 402 U.S. 1 (1971) (hotding

emographic patterns to affece prohibits only deliberate attempts by 1 (1971) (holding

105. Omni, 499 U.S. at 379 .

106. Id. at 379 .

107. See supra notes $30-31$ and accompanying text.

\section{State Action Immunity As A Federalism Doctrine}

\section{A. Essential Dissimilarity}

Both state action and petitioning the government can have severe anticompetitive consequences. Indeed, many of the very cases that established the immunity doctrines present paradigmatic examples of antitrust violations. This section considers some of the myriad ways in which state action raises anticompetitive concerns. ${ }^{108}$ Some of the examples are unquestionably antitrust violations in themselves. Others merely constitute anticompetitive conduct with which the antitrust laws are properly concerned. The two need not be distinguished here. Regardless of whether anticompetitive conduct is itself an antitrust violation, that it is protected by the immunity doctrines proves both of the points to be made: that protected conduct is not "essentially dissimilar" from conduct governed by the antitrust laws, and that the existence of the immunity doctrines has anticompetitive consequences that should be considered in deciding whether to invoke those doctrines in particular circumstances. ${ }^{109}$

Governments act in anticompetitive ways all the time. Indeed, to the extent one considers market ordering to define the true competitive state of affairs with respect to any given product or service, government; which largely redistributes market allocations of resources, is necessarily anticompetitive. Governments from time to time create monopolies expressly by passing laws that prevent more than one company from competing in certain markets. Electric power, gas transmission, and local telephone service are three obvious examples. ${ }^{110}$ More recently, cable televi-

108. The anticompetitive characteristics of petitioning are discussed infra section III.B. 109. We operate throughout under the assumption that the battle for the "soul" of antitrust, see Elanor M. Fox, The Battle for the Soul of Antitrust, 75 CAL. L. Rev. 917 (1987), is over, and that the economists (if not the Chicago School) have won. But see Eastman Kodak Co. v. Image Tech. Servs., Inc., 112 S. Ct. 2072 (1992); but see again Brooke Group, Ltd. v. Brown \& Williamson Tobacco Corp, 113 S. C. 2578 (1993). However, that as sumption is not essential to our argument. Readers who believe that the purpose of the antitrust laws is to protect competitors rather than competition, or even to prevent "bigness" in all its forms, as some have suggested, (see, e.g., United States v. Trans-Missouri Freight Ass'n, 166 U.S. 290 (1897); Elanor M. Fox \& LnRry Sulurvan, Cases and MaterlALS ON ANTTTRust 93-37 (1989); Robert H. Bork, The Role of the Courts in Applying Economics, 54 ANTrTRust L.J. 21, 24 (1985) (collecting cases and commentators); Victor H. Kramer, The Supreme Court and Tying Arrangements: Antitrust as History, 69 MinN. L. REv. 1013 (1985)), will no doubt find the conduct we describe here equally problematic.

110. See, e.g., Federal Power Act, 16 U.S.C. \$ 791a et seq. (1988); Natural Gas Act, 15 U.S.C. $\$ 717$ et seq. (1988); Communications Act of 1934,47 U.S.C. $\$ 151$ et seq. 
Governments also grant monks of these "utility" monopolies. ${ }^{111}$

a lesser extent, to holders of other intellecters of patents and, to

These government-granted mon intellectual property rights. ${ }^{112}$ cial purposes. Utilities, for examplepolies may have laudable soexamples of "natural monopolies" in which cited as paradigm tion is preferable to free competition which government regularights are designed to promote innovation ${ }^{.13}$ Intellectual property reward in the market without suffering firms that did not incur the inventor's competition from copycat ernments need not have such laudabs start-up costs. ${ }^{114}$ But govtheir monopoly grants. The original social purposes behind designed to provide monopolies to patent statutes were cials, not to promote innovation 115 friends of government offimade clear, regulated movation. ${ }^{115}$ Moreover, as the courts have Finally, governments often polies still present antitrust issues. ${ }^{116}$ tries that exceed the scope of thenopolies to regulated indushave obtained on their own. 117 natural monopoly they would

Monopoly is the very evil the anti111. See, e.g., Turner Broadcasting System v. FCC, 819 F.Supp. 32 (D.D.C. 1993), cert.
granted 114 S. C. 38 (1993) (Supreme Court to revis

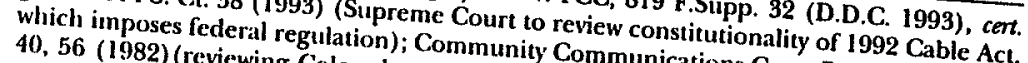
112. 35 U.S.C. $\$ 154$. As corado municipality's regulation of cable. Boulder, 455 U.S. does not always (or even commentators have noted, an oxclubive television).

See, e.g., Nat'l Inst. on Indus. \& translate into a monopoly in a relight to work a patent Protected Rights, 53 ANTrTrust \& Intellectual Prop., The Value of Patevint product market nomic Irrationality of the Patens L.J. 535, 547 (1985); Mark A. Lem Patents and Other Legally William Montgomery, Note, The Presumpine, 78 Cat.. L. Rev. 1599 , Comment, The Fco Products in Tying A man Note, The Presumption of Economic Pow. 1599, 1627 \& $\mathrm{n} .181$ (1990) some cases, however. Others, 85 Con.um. L. REv. 1140,1156 (1985). Ited and Copyrighted 17 U.S.C. $\$ 106$, 113. See, e.g. Roce also create product monopolies in provided by the copyright laivs,

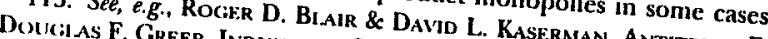

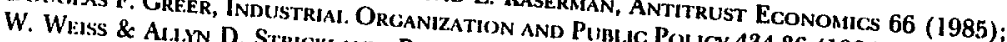
114. 114. See Louis Kaplow, The Patemt-Antitrust Intersection: A Reappraisal 97 (1982).
1813, $1817-18$ (1984). 115.

The F. See Darcy v. Allen, 11 Coke 84b, 77 Engepraisal, 97 Harv. L. Rev.

The English Common Law Concerning Monotolies. Rep. 1260 (K.B. 1603); William Le

Minda, The Common Law, Labor, and Antitrust, 12 INDUs. REI. REv, 355, 359 (1954); Gary still subject to the dictates of theit Edison Co., 428 U.S. 579.595 (1971, 477-79 (1989).

U.S. 366, 373 (1973) (power the antitrust laws); Otter Tail Power Co. v. United St utilities Xerox Corp., 645 F.2d 1195, 120406 (2nd exempt from antitrust laws); SCM Cortes, 410 antitust scrutiny); United States (D.D.C. 1981)(successful governmerican Tel. \& Tel. Co., 524 F. Supp. 1396 monopoly). $\quad$ government antitrust suit against regulated 1336, 1371-72 117. Cantor, 428 US, at 58284 is aginst regulated telephone endorsed a Detroit Edison "lightbulbexchange" program
Edison supplies "free" case, the state of Michigan only, however. By aggregating the cost of lightbulbs with the cost bulbs were free in name

trust laws seek to prevent. Government-granted monopoly may be efficient in some cases, but government power to grant monopolies presents substantial competitive risks, particularly if such grants are immune from antitrust scrutiny. ${ }^{118}$

Governments also will at times form or support private cartels. Unlike regulated monopolies, which are generally imposed for economically defensible reasons, the justifications for government-supported cartels range from dubious to nonexistent. Governments have restricted or eliminated entry in markets ranging from air travel ${ }^{119}$ to legal services ${ }^{120}$ to raisin farming. ${ }^{121}$ The result of such government action is to give cartel participants a legal means to enforce the cartel. This makes cartels much more stable, and further undermines the competitive tendencies of the market. ${ }^{122}$ Other government actions may produce similar effects by setting price floors rather than restricting entry. A number of states have passed mandatory minimum resale price maintenance laws that fall into this category. ${ }^{123}$ For maximum anticompetitive effect, states may combine price floors with restrictions

had become a monopolist in the otherwise competitive lightbulb market, and could charge whatever price it wanted for lightbulbs (subject only to regulatory approval).

118. Not the least of these risks is that firms will waste resources petitioning the government for such monopolies. The expenditure of resources to chase inefficient outcomes is itself inefficient, and is properly counted as a cost of monopoly. See POSNER, EcONOMIC Perspective, supra note 2, at $11-12$.

119. See Civil Aeronautics Act of 1938, 49 U.S.C. $\$ 401$ et seq. (repealed 1978).

120. In Goldfarb v. State Bar, 421 U.S. 773, 776-78 (1975), the state of Virginia through the state and local Bar Associations not only limited entry into the legal market, but set a minimum price schedule for legal services. The Court held the fee schedules constituted price-fixing in violation of the Sherman Act. Id. at 776-78. Similar governmentenforced legal cartels nevertheless remain common in most states.

121. See Parker v. Brown, 317 U.S. 341, 350, 359 (1943) and discussion thereof supra at
low section I.A.; see also Harold Pfaff, Organic Farmer Says the State Plows Into Her Field of Dreams, S.F. DAILY J., Oct. 1, 1993, at 1 (reporting that the San Joaquin Valley Cotton Board, which is dominated by industry officials, sets production limits for cotton in California under state law).

122. Cartels extract monopoly rents by agreeing to reduce total output and raise prices to the monopoly level. Thus, a cartel is more profitable than an oligopoly. GreEr, supre note 113, at 263. Cartelists have a strong incentive to cheat on the cartel by expanding output, however, because if only one cartel member cheats, it can increase its profits dramatically. See BLAR \& KASERAAN, supra note 113, at 141-45 (documenting this probfirst, POSNER, Econosic PERSPECTIVE, supra note 2 at $52-54$ ber has an incentive to chea prisoner's dilo classic prisoners dilemma. Se ROBERT COOTER \& THOMAS ULEN, LAW AND ECONOMICS 93 \& $n$.3 (1988). A government-sponsored cartel can overcome this problem by using the legal process to enforce the cartel. Cartels with government backing are, therefore, a far more potent anticompetitive weapon than purely private cartels

123. See, e.g., 324 Liquor Corp. v. Duffy, 479 U.S. 335, 343 (1987); Schwegmann Bros. v. Calvert Distillers Corp., 341 U.S. 384, 386-87 (1951) (both considering such statutes). Rent control ordinances may have similar (albeit less direct) effects. Indeed, the City of Berkeley's rent control ordinance was (unsuccessfully) challenged as illegal price-fixing
by the government in cooperation with renters. Fisher v. City of Berkeley, 475 U.S. 260 
on entry or production, as California did in supporting its raisin
cartel in Parker. ticompetitive, and the policy justification results are undeniably anfor professionalism ${ }^{125}$ and to avoid "dons (for example, the need are generally inadequate.

The government also in

to new entry. Such barriers generally markets by creating barriers regulatory barriers may prevent new entry, one of two forms. First, expensive, or limit its effectiveness. ment restricts new entry, preventing it in state licensing requireing temporal and financial constraints in some cases and imposprofessions are a good example, ${ }^{127}$ but in all cases. The medical ernment require licensing in numerous diffes and the federal govcensing is at its worst when those who defferent industries. Lithe licenses are themselves compe decide whether to approve practice is quite common in the profession in the industry. This are presumably best suited to know whether, where competitors "qualified" to enter. ${ }^{128}$ to know whether a potential entrant is Regulatory "barriers"

uct approval. Entry into the U.S. pharmaceutical delays in prodample, is rendered far less attractive by the preal industry, for exand Drug Administration, which may the presence of the Food product for sale. ${ }^{129}$ During that time take years to approve a new erating expenses and the costs of pursuing company incurs opreceives no benefit. The drawn-oursuing FDA approval, but larger firms, which can better afford FDA process favors both puch long-term Sup. CT. Rev. 157. 124. Parker, 317 U.S. at 359

125. Compare Goldfarb 359 .

entitled to restrict "demoralizing" Bar, 421 U.S. 773, 792 (1975) (holding that a sate of Prof. Engineers v. United States, 435 U.S. 679 in legal profession) with National Soc'y group cannot assert a similar justification).
126. See Part Pror. See Parker, 317 U.S. at 355 ("It]he dect

affecting' the market" and excessive supplies of agricultural commoditien [Agricultural and maintaining prices") 127. See, e.g., Williams.").

restricting entry into the $v$, Lee Optical Co., 348 U.S. 483, 486 (1955) (Otlats raising 128. See, e.g., Goldfarb eye care market).

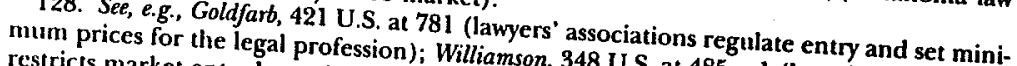
restricts market entry by opticians); cf. Parker, 317 U.S. at 347 ( $485 \mathrm{n} .1$ (board of optometry ers to control board regulating raisin production).
129. See, 347 (statute entitles raisin farm129. See, e.g., Reginald Rhein, BIO Circulates Oret

deal with them); James, July 5, 1993, at 1 (noting FDA delays and on Capitol Hill, Bro. 1993, at A1 (noting criticism by medices Languish in FDA Limbo, L.A. TimEs, April to

benefits, and entrenched firms, which have already-approved drugs in the "pipeline" to help defray costs. ${ }^{130}$

Finally, trade quotas are powerful regulatory barriers in international markets. ${ }^{131}$ Unlike tariffs, quotas limit the number of foreign goods of a particular type that may be imported in a given year. Quotas thus pose a powerful barrier to foreign entry, both because foreign market share is artificially limited and because low quotas may deter foreign firms from entering at all or from spending advertising resources on a comparatively small U.S. market. ${ }^{132}$

A different form of government-imposed barrier to entry protects favored firms by raising their rivals' costs. ${ }^{133}$ For example, many governments have enacted "prevailing wage" statutes, which require companies to pay a certain wage to their workers. ${ }^{134}$ Such statutes protect firms that use higher-priced union labor, at the expense of their non-union competitors and of consumers. The statute that rendered the union conduct immune in United Mine Workers $v$. Pennington ${ }^{135}$ was a prevailing wage statute. ${ }^{136}$ Tariffs are another good example. Just as a quota served as a partial barrier to entry, so tariffs raise the costs to foreign

130. To be sure, most pharmaceutical companies probably do not think of the labyrinthine FDA process as a "benefit" to them. It is true that they would be able to produce new drugs far more quickly and cheaply absent any regulation at all. Our point, however, is that potential entrants are hurt worse by the FDA rules than existing firms. To that extent, existing firms receive a relative benefit, however diffuse.

131. Barriers to international trade are a venerable political tradition, and are in fact enshrined in the United States Constitution, Art. I, \$ 8, cl. 1, 9. The significance of such barriers is growing dramatically, however, as the importance of international markets to domestic consumers and industries increases. See JAcDISH N. Bhacwati, Protectionism 43-50 (1989); Thomas M. Jorde \& David Teece, Innovation, Cooperation, and Antitiust: Bal. ancing Competition and Cooperation, 4 HiGH TECH. L.J. 1, $39-34$ (1989).

132. See, e.g., Bhacwati, supra note 131, at 7-9 (trade barriers such as quotas reduce gross national product, all other things being equal); Ruchard E. CAvEs \& RonALD W. Jones, World Trade AND PAYMents 212-14 (1985) (trade restrictions make imposing na-
tion worse off); James Bovard, America's Biggest Trade Secreh L.A. Times Mac., April 12, tion worse off); James Bovard, America's Biggest Trade Secreh, L.A. Ttmes MAc., April 12, 1992 , at
year).

year).

While all trade barriers are inefficient, quotas are unquestionably inferior to tariffs. A tariff takes money from ultimate domestic consumers and puts it into the domestic treasury. Quotas take money from American consumers and give it to foreign firms in the form of higher prices. Paul Samuelson, Economics 635 (1980)

133. Raising rivals' costs can be an effective way to obtain limited monopoly power. See Thomas G. Krattenmaker \& Steven Salop, Anticompetitive Exclusion: Raising Rivals' Costs to Achieve Power Over Price, 96 YALE L. J. 209, 214 (1986).

134. See, e.g., Walsh-Healey Act, 49 Stat. 2036, 41 U.S.C. $\$ 35$ et seq. (1958)(establishing prevailing wage for government contracts).

135. 381 U.S. 657 (1965).

136. $I d$. at 660 . 
and U.S. consumers lose out. ${ }^{137}$ Finally, firms benefit; foreign firms

pants, buying or selling non-public time act as market participrivate firms. States acting in such a capacity in competition with cartelize, predate, or otherwise act just as acity may monopolize, private firm. Examples abound, but a few anticompetitively as any Maine recently passed an ordinance rew should suffice. A city in solid waste be treated at the facility run requiring that recyclable corporation that it owned, rather than run by a public non-profit private facilities. ${ }^{138}$ Government agencies ther of two competing purchasers of a particular commodity mat that are the principal power ${ }^{39}$ to reduce prices below the competitive their monopsony terms and conditions on sellers, ${ }^{140}$ or to favoritive level, to impose the expense of out-of-state companies. ${ }^{141}$ Similacal businesses at such grant exclusive franchises for use of such as arenas and airports, and in use of government facilities sions themselves. In either, and in some cases operate concesexclude the competition. ${ }^{142}$ case, the government acts by fiat to

The state action doctrine

private enterprises that lobby them froth governments and the tive government conduct, without rem liability for anticompetifor competition or the legitimate regard to the consequences

of the antitrust

138. Tri-State Rubbish, Inc. v. Wasteterious effects of protectionism)

1993) (immunizing the city ordinance from anagement, Inc., 998 F.2d 1079 (loctrine) v. Wrom antitust, Jnc., 998 F.2d 1073 (lst Cir.

139. Monopsony refers to the power an state action of monopoly.

140. Some obvious examples of Department of Defense, which of government monopsony power are the which may limit the sales to which faces competition only from foreige the United States federal power authorities like governments in the interests of "natgerenments and Administration, which may pure Tennessee Valley Authority of "national security," and Sitenz v. University Interscho purchase power from outside their and the Bonneville Power standard for books and supplies League, 487 F.2d 1026 (5th Geographic limits. See also 141. See, e.g. Hug and supplies to be purchased). 141. See, e.g., Hughes v. Alexandria Scrap Corp).

they used Maryland prash to citizens who scrapped a.S. 794 (1976) (upholding Mary142. Such actiond processors). Compare Duke \& Co. v. Foerster place and have elicited mixed reactions from franchise for the sale of beer on 521 F.2d 1277 (3d Cir. 1975) (overtions from the courts. (D.C. Cir. 1971) (holding a on city property) and Hecht v. Pro-Foothang an exclusive with Ladue Local Lines a football team's grant of exclusive use of sall, 444 F.2d 931 city's exclusive franchise for local bus. Agency, 433 F.2d 131 (8th Cir. 1970) (uphlawful) Wiggins Airways v. Massachusets Port Ausportation, which excludes competitorsing exclusive franchise for the sale of cort Auth., 362 F.2d 52 (1st Cir. 1966) (approsing and laws. ${ }^{143}$ The Supreme Court has made it more expensive for states to act anticompetitively by immunizing only anticompetitive conduct in which the government takes an active role, ${ }^{144}$ and it has provided less protection for local governments and those who seek to influence them. ${ }^{145}$ In the main, however, governments can and do act in ways the antitrust laws would roundly condemn in other circumstances.

Before leaving this point, one qualification must be added to this conclusion. The authors take the goal of the antitrust laws to be the enhancement of consumer welfare. Much ink has been spilled over whether this is or should be considered the proper goal. But the resolution of this particular debate does not matter here. Even if one were to consider the antitrust laws as designed to protect Justice Brandeis's (really Justice Peckham's) small dealers and worthy men, ${ }^{146}$ one still would have to compare the effects of state and private competitive restraints with reference to that goal. There is no reason to believe state action would be deserving of more or less antitrust scrutiny under any alternative goal.

For example, if one were to favor the protection of small dealers as an antitrust policy one would tend to favor the creation of cartels. ${ }^{147}$ Cheating is the bane of private cartels because mem-

143. See, e.g., Pennington, 381 U.S. at 663 (upholding government-imposed price constraints in labor market); Parker v. Brown, 317 U.S. 341, 350-51 (1943) (upholding statesponsored raisin cartel)

144. California Retail Liquor Dealers Ass'n v. Midcal Aluminum, Inc., 445 U.S. 97, 105 lated" state policy and be that an anticompetitive state restraint be both "clearly articunia's resale price maintenance scheme for wine producers because it was insufficiently supervised.

145. See Lafayette v. Louisiana Power \& Light Co., 435 U.S. 389, 412 (1978) (municipali-
145ervised. ties are not automatically immune under Parker because they are not state actors). The Supreme Court has recently been more generous in protecting anticompetitive actions taken by local governments, however. In Hallie v. City of Eau Claire, 471 U.S. 34, 39-41 (1985), the Court held that cities are immune from antitrust scrutiny even if they act pursuant to an unsupervised state policy, as long as it is "clearly articulated." And in City of Columbia v. Omni Outdoor Advertising, Inc., 111 S. Ct. 1344, 1351-55 (1991), the Court held that both cities and private parties are immune from antitrust liability even if they conspire together to benefit the private party.

146. Justice Peckham's reference came in United States v. Trans-Missouri Freight Ass'n, 166 U.S. 290, 323 (1897), and was picked up by Justice Brandeis in Chicago Board of Trade v. United States, 240 U.S. 231, 238-39 (1918). For a discussion of the different usages of this term by the two Justices see Bork, Antitrust Paradox, supra note 6, at 25, $41-46$.

147. This is because cartels raise the price of the cartelized product above the competitive level, providing a form of price cover for relatively inefficient firms, which by hypothesis could not price at the competitive level. See Posner, Economic Perspectrve, supra note 2, at 160 . This leaves open the possibility that small dealers could suffer from limit pricing by cartelists, who might give up some of their monopoly profits to eliminate com- 
If exeryone output in order to capture sales from prices marginally and itive level, cheats, the price is eventually reduced their competitors. police cheating all the cartelists lose out. Because the competing enforceming better than the cartelists themse the state can vestorcement mechanisms such as adminiselves-by throwvestigators, police, and the courts as administrative agencies, inwork better than private ones. But that the cartel-state cartels ating more state cartels, it would that would argue only for creguishing between state and private cartels forde a basis for distinIf the antitrust laws sought private cartels for antitrust purposes cartel and a forms sought to protect small firms, both purposes. immune from formal state cartel like the one ins, both a private siclerect a som antitrust scrutiny. The private in Parker would be ers, who second-best option because it would cartel would be concompetitive prichreaten small business by selling more cheatfellow carive price in an effort to steal businelling closer to the fellow cartelists. But the cartel still would business away from their trust scrutiny.

This pat

provides a strong clue that the the range of antitrust issues. It actors may be immune for the answer to the question why state could go to jail for necessarily lies outse things private actors the very least, the answer cannot be foude the antitrust laws. At similarity" in purpose or effect between found in any "essential distors and the sorts of conduct been the conduct of state acprevent. ${ }^{148}$ sorts of conduct the antitrust laws mean to

\section{B. Explaining the State Action Doctrine} The previous section establishes that the effects of legislative
action are in fact essentially similar to the effects of pricompetitive action. state action action. One thus must look effects of private anples of federalisunity. The Court's repeated refere to explain answer lies in solin Parker and cases following it answer lies in something inherent in following it suggest that the posing the restraint.

pecitors. Of course, this worry is ensy to ex are by ly

are by hypothesis inefficient; to "predate" against them the competitors we speak of here
the competitive level. 1.48. Professor bill

the state action doctinge offers a third possible dissimilurity,

mental and private restraints of traty grounds-a dissinilarity in proch believes explains

This view has been disputed by several commentators, most notably Professors Wiley and Elhauge. This section steps back for a moment from the cases and the economics of state action and examines the theoretical implications of the two variables with which the Court and the commentators are wrestling in these cases-the definition of the public interest and the different ways that interest may be pursued by public and private actors.

\section{The Public Interest, the Public-Private Distinction, and Public Choice Theory}

Although the state action cases have inspired numerous theories and articles, for this Article's purposes, two commentators' critiques are particularly pertinent-the "capture theory" espoused by Professor Wiley and the "process theory" of Professor Elhauge. Professors Wiley and Elhauge begin their respective works from some common ground. Neither is satisfied with an explanation of the state action cases that focuses on whether the restraint of trade at issue was actually imposed by the state or by some private actor. Both authors thus reject federalism as a basis for state action immunity. ${ }^{149}$

Professor Wiley argues that a federalism-based theory is "vulnerable to a logical attack resembling the one that has been leveled at the constitutional public-private distinction." ${ }^{150}$ Professor Elhauge expands on the point, arguing that "the principal problem" with distinctions between state-imposed restraints and privately-imposed restraints

is the absence of formal grounds for satisfactorily determining which exercises of authority created or enforced by the state should be deemed state action and which should not. Every restraint resulting from the exercise of such authority cannot be viewed as state action immune from antitrust review, for whenever businesses restrain trade they are exercising author-

Professor Elhauge rejects a theory based on a distinction between state and private action because "the existence of any determinate formal public-private distinction seems dubious in light of the rich literature establishing the formal incoherence of such

\footnotetext{
149. Elhauge, Antitrust Process, supra note 99, at 680; Wiley, Capture Theory, supra note

150. Wiley, Capture Theory, supra note 36 , at 731 .

151. Elhauge, Antitrust Process, supra note 99, at 680.
} 
distinctions in other fields of law." 152 Both authors cite Professor Elhauge adds some of the on state action, ${ }^{153}$ and Professor emerging Legal Realist movement, articles from the thenrules were not nutral, movement, arguing that common law fected by those rules could be considistribution of resources ef

Having thus disposed of considered state action. ${ }^{154}$ sors Wiley and Elhauge set the Court's stated rationale, Profesent theories. Professor Wiley first develop their own very differwhat Mancur Olsen called the "lopularized the application of the antitrust state actiled the "logic of collective action"155 to groups, which enjoy relatively high ${ }^{156}$ This logic holds that small given profitable action, members have relatively low outmaneuver larger groups, whose legislative benefits disprow per capita interests, and thus gain ral size. ${ }^{157}$ disproportionate to the small group's electo-

According to this theory, larger groups suffer mor "free rider" problem than do smaller groups suffer more from the a member obtains for the group will be because any benefit group and not just the member. The whe shared by the whole ory is that the most rational course The problem posed by the thegroup is to wait for other group for each member of the large for the whole group. Each member mers to obtain the benefit benefit without effort, taking a free believes she will obtain the Small groups have a relatively free ride on the efforts of others. lem because each member has morer time overcoming this problative action worth $\$ 100$ obtainable at stake. ${ }^{158}$ Imagine a legiseither of two groups, one of twenty. Any member of the first members and the other of 152. Id. at 681

-

PA. L. Rev 1296 , State Action and Liberal Theory: A Casenote on Fag 154.

155. See Olson, supra note 43, supra note 99, at 680 n. 61.

156. See O1.SON, supra note 43 ,

157. Id. at 724-25. Theory, supra note 36.

157. Id. at 724-25

lem as being that "individual members lin a slightly different way-he describes the probbecause participation is personally costly and co incentive to participate lin rent seeking successful joint action." Wiley, Capture Theory, contributes little to the group's chances for be slightly misleading. The effect an individ, supra note 36, at 724. This statement for group's success in obtaining some benefit is relevanember has on the probability of the as it affects the member's expected return from her to the member's choice only insofar

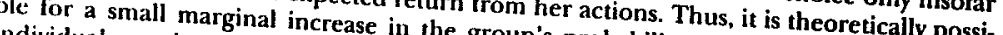
individual member to take action. cause her share $(\$ 10)$ will exceed her cost in obtaining it $(\$ 8)$, while no member of the second group will do so, because the cost $(\$ 8)$ exceeds the benefit (\$5). Even if the member of the smaller group does not want to go it alone (because then she would profit $\$ 2$ while the other nine members received $\$ 10$ ), her cost in coordinating the efforts of the other members of the group, or billing them for her efforts to obtain the benefits, will be lower than the costs facing the group with 20 members. The same logic applies when we ask where the $\$ 100$ comes from. Maintaining our $\$ 8$ assumption for the cost of transacting with the legislature, the small group will be able to make the large group pay the $\$ 100$ because it would cost each member of the larger group more to fight the small group than simply to pay up.

For Professor Wiley, this logic carries profound implications for the antitrust state action doctrine (and indeed the Court's treatment of state economic regulations generally). The gist of the problem is that collective action logic implies minority rule. More specifically, the logic implies exploitation of consumers, whose interests tend to be relatively broad and diffuse, by producers whose interests in particular regulation are relatively more concentrated. The mechanism for exploitation Professor Wiley denominates "capture," a term he uses to signify that "regulation typically benefits private interests at the expense of the consuming public." 159 Professor Wiley believes the Court has given anticompetitive state actions greater scrutiny since Parker because it is more aware of the dangers of capture than it used to be. ${ }^{160}$ Wiley endorses this approach, concluding that the Court ought to analyze state regulations for signs of producer capture, applying stricter scrutiny when those signs appear than when they are

159. Wiley, Capture Theory, supra note 36, at 724. Professor Wiley's use of "capture" is slightly different than the usual use of the term in the political science literature, though the two are related. In political science terms, capture is generally used to describe regulated industry's dominance of the entity charged with regulating it. The term there encompasses such things as institutional expertise, superior information, and the like. See genetally LAWRENCE DODD AND Richard L. SCHOTT, CONGRESS AND THE ADMINISTRATIVE STATE 178-184 (1979). Of course, the success of a regulated industry at such endeavors, in the face of at least potential competition from consumers for the agency's attention, may be and frequently is explained in collective action terms. See OLSON, supra note 43, at 147, 166 (comparing "generous regulatory policies" obtainable by business lobbies with collective action problems for consumers, who, despite being "as numerous as any other group in society ... have no organization to countervail the power of organized or monopolistic producers").

160. Wiley, Capture Theory, supra note 86, at 727-28. 
itself er his theory, it is clear that Wiley believestify the justificacome bias against public choice- the Sherman Act publicnds. ${ }^{162}$ To avoid the confusion supposetype behavior he public-private distinction, Professor Wiley sugedy created by the for distinguishing "public" from "priva" suggests three criteria antitrust liability. ${ }^{163}$ "public" from "private" action for purposes of

There is much in Professor Wiley's approach to discuss, start-
ing with the somewhat disturbing suggestion scrutinize legislation on brought the inevitable charge that grounds, which quickly ing the resurrection of Lochner-style Professor Wiley was advocatother hand, "capture" maynerstyle judicial activism. ${ }^{164}$ On the havior, and turning a blind in fact explain much regulatory befying solution. ${ }^{165}$ Both judicial to the problem is not a very satissuggest serious flaws in democial activism and regulatory capture suggests that the former may be usocesses. Professor Wiley thius effectively become a pro- used to cancel the latter, and Professor Wiley introduced his capture instrument. ${ }^{166}$ Since opinion has lent some support capture theory, the Court's Ticor

161. Id. at 743. Professor Wiley sugtests fon whether the the product of capture, and thus a for determining whether a given trust exer regulation restrains market and thus a candidate for heightener a given rectly to a tion (al for labor unions or insuly, whether it is protected by a fed scrutiny: the decisiontial market inefficiency, and whether the regulation federal antithe decisive political action of financially, and whether the regulation was responds di162. Thus Professor Wiley dispuncially interested firms in the regulated produced by actions with public choice characteristicse charge that increased judicial market. Id. unlike Lochner, Congress could amend thics will lead to a new Lochner era beview of state actions displaying public choice tend the Shernan Act to make it more by arguing that, 163. II. at 773-76. Drawing tendencies. Id. at 779 . with vesting the stie aciung on Professor Brest's wort

any obvious or rational fouses on a federalism rationale is argues that the problem unclerlying policy reanl foundations; instead each such dis that "such distinctions lack tion made by the stute as. Because no policy reason existstinction must be justificd by 773. The three criteria Pron doctrine, that distinction lists for the public-private distinc(1) provide those a forcement, those absent policy reasons: "fairness to overcome this problem are intended 16-. suue

Matthew J. Spitzer Capture Theory, 61. Antitrust Federalism and Rational of Legislation, 1987 DUKE L. J. 618; sensitive to this c1 S. CAt.. L. REv. 1293 (1988). Indeed Political Economy: A Critigue of Capture theory, supurge that he attempted to pre-emed, Professor Wiley was sufficiently Gitrind. Sheory, supra note 36, at 779. He expanded on it in his original article, Wiley, (1289-90 (1987).
105. Wiley, Jr. Revision and Apology in Antitrust Federalism 96 Ysponse to Mr.

165. See Wiley, Capture Theory, supra note 36 , at 740 .
166. See id. at 779 . capture have led the Court to scrutinize regulation for signs of capture effects. ${ }^{167}$

As a description of what the Court is actually doing in the state action cases, however, Professor Wiley's theory has little to commend it. The strong statement of immunity in Omni plainly indicates that the Court does not care whether a given governmental action could be described as the product of capture. After all, a jury in Omni had determined that the regulations at issue in that case were the product of a conspiracy between the City and Omni, a finding which certainly implies a form of capture, yet the Court held that the regulation was absolutely immune from scrutiny. ${ }^{168}$ The Court's approval of the price-fixing schemes at issue in Southern Motor Carriers Rate Conference v. United States ${ }^{169}$ similarly calls into question the idea that the Court is intolerant of regulations produced by "capture."170

Professor Wiley's theory is disturbing as a normative matter as well. Capture theory has a broad reach. Under its premises, strictly applied, all legislative action is suspect to some degree. Professor Wiley's application of capture theory would subject a state's actions to antitrust scrutiny so long as they were the result of the "decisive political efforts of producers who stand to profit from its competitive restraint." ${ }^{\text {"171 }}$ Setting the problem of conflict with the antitrust laws to one side for a moment, an anticompetitive restraint proposed by a private party might be a good idea in the eyes of some people. ${ }^{172}$

Professor Elhauge challenges a substantial amount of Professor Wiley's theory in a more comprehensive treatment of the antitrust state action doctrine. ${ }^{173}$ Professor Elhauge's project is in fact revolutionary. He aims to reconceptualize the purpose of the antitrust laws in an entirely new way, while bringing a new coherence to the state action doctrine as well. His theory is both descriptive-it aims to explain existing state action decisions-and normative-it suggests that what Professor Elhauge describes as the current approach is also the correct one. We believe Profes-

\footnotetext{
167. Federal Trade Comm'n v. Ticor Title Ins. Co., 112 S. Ct. 2169, 2176 (1992). 168. Omni, 499 U.S. at $369,384$.

169. 471 U.S. 48 (1985).

170. For additional cases illustrating this point, see Garland, supra note 47 , at $490-98$. 171. Wiley, Capture Theory, supra note 36 , at 743 .

172. Where the state manifests its adoption of such a policy and puts the force of its governance capacity behind it, principles of federalism also come into play. We discuss these issues in more detail in section II.C.

173. See Elhauge, Antitrust Process, supra note 99, at 717-29.
} 

sor Elhauge's efforts are ultimately unsuccessful, but working
through them yields several valuable insights.

trine may be found in the the source of the state action doctends that there is no conflict laws themselves. ${ }^{174} \mathrm{He}$ conregulation and the federal antitrust been anticompetitive state gues that if a conflict truly exists the laws. Professor Elhauge arbecause the Supremacy Clause comma very interesting issue, resolved in favor of the fedause commands that the conflict be Professor Elhauge works backwards. ${ }^{175}$ To show compatibility, state action immunity as evidence" He "takes the existence of tween state regulation and federe" that there is no conflict beines the contours of state action immust laws, and he examnature of the underlying antitrust ideals."176 "for insights into the state action immunity leads Professor E." antitrust law does not nomically inefficient restraints of proposition that all ecoagainst the public interest more limited proposition thather, antitrust stands for are cially from restrainsition that those who stand to profit the which rom restraints of trade cannot be stand to profit finanwhich restraints are in the cannot be trusted to determine not. ${ }^{177}$ the public interest and which are

Professor Elhauge's theory does a fairly good job of describing a portion of what the Court is actually good job of describing fortunately, much of the descriptive doing in these cases. Unfrom his definitions instead of hive force of his theory derives theory essentially incorporates the analysis. Professor Elhauge's criticizes under a different rubric "Sublic-private distinction he terested-accountable action" and "private action" becomes "disinested, profit-motivated action." As Profe action" becomes "intersubsequent article, "[p]rivate decisionsor Elhauge put it in a shorthand for financially interested decisiong' is thus merely a decisionmaking' is a shorthand for decisionmaking, and 'public cially disinterested and politically accountabloking that is finan174. See id at 696 " "The anterpe court will whenever a financially disinterested and petive restraint is immune from antitrust liant a substantive decision in favor of the politically accountable actor controtust liability the principle that financiavor of the terms of the restraint. that further the public inty interested parties cannot be trus. [A]ntitrust law embraces 175. Elhauge, public interest."). 176. Id. at 671 .
17titust Process, supra note 99, at 669 .

177. $I d$ at 672

178. Einer $R$.

1177, 1197 (1992) [hereinafter Elhauge, Petitioning Petitioning Immunity, 80 CaL. L. Rev. stay the hand of antitrust laws in cases where a restraint was imposed by a state government. Because of his definitions, Professor Elhauge's theory will lead him to the same result.

Professor Elhauge's theory and the Court's opinions differ, however, in their treatment of restraints created by municipal governments. Professor Elhauge's theory strongly implies that a municipal government restraint should not be subject to antitrust liability if the restraint was imposed by disinterested and accountable actors, a conclusion that cannot be squared with the caselaw. Professor Elhauge attempts to explain this anomaly by suggesting that municipal regulations might have anticompetitive effects outside the geographic boundaries of the governmental entities imposing the regulations. ${ }^{179}$ Consumers outside a city's limits have no power to hold the city's actors accountable for their acts. ${ }^{180}$ This problem does not exist at the state level, he contends, because (notwithstanding Parker) the Dormant Commerce Clause serves to guard against anticompetitive interstate regulations. Professor Elhauge argues that the antitrust laws should be used to achieve the same result with respect to intrastate restraints. ${ }^{181}$

This argument has some very interesting implications for the normative portion of Elhauge's theory, as noted below. ${ }^{182}$ For now, however, it is enough to note that the Court's stated reasons for denying immunity to municipal restraints have nothing to do with the risk of anticompetitive effects spilling over outside a given jurisdictional boundary. In discussing the Parker line of cases, the Court has said that "the Parker exemption reflects the federalism principle that we are a Nation of States, a principle that makes no accommodation for sovereign subdivisions of states."183

From a normative perspective, the contention that the antitrust laws themselves distinguish between restraints imposed by disinterested (public) actors and profit-motivated (private) actors is flawed on several levels. Professor Elhauge's process-based approach shifts the focus of the antitrust laws away from the eco-

179. Elhauge, Antitrust Process, supra note 99, at 732.

180. As Professor Elhauge notes, the Court emphasized this point in City of Lafayette v. Louisiana Power \& Light Co., 435 U.S. 389, 406 (1978). Elhauge, Antitrust Process, supra note 99 , at 733 .

181. Id. at 730

182. See infra notes $184-187$ and accompanying text.

183. Community Communications Co., Inc. v. City of Boulder, 455 U.S. 40, 50 (1982). 
stead to the motivations of the actors 184 directing attention intinction Act seems to have little if anything ${ }^{184}$ Inially, at least, the ited dctivities on profit motivation. It is cas to say about a disWhile many, which are defined in terms in terms of prohibponent, ${ }^{185}$ y of those prohibited activities include an in effects. vant, ${ }^{1}$ s. which might make an inquiry inde an intent coman inference itself only would be material into motivation releGiven that businest a party intended to obstruct it supported tive," any such infes are commonly animated by competition.

, any such inference would be exceeding the "profit mo-

To incorporate a process-based

vans is inconsistent with both of the welfare to explain antitrust doctrine goals most commonly adpays more the protection of small busine promotion of social market is than the competitive price regardi ${ }^{187}$ The consumer tioned is distorted by a private, profiteeringardless of whether the small dealers presumptively "public-spirited") sive dealing will suffer equally from predatory cartel. Similarly, posed by arrangements imposed by the state pricing or excluposed by private parties.

Professor Elhauge

legislative history of the Sherman support for his view in the vincing. Professor Elhauge cites Act, but the support is unconthrough the charging of high prices the flecing of consumers which the Shermang of high prices as the "one of consumers cast in terms of the was directed. ${ }^{188}$ This, of central evil" at consistent with the economic effects of a given active, is a goal laws is the adh the interpretation that the given activity, and is fleeced consumerement of consumer welfare state either or imposed the fleecing. One could argue hat decisions produced Profer Wilcy also would use what could beciled a process value That decisions produced through free riding are suspect be called a process value-
antitrust laws.

185. See, e.g., 15 U.S.C. $\$ 2$ (1988).
186. See Times-Picayune Pub.

completed offense of monopolization United States, 345 U. 594 , do the act, ... a specific intent to destroy comection 2 de.S. 594, 626 (1953) ("While the guilt for the mere attempt now to destroy competition or build only a general intent to ment as applied to private conduct would indeed, were it otherwise, the is essential to own profit.

188. Elhauge, Antitrust Process, supra note 99 , at 698 . that a consumer fleeced with the state's complicity can fight back through the electoral process, but that begs the question. ${ }^{189}$ That a consumer may protect herself from exploitation by voting does not mean the antitrust laws were not meant for her protection as well. ${ }^{190}$

Professor Elhauge also notes that no objections were raised to state-imposed restraints in the legislative history of the Sherman Act. ${ }^{191}$ This is not very surprising. As has been pointed out before, ${ }^{192}$ Congress had no reason to think the law it was passing could even apply wholly within a state. The only conflict Congress would have worried about would have been with other federal laws, which cannot be resolved by reference to the Supremacy Clause or federalism. ${ }^{193}$ Moreover, when the Sher-

189. It also is unlikely to be effective. As discussed in brief above and more fully below, if the state and a private actor act strategically, they can spread the cost of a given measure so widely among consumers that each individual consumer will be rationally ignorant of the source of the added expense, and thus effectively powerless to do anything about it. See supra notes 85-86 and accompanying text; see infra notes 211-218 and accompanying

190. See City of Lafayette v. Louisiana Power \& Light Co., 435 U.S. 389 (1978) ("Mulcted consumers and unfairly displaced competitors may always seek redress through the political process. In enacting the Sherman Act, however, Congress mandated competition as the polestar by which all must be guided in ordering their business affairs.").

191. Elhauge, Antitrust Process, supra note 99, at 698.

192. See, e.g. Easterbrook, supra note 99 , at $40-41$.

193. Professor Elhauge acknowledges this argument, but does not find it compelling. Elhauge, Antitrust Process, supra note 99 at $701-02 \mathrm{n} .169$. He makes two main points. The first is that the Sherman Act Congress was familiar with the phenomenon of state authorization of things such as holding companies and trusts that the Sherman Act was designed to abolish. The problem with this argument is that, to the extent Congress's intent is Co. v. United States, 193 U.S. 197 (1904), the Court found the Act to apply to the very trusts and holding companies the state had authorized. This hardly to apply to the very that Congress intended to defer to anticompetitive state legistation. supports an inference (rejecting argument hat state's antcompetitive state legislation. See, e.g., id. at 345-46 merger immunized company from antitrust approval of holding company created by merger immunized company from antitrust scrutiny). Far from suggesting that the legisladecisions suggest of or unwilling to address the problem of state restraints of trade, these decisions suggest that the Congress that passed the Sherman Act was perfectly willing to apply that law to state-sanctioned monopolies. Professor Elhauge's citation of legislative history indicating that such monopolies were not Congress' major concern does not establish a congressional intent to immunize them altogether. Such an extrapolation is particularly suspect given the dramatic expansion in state regulation of the economy between 890 and the present.

Professor Elhauge's second point is that even if Congress's intent was constrained by its view of its jurisdiction, we may still apply the principles Congress intended to embody in the Sherman Act to the expanded jurisdiction of the Act today. This is a fair point, even in view of the quasi-constitutional nature of textual interpretation of the antitrust laws. See Harlan M. Blake, Conglomerate Mengers and the Antitrust Law, 73 Colum. L. Rev. 555, 577 \& n.83 (1973). But the argument does not establish that Congress intended to except state regulation from the Sherman Act because it trusted states more than private actors. If we take the principle embodied in the Sherman Act to be the promotion of consumer welfare, we still have to resolve the conflict Professor Elhauge hopes to avoid in his theory. 
cerned about state regulation of the much reason to be conbusiness "clothed regulation was more or less as there is today. teeth in "clothed with a public interest.194 strictly limited to stated as 1890 and for some time thereafter This limitation had adoption of 1923 that "[i]t has never been. Chief Justice Taft the baker the Constitution, that the business supposed, since the the miner, the tailor, the wood chopper, the of the butcher, or of his product clothed with such a public interest operator or It is hard to or his wages could be fixed by sterest that the price category as imagine why raisin growers by state regulation." 195

ence between saying that the one. There is a fair bit of differrein in with the Shering that the monopolists Congress gress therefore Sherman Act were private and sains wanted to ing. Professor was not concerned about and saying that Conbeneficiaries Elhauge agrees that consumers werctioned fleecambiguries of the Sherman Act. Even concedine the intended preting the one should at least demand a geding that all else is with the sthe antitrust laws to allow the consod reason for interfuse the late's complicity-a better reason thers to be fleeced than subgislative history with coherence than seeking to in-

The legislative historyic, lines.

tinction bislative history aside, Professor Elhauge's prop tions fails in its profit-motivated actions and the state action casential task-to provide a better expterested acsor Elhauge eschews. troduces under a originally rejected a different label the public-privaten merely reinimmunity ultimate Arguments about state action atsinction he and democratic converge on substantive ideas petitioning ception. The ulic values. Professor Elhauge's areas of democracy cention. The ultimate justification for Profesument is no exFrom a public choice persecie Professor Elhauge's posithe constituents of senators in 1890 were state Elhauge would be betier put arguing that that senators would constrain the authority of legislators, not consumers. It is ung that goal of consumer welf now, however, whose interests constituents to regulate. Senators 194. Munn $v$. Illinois, than are those of state legistators perhaps more in tune with the 195. Charles Wolf Pack U.S. 113, 132 (1877) legislators. As late as 1929, Justice Sucking Co. v. Court of Indust.

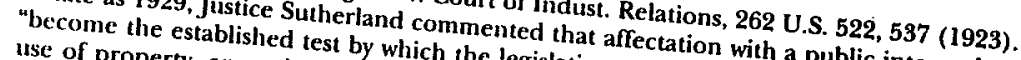
use of property, or services, must be measured." Williams v. Standices of commodities,
235,239 (1929).

tion is cast in precisely those terms, and parallels the assumptions regarding public and private activity that the Court adopted in Allied Tube. ${ }^{196}$ Because he draws heavily on the Allied Tube reasoning, the balance of Professor Elhauge's argument may be examined in light of the Court's assumptions.

Three assumptions are of interest here: (1) that there is a public interest separate and distinct from the aggregate private interest of producers and consumers; (2) that the private actors' interests diverge from the public interest; and (3) that the public actors' interests do not. ${ }^{197}$ These assumptions are reflected in Professor Elhauge's premises that, unlike financially interested parties, "financially disinterested and politically accountable" actors "lack the structural financial incentives to restrain trade in ways that harm the public interest. ${ }^{n 198}$ In his view, these premises constitute substantive antitrust doctrine: "Antitrust law embraces the principle that financially interested parties cannot be trusted to restrain trade in ways that further the public interest. ${ }^{\text {199 }}$

The Court's first assumption, that there is a normative public interest that is different from private interests, may or may not be true, which is to say it is of questionable value as an assumption. It is clearly untrue much if not most of the time, which makes it of even more questionable value. In the first place, the antitrust laws themselves embody a conception of what is in the public interest. Those laws are designed to promote consumer welfare and, therefore, efficiency. By hypothesis, the public interest the Court refers to in Allied Tube must be different, because that public interest can be achieved by a state adopting inefficient measures. But neither the Court nor Professor Elhauge ever provides a means for ascertaining what this public interest is, and thus there is no way to know who is and who is not acting to further it.

Professor Elhauge correctly contends that private parties often stifle competition and reduce output for their own benefit. But to conclude that private interests therefore diverge from the public interest ignores competition in the market as a method of ag-

196. See Elhauge, Antitrust Process, supra note 99, at 688

197. See supra note 86 and accompanying text; Allied Tube, 486 U.S. at 501 (quoting Hallie v. Eau Claire, 471 U.S. 34, 45 (1985)) ("We may presume, absent a showing to the contrary, that [a government] acts in the public interest. A private party, on the other hand, may be presumed to be acting primarily on his or its own behalf.").

198. Elhauge, Antitrust Process, supra note 99, at 703.

199. Id. at 696 . 
gregating preferences and allocating resources. ${ }^{200}$ As this first
assumption turns on the retion and the public good, this is a subship between private interests When one steps back from a substantial, perhaps fatal, omission. the market as a whole, one sees numerous one firm to look at ing to get ahead. To borrow a description greedy firms compettends only his own security; and by direction, each producer "ina manner as its produce may be of directing that industry in such his own gain, and he is in this, as in manyt value, he intends only invisible hand to promote an as in many other cases, led by an tion."201 It takes the fallacy of compos no part of his intenence against private action from composition to derive a preferprivate actor. Under the nom the greed of an individual antitrust laws, individual private conception of the goals of the precisely the state of affairs the greed is desirable; in fact it is maintain. ${ }^{202}$ antitrust laws are designed to

"professor Elhauge offers an alternative to the elusive search for argues that his process theory is agregate private interests. He gregate economic efficiency is consistent with the idea that agbecause interested (profit-motivated) the "public interest"203 proved upon by antitrust review, but decisionmaking can be immotivated) decisionmaking cannot 204 disinterested (non-profit ment, state actors enjoyim cannot. ${ }^{204}$ According to this arguto the public sector will not promotecause applying antitrust law lively than leaving government alone competition any more effecfor the states to pursue anticompetitive recause it is desirable petitive regulatory programs. ${ }^{205}$

any conceivable public process for measuring holds a comparative advantage over almost with state ordering of economic choices are legion. It is virtually
less possible-inces. The problems about supply and demind interconnected world economy to collect enoughable-much 201. I Amus demand to set prices and production levels from a cugh information TIONS 477 (U. Clii. Press INQUIRY INTO THE NATURE aND CaUs from a central source. 202. Indeed. Chi. Press ed. 1976) (1776). 202. Indeed, we may safely say that efricie

while inefficient firms are not. Within the paradigm of conting in the public interest, assumption but a truism. The public interest is defoned consumer welfare, this is not an Even if one does the lack of it) is the force that drives by demand, and demand (or Even if one does not work from a consumer wele drives inefficient firms out of business text still holds true. Society derives no benefit from model, however, the discussion in the tion misallocating resources that could be more an inefficient firm, which is by define tect the small dealers and worthy persons, more useful elsewhere. If one wanted te profrom consumers to that class, leaving the resource should favor a straight transfer payment 203. Elhauge, Antitrust Process, supra noteurces free to seek their highest and best use. 204. Id. at 707-08. 205. See id.

So long as we maintain the assumption, embodied by the antitrust laws, that competition is in the public interest, this theoretical construct is demonstrably untrue. Government regularly acts to place barriers in the way of private firms attempting to compete on the merits, and sometimes stifles competition entirely. We have discussed this anticompetitive government action in some detail above. ${ }^{206}$ Antitrust can act toward governments in the same way it acts in the private context-as a facilitator for the market, enabling aggregate social welfare to be efficiently determined by removing the barriers to robust, unfettered competition. Government barriers are just as inimical to competition as private ones, and their removal is just as likely to promote competition and therefore aggregate economic efficiency.

Of course, Professor Elhauge's point could be a much more limited one-that the same sorts of incentives that cause "disinterested" legislators and executives to restrain competition will also hobble the courts. Professor Elhauge has advanced a similar argument in the context of constitutional interpretation. ${ }^{207}$ Professor Elhauge contends that "identification of defects in the political process does not demonstrate that substituting a judicial process of decisionmaking would improve the situation." ${ }^{208}$ His point is that judges might "err in assessing, weighing or maximizing" competing social interests. ${ }^{209}$

This argument has some force in the constitutional context, where courts sometimes lack what Professor Elhauge has termed normative baselines by which to judge a given law. ${ }^{210}$ Professor Elhauge is rightly concerned by the prospect of judges weighing competing social interests, which is commonly considered a legislative task, especially in the absence of any statutory benchmarks. But unlike constitutional interpretation, here the antitrust laws provide the necessary benchmark for decision: economic efficiency. The question of defining the public interest thus reduces, at least so far as Professor Elhauge's theory is concerned, to whether judges applying the antitrust statutes in an effort to promote efficiency are more likely to reach efficient outcomes than legislators who are making no such effort. Thus posed, the ques-

206. See supra section II.A.

207. Einer R. Elhauge, Does Interest Group Theory Justify More Intrusive Judicial Review? 101 YALE L. J. 31 (1991) [herineafter Elhauge, Interest Group Theory]

208. Elhauge, Antitrust Process, supra note 99, at 725 .

209. Id.

210. Elhauge, Interest Group Theory, supra note 207, at 49. 
tion answers itself in favor of application of the antitrust laws. If it
did not, if courts perform ciples that competition was better off at enforcing antitrust prinacting deliberately to restrain trade in the hands of legislators have to question the point of applying one would seriously whether to public or private actors.

The Court's second assute actors.

actors diverge from the "public interest, is similarty of private sive. Both the Court and Professor Elhaust" is similarly unpersuasumption in terms of a presumer Elhauge have framed this aswhich public and private actors are aference in the degree to and, one may assume, to the "public accountable to the public flawed because private actors "public good." This assumption is the "public interest" than government more likely to promote tors are accountable to consumers officials since private acthan legislators are to voters, at least a much more direct way issues. ${ }^{211} \mathrm{~A}$ private actor in a competitivelatively uncontentious prices finds he has no customers and ine market who raises his will have no business. Relaxing the in relatively short order, market may lengthen the firm the assumption of a competitive

The diference in accountabilityise, but will not prevent it. ${ }^{212}$ mental actors may be explained in termeen private and governand "rational ignorance." 13 Consumers of information costs get the most for their money, and they will all markets want to mation necessary to do so.214 This mey will try to gather the inforto incur information costs up to a means they are already willing of buying a good or service. The ration level as part of the cost thus be less severe with consume rational ignorance problem will

coters because con-

211. This is not to say that relatively contentious issues necessarily pose a big
Witness the phenomenon of on one issue determines the individual issue voter-one for whom a candidate's problem. could wreak havoc on the Court's presumption A large number of truly single-issue position antagonize her constituents on all but onption, because the legislator would be voters dearly for their devotion to on all but one issue. Single-issue voters run would be free to siveness and (at least potentially) in direct in abstract terms of their legislator's paying 212. See Wilt lam BAUMOL. ET AI irect monetary terms as well.

Structure (1982).
213. Rational ignorance is a term al., Contestable Markets and THE Theory of INDUSTRY

tiin amount to obtain information. that indicates that consumers will spend only a

than the knowledge will save them. If obtaining that information costs consumly a cerinformation. See RALPH Tave them, consumers will rationally choose consumers more Jonathan R. Macey, Public BhrNS \& GERALD W. STONE, ECONOMics 433 (4th acquire the CORNEI. L. ReV. 43, 47 Choice: The Theory of the Firm and the Theor 433 (4th ed. 1989); 214. By and large, 47 n.17 (1988).

service.
provide the most of a product or service relative to the cost of the product or

sumers are already motivated by the necessity or desire to make certain purchases to incur the costs necessary to hold sellers accountable. The Court at one time recognized this difference in the commercial speech context, noting that consumers may well be more interested in prices than in current events. ${ }^{215}$ Just as it is harder to hide a transfer payment funded through taxes than one funded through some obscure regulation, it is harder for a producer, who does not have the luxury of passing an obscure regulation himself, to raise prices. For these reasons, private actors who displease consumers are more likely to be held accountable than are legislators.

The consequences of accountability for private actors are also likely to be more severe than is the case with public actors because the costs of imposing accountability will frequently be much lower for private actors. Assuming the consumer is willing to bear the cost of informing herself of the quality and price of other brands, which she is presumably doing anyway by virtue of being in the market, she can "vote with her wallet" and switch brands. At least for inexpensive and frequently purchased items this will require little if any extra effort. In other words, holding producers accountable may require a consumer to do little or nothing more than they would do anyway in an effort to be an efficient consumer. ${ }^{216}$

By contrast, a legislator will normally have some form of tenure, necessitating either the extraordinary measure of a recall vote or delaying accountability until the next election. Even then, the consumer's search for wealth maximization is likely to make him rationally ignorant of much in the public sector, largely because of collective action problems. In other words, while a consumer reaps an immediate benefit-lower prices-from. switching brands, there is no corresponding benefit to voting

\footnotetext{
215. Virginia State Board of Pharmacy v. Virginia Citizen's Consumers Council, 425 U.S. 748, 765 (1976) (striking down state legislation that prohibited advertising of drug prices by pharmacies, in part because consumers need this information in order to make rational purchasing decisions).

216. This of course will not hold true in all circumstances. As Eastman Kodak Co. v. Image Technical Services, Inc., 112 S. Ct. 2072, 2085-87 (1992), illustrates, some consumers may be stuck with long-term obligations and be unable to do anything about a change in the cost of their product relative to the market. How frequently this is a problem is an empirical question we cannot answer here. The odds are fairly good that this does not affect the relative difficulty of changing brands in the market and ousting a wayward legislator, because problems such as the tenure of incumbency (or perhaps civil service protection in the case of a wayward bureaucrat) are pervasive, if not universal, in the public sector.
} 
will even one legislator (much less a majer of voters act together Thus, it will often be rational fors a majority party) be ousted. herself about prices in the for a consumer-voter to educate records in Congress.

This is not to deny th

sometimes monopolize a market or or in groups, greedy firms cessful cartel. The question is what cooperate and form a succisely in this case, what assumption to do about it or, more prefavor of or against congruity of public and we choose-one in value of an assumption depends public and private interests. The real world, ${ }^{217}$ and our criterion for how accurately it reflects the the assumption that most accurately decion should be to prefer question comes down to whether, as an erribes reality. Thus the of private actions is in harmony with the pirical matter, the net often than the unconstrained with the public interest more governments. ${ }^{218}$ unconstrained actions of state and local

Answering

sions will of course vary with the substy difficult and the concluand values the analyst incorporates instantive criteria, definitions good. ${ }^{219}$ For our present purposes, and concept of the public sumer welfare perspective, it is enough working from the conthe Court perceives with private action to say that the problems less one takes into account market solure greatly overstated unGreedy cartel members cheat, precisely be to those problems. and self-interest, thus imperiling thecisely because of their greed toward a competitive level, ${ }^{220}$ and other firtel and driving the price 217. In cost-benctions will be attracted, by savings (in information costs) me might say assumptions are valuable to the extent curred ihrough oversimplification. 218. Such an evaluation is ation.

Ellhatige is correct that pun is not the end of the matter, of course Even good, he still must determic action is superior to private action ine. Even if Professor velicle to that end, because a whether legislative or judicial action is thering the public nity while a preference for a preference for legislative action justion is the appropriate rect that private a circumstances judiciegation of preferences is superior we still. Similarly, if we are corprivate action. 210. If for

the critcrion example, one considers the degree to be the worst of julging whether a given action or which wealth is equally distributed as paradigm should bossible worlds because it is (and at least with or bad, the market will assumption should be) indifferent to distributional at least within the consumer welfare comes are desiould be drawn folds quickly into the concerns. Thus the question of what quickly into the analyst's substantive view of what what

cartel members have to expand producte 113, at 141-45 (focusing on the strong incentives virtue of their greed, to the cartelized industry. Professor Elhauge's theory lacks force to the extent one views the market (which is to say the aggregated private preferences of producers and consumers) as more closely tracking the "public interest" than does governmental intervention. ${ }^{221}$

Moreover, even if one grants that private actors frequently take steps inimical to the public interest, all that follows is that the antitrust laws should be applied to sanction such private actors. And if one assumes that private actors undercut the public interest when they contrive certain economic effects, by parity of reasoning one could argue that public actors should be subject to a similar assumption for producing similar effects. Far from justifying state action immunity, then, this assumed market breakdown may in fact provide a reason for applying the antitrust laws.

The Court's third assumption, that the interests of public officials do not diverge from the "public interest" (or at least diverge less than the interests of private actors) because public officials do not act for a profit, is equally problematic, though it has received surprisingly little attention in the state action literature. ${ }^{222}$ If we take the actions of producers in seeking anticompetitive regulation as the "demand" for such regulation, we may look at legislators, regulators and other public actors as the "supply." If the demand side of anticompetitive regulation is characterized by collective action logic, what characterizes the supply side? The answer of public choice theory is that many of the same characteristics apply, including the notion that public actors have an essentially financial stake in the actions they take.

In 1784, John Marshall, then twenty-nine and a member of Virginia's General Assembly, complained in a letter to James Monroe that "[n]ot a bill of public importance, in which an individual was not particularly interested, has passed." ${ }^{223}$ Things

market share in the short run but endangering the cartel in the long run); POSNER, AN Economic Perspective, supra note 2, at 52-54 (same).

221. A similar line of argument may be found in Professor Epstein's critique of the civic republican theories of Professors Michelman and Sunstein. Richard A. Epstein, Modern Republicanism-Or The Flight From Substance, 97 YALE L. J. 1633 (1988).

222. It should be noted at the outset that Professor Elhauge is admirably frank in his discussion of the shortcomings of public officials' decisions. Eihauge, Antitrust Process supra note 99, at 717-18. His point is not that such decisions are perfect, only that they are taken in an environment that, objectively speaking, is relatively more conducive to decisions in the public interest than are private decisions-they offer a comparative advantage both to private actors and judges. As discussed below, Professor Elhauge's theory overstates the comparative benefits of public decisionmaking even with these caveats.

223. 1 Al.bert J. Beveridee, The Life of John Marshall 228 (1919). 
have not changed much. Recall that in Omni the council memshore up its monopoly position alleged retitive regulations to advertising come election tion allegedly received free billboard tive, the free billboard space was a share an economic perspecprofits given to the legislators in share of Columbia's monopoly Omni's account of the case it is imange for their votes. On grounds of financial interest it impossible to distinguish on from the public actions of the private actions of Columbia ence of an individual finat of council members. ${ }^{225}$ If the presthat the interests of a private incentive compels the conclusion the same conclusion should apply diverge from the public good, an incentive. the City provides further financial collusion between Omni and view of these cases. To call the mon to reject Professor Elhauge's interested" would be to deprive the legislators in Omni "disNonetheless, that is precisely the word of any meaning at all. cludes. ${ }^{2215}$ In our view, that Profest Professor Elhauge concouncil's action in Omni as "disinter Elhauge defends the city light his incorporation of what he criticiz" only serves to highthe public-private distinction.

Professor Ehauge's assumption that government officials act
in the public interest must also contend in the public interest must also contend with the teachings of
public choice theory. Public chice presumption of rational, purposive behavior simply applies the regulators). ${ }^{227}$ Stated this way, the behavior to legislators (and controversial. The dispute is over proposition is relatively unattempt to maximize. As Professor traditional liberal account lefessor Elhauge points out, on the persons affected by their actions, weighing the interests of all in a deliberate fashion, and choosing the the varying interests

224. See supra text accompanying note 89

225. It is likely that liec billing note 89.

portion of Omni's monopoly profits. It and campaign contributions took only a small between public and private decisionmaking based impossible to construct a difference case, however, and Professor Ellaume's theory on the amounts at stake in any given 226. See Elhauge, Petitioning Immunity supra notes no such attempt.

227. See Damiel A Fato 124445.

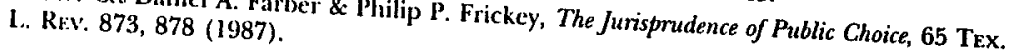

sider best for the public as a whole-that is in the "public interest. ${ }^{\text {2228 }}$

The public choice account rejects such a model as naive. ${ }^{229}$ Public choice theory presumes that once in office, legislators want to stay there. They maximize their own chances for reelection, or perhaps advancement to higher office. ${ }^{230}$ At first this might not seem to pose any problem. If a legislator wants reelection or advancement, on a public choice account she presumably would act so as to benefit the greatest number of constituents, thus gaining the greatest number of votes. Unfortunately, however, the reelection or advancement-maximizing legislator is not as interested in acting for the benefit of most of her constituents as she is in doing so as far as they know. In other words, the problem is rational ignorance on the part of the electorate. A selfinterested legislator will write laws whose burdens will be sufficiently diffuse that her constituents will not have enough at stake to make it worth their while to undertake the investigation necessary to discover that she is fleecing them. At the same time, the benefits of the law will be sufficiently concentrated to be both identifiable and significant to the beneficiaries. This state of affairs is optimal for the legislator. The beneficiaries of the regulations are happy and contribute funds or free billboard space to the legislator's next race, thus maximizing her chances of reelection. At the same time, there is little or no cost in terms of constituent dissatisfaction. This analysis implies that the legislator's best move is to transfer as much of her constituents' wealth as possible to groups that will give her a return on her efforts without raising the constituents' suspicion and thus incurring a cost. $^{231}$

228. Elhauge, Antitrust Process, supra note 99, at 703. Of late this model has been adopted by what Professor Sunstein has termed a "revival" of civic republican theory. See Cass Sunstein, Beyond the Republican Revival, 97 YALE L. J. 1539 (1988); Cass Sunstein, Interest Groups In American Public Law, 38 STAN. L. Rev. 29 (1985)

229. See generally Farber \& Frickey, supra note 227, at 879 .

230. Omni provides a good example of the more general point of public choice theory because of the identity of the anticompetitive regulation and the payoff to the public official - for the regulatory preservation of a billboard monopoly the regulators were paid in billboard space. But the same dynamic is at work throughout the legislative process. It may take the form of outright corruption-bribery or the notorious case of the "Keating Five" Senators. But it may also be more subtle. Consider the concept of "logrolling," a practice where legislators vote for measures valuable to one of their number in the expectation of a reciprocal vote in the future.

231. This is why legislatures are likely to prefer regulation to taxation (which is relatively more efficient) for transferring wealth from the general public to some special interest. As the previous discussion of private accountability demonstrated, it costs less to find out that one is being taxed than to find out that one is paying too much for raisins 
public choice arguments to say, as her Elhauge in responding to into account the differing incentives does, that his theory takes to pursue that good. 232 incentives of public and private actors ory, but it begs one of most foes not refute public choice thepresents. In public choice theory the questions the theory ontological public good-the first the notion of some sort of is incoherent. To borrow the first assumption discussed abovestein, eloquent critic of public description of an Professor Sunception treats the ... notion of theory, " $t]$ he pluralist conincoherent, potentially totalitarian, or both "233 common good as the term "public good" in a public or both."233 If one must use to "uninhibited bargaining public choice analysis, it would refer that numbers and intensities of political outcomes. The common preferences can be reflected in tion of individual preferences."234 good amounts to an aggrega-

\section{To the extent Profersor Elhauge de}

thinking of, it is by reference to defines the public good he is through the actions of politically accountablion of that good interested actors. Of course, the two stronle and financially dispublic choice theory are that public strongest attacks made by financial interest in the that public officials frequently have a not be accountable for the wealth they make and that they need the argument of public choice theory is transfer. In other words, ter the "objective incentives" of public and an empirical matlargely the same. Professor Elhauge's and private actors are cause it provides no reasons to reject argument lacks force beof legislative action.

In sum, Professor

tially casts it, as a rejection of theory is best read not, as he inibut as an effort to set forth of the public-private distinction itself, tinction. But, as noted above, there is criteria to make the disnor analytical basis to presume that legislators ("finand empirical ested" or not) will act in some definabislators ("financially inter-

inte pri-

the transfer of their wealth by tax and constituents are therefore more likely to learn of

Posner, Economic Anatisis by tax and object to it at the next election. See Richarn of

232. Elhauge, Antitrust Process, supra (3d ed. 1986)

233. Cass R. Sunstein, Process, supra note 99, at 719.

(1985) [hereinafter/nterest Groups]. Professor Sunstein's ric Law, 38 STAN. L. REv. 29, 32 stein, Beyond uses pluralism to refer to "interest-group reference to pluralism should no 234. Sunstein, Interest Groups, supra note 233 at $32-33$, 1542 (1988). vate actors will not. Nor does Professor Elhauge offer such support. He simply attributes the basis for his assumptions an unstated congressional intention lodged in the Sherman Act. This attribution does not withstand scrutiny. Consequently, Professor Elhauge's theory does not meaningfully improve on the publicprivate distinction. In part, this is because Professor Elhauge's goal of explaining the Court's state action cases requires him to define a disinterested, accountable actor as anyone who is either elected or was appointed by someone who was elected, or was appointed by someone who was appointed by someone who was herself elected. ${ }^{235}$ That comprises most of the government, if not all of it, thus undermining Professor Elhauge's efforts to escape the public-private distinction he criticizes.

As this section argues below, the state action cases can only be justified and explained along the lines that Professor Elhauge criticizes but implicitly adopts. At least if one is to deem a given state of affairs as "in the public interest" when it comes from the legislature and "against the public interest" when it comes from the market, one must explain why the points of distinction between the legislature and the market are significant, and do so in terms of the public interest which must itself be defined in terms relevant to the debate. In other words, a process-based analysis adds a step to the definition of the public good, but it does not obviate the need for an underlying substantive norm or norms at which the process is directed.

\section{Clear Statements, Active Supervision, And Principles of Governance: How Panama Refining Co. v. Ryan and Deterrence Theory Became Part of The Antitrust State Action Doctrine}

This section discusses the Court's treatment of the intersection between antitrust and the public interest. It attempts to answer a perplexing question: how can we justify, on grounds of federalism, restrictions on a state's ability to adopt regulations that may give private actors control over output? In answering this question, we focus on the same principles that the Court has said

235. Elhauge, Antitrust Process, supra note 99, at $671 \mathrm{n}$. 10. According to Professor Elhauge, an actor is "politically accountable" if "his or her authority can be traced to an election, appointment by elected officials, or through some chain of appointment starting with elected officials. Ongoing political accountability is not required; it is sufficient that the political process can influence the initial selection of personnel to exclude those with
unacceptable policy preferences." 
guide it-theories of governance and basic principles of democfine the actors conceives of federalism as serving in part to dethose actors may be subject to a given state of affairs, so that this end, the Court has shect to public approval or rejection. To trine to facilitate the dialogue the state action immunity docgoverned, encouraginglogue between the governors and the draft, and to watch over anticompetiti about the policies they ment. ${ }^{236}$ The Court also anticompetitive programs they impleliability will not impede the dialoght to ensure that the threat of will not be subject to liability forue by holding that legislators corallary benefit that their intent in the votes they cast, with the scrutinized by the courts.

The Court's rule, as stated simple:

A state law or regulatory scheme cannot be the basis for anti-
trust immunity unless, first, trust immunity unless, first, the State has articulated a clea and second, the policy to allow the anticompetitive conduct, petitive conduct underaken active supervision of anticom-

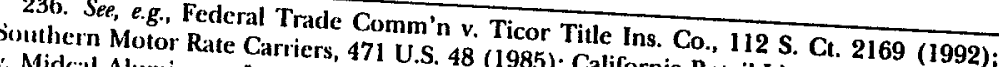
v. Midcal Aluminumn Inc. 445 U.S. 47 (1985); California Retail Liquor Dealers (1992) 237. Federal Trade Co., 445 U.S. 97 (1980).

California Retail Liquor Ass'n v. Midcal Aluminum, Co., 112 S. Ct. 2169, 2175 (1992), citing state action inmunity was unavailable under title inc. 445 U.S. 97 (1980) (holding that Montima). The rulc contains a substantial qualification Begute regulion in Wisconsin and tion is rooted in the federalism principles cited in Pan. Because the immunity in quesimmunity does not apply to local governments in Parker, the Court has concluded that crence of the States that created them." City of Lafayen "do not receive all the federal defCo., 435 U.S. 389, 412-413 (1978) (holding that all govette v. Louisiana Power and Light statc status). Tho the votes of only four justices Court in Community fustices, the rule and language were adopted by a which enjoyed (1982) (finding insufficientunications Co., Inc. v. City of Boulder, 455 majority of the ity's temporary insufficient state authorization under state "houlder, 455 U.S. 40, 50-51 hats also been prohibition on expansion of existing cable television fran for municipal(1985) (staten applied in Town of Hallie $v$. City of television franchise). The rule (1985) (state granted municipality sufficient authority of Eau Claire, 471 U.S. 34, 38-39 sewage treatment policy), and, of course, City of Colymb to enforce allegedly anticompetitive thority over C. 1344, 1349-51 (1990)(holding a columbia v. Omni Outdoor Advertising views over billboards sufficient to provide immunity vriucipe cases as creating a three-tiered structure in principal officers are genuine state action, actions of wich acts of the state legislature and atthorization but not active supervision, actions of local governments require clear state involving private parties require both a clear state localities may provide, and actions Antitrust Process, supra note 99, at 672-75. Profestement and active supervision. Elhauge, lases, and receives further support from both Professor Elhauge's article was published both Omni and Ticor, which were issued after
Understanding how we got that rule, whether it makes sense, and, if so, why, are all much harder questions.

In the first place, why is it a matter of antitrust concern whether an anticompetitive state policy is clearly stated or closely supervised? The short answer is that it is not, really. According to the Court, Parker and its progeny are "grounded in principles of federalism."238 "Federalism," the Court continues, "serves to assign political responsibility, not obscure it." ${ }^{\text {239 }}$ Thus, "[s] tates must accept political responsibility for the actions they intend to undertake."240 These are general principles of governance; they would apply just as well to any other area of law as to antitrust. ${ }^{241}$ The clear statement and active supervision requirements demonstrate that the Court's willingness to grant antitrust immunity to anticompetitive state actions turns on such general principles, and provides further evidence that the rule of decision in these cases is not derived from the antitrust laws.

The clear statement branch of the Court's rule has an obvious relationship to the Court's substantive concern that states accept responsibility for their anticompetitive schemes. Voters cannot decide whether they approve of the state's actions unless they know what the state is doing. This simple principle is fundamental to democratic government, for "popular choice will mean relatively little if we don't know what our representatives are up to." ${ }^{242}$ A state is more likely to admit what it is doing if the failure to do so would render its program subject to antitrust scrutiny. The clear statement requirement is thus designed to establish what Professor Ely termed a "visible legislative process." ${ }^{243}$ The more visible the legislators' actions are to the public, the easier it will be for the public to hold the legislators accountable for their actions. In economic terms, the Court is attempting to diminish the probability that consumers will be ra-

238. Ticor, 112 S. Ct. at 2176

239. Id. at 2178.

240. $I d$.

241. Professors Elhauge and Wiley argue that the active supervision requirement amounts to a contradiction in the Court's reasoning because it encourages states to regulate the market more closely, thereby offending the principles that animate federal antitrust law. See, e.g., Elhauge, Antitrust Process, supra note 99, at 675-76; Wiley, Capture Theory, supra note 36, at 719-723. This argument is unpersuasive because it fails to account for the Court's view of what federalism means. As Ticor makes clear, the Court perceives a substantive component to federalism. Thus the Court can with perfect consistency deny antitrust immunity to a state regulation that does not satisfy those substantive minima. 242. John Hart Ely, Democracy and Distrust 125 (1980). 243. Id. at 125-31. 
tionally ignorant of anticompetitive state policies by decreasing the cost of discovering the existence of such policies and those
responsible for them.

The clear statement requirement has not been the subject of active supervision requiremly far less than its counterpart, the not a particularly high hurdle for fact which may suggest that it is have managed to pass laws from which to clear. States generally clear anticompetitive purpose which the Court could discern a minum, the case establishing As the Court put it in Midcal Alupolicy is forthrightly stated and two-part test, "[t]he legislative sale price maintenance."244 Midcal in its purpose to permit reon the clear statement rule- it impoints out a second limitation purposes are permissible

Like the clear statement so long as they are clearly articulated. requirement is designed to equirement, the active supervision held accountable for the ensure that state governments are sor Ely, this time in his discussion. To borrow again from Profescases, " $[t]$ here can be little point in the Court's nondelegation tion of the franchise and point in worrying about the distributhe important policy and other personal political rights unless fact, the famous nondeles are made by elected officials." ${ }^{245}$ In $R_{y a n^{246}}$ and $A . L A$. Schectegation cases, Panama Refining Co. v. striking resemblance to Parker All Corp. v. United States, ${ }^{247}$ bear a the early New Deal mold ${ }^{248}$. All three concerned statutes in Act (NIRA), ${ }^{249}$ at issue in Schecter, National Industrial Recovery for the Agricultural Pror Schecter, could have served as a model promulgate codes of "fair competition" , usually acting at the be-

244. California Retail Liquor Dealers Ass'n v. Midcal Aluminum, Inc., 445 U.S. 97, 10
(1980) (holding that Caaforn's 245. Ely, supra note 242, at 133. Professor system violated federal antitrust law). doctrine is cast in precisely the terms used by the Cofense of a vigorous nondelegation cratic, in the quite obvious sense that by refusing to the sort of accountability that is crucial to the intelligible, our legislators are escaping republic." Id. at 132 . 246. 293 U.S. 388

an unconstitutional delegation of coction 9 (c) of the National Industrial Recovery Act 247. 295 U.S. 495 (1935) (holding the Naional power).

tional as applied). 248. The Califo

ment Act, 50 Stat. 246, 7 U.S.C. $\$ 601$ (1937), 6 ,ed on the Agricultural Marketing AgreeCommerce Clause of the Agriculural (1937), which was itself the re-enactment under the under Congress' spending power, and hjustment Act of 1983. The AAA was enated States v. Butler, 297 U.S. 1 (1936). and the Court struck it down on that ground. United note 36 , at $719 \mathrm{n} .18$.

249. Act of June 16, 1933, c. 90, 48 Stat. 105, 106 (codified at 15 U.S.C 703 ) hest of trade associations. 250 "Fair competition" under NIRA meant no competition, and the codes commonly set wages, prices, and hours on terms proposed and enforced by the trade association. ${ }^{251}$ Justice Cardozo, who was not commonly opposed to New Deal measures, aptly termed this plan "delegation running riot. ${ }^{n 252}$ The description fits Parker quite well, and bolsters the intuition that if Parker had been decided at a less tumultuous time, California's raisin cartel would not have received such favorable judicial treatment.

The active supervision requirement serves to keep delegation from running riot in the state action cases, thus preserving accountability, even though the nondelegation doctrine is all but dead at the federal level. ${ }^{253}$ The Court's description of what it saw as the essential failing of the California statute in Midcal Aluminum is revealing:

The state simply authorizes price setting and enforces the prices established by private parties. The State neither establishes prices nor reviews the reasonableness of the price schedules. ... The national policy in favor of competition cannot be thwarted by casting such a gauzy cloak of state involvement over what is essentially a private price-fixing arrangement. ${ }^{254}$

The Court's holding is in the tradition of Parker's statement that a state cannot "give immunity to those who violate the Sherman Act by authorizing them to violate it, or by declaring that their action is lawful." 255

This is a limitation with some teeth, as the Court's most recent case on the issue illustrates. In Ticor, the Federal Trade Commission (FTC) brought suit against six of the nation's largest title insurers for violation of the Federal Trade Commission Act. ${ }^{256}$ The FTC alleged that the insurers had violated the Act's proscription of "unfair methods of competition" by fixing prices for title searches and examinations. ${ }^{257}$ In the states at issue, the insurers belonged to rating bureaus-" private entities organized by title insurance companies to establish uniform rates for their mem-

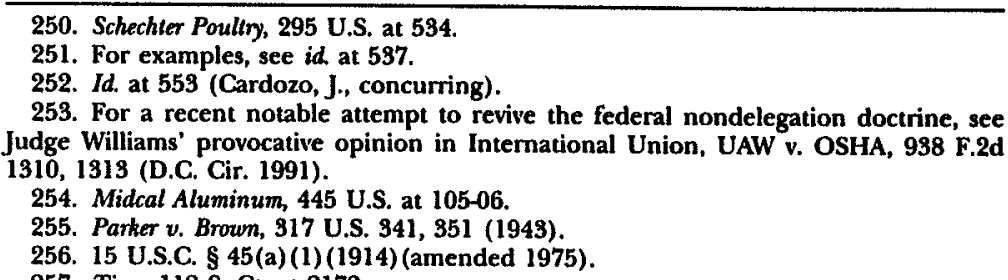


bers."258 The bureaus were licensed by the states and authorized within thirty days, the rates for approval. If the state did not act were bound to follow them 25 !

In light of their participation in this procedure, the insurers Court took the were immune from liability under Parker. ${ }^{260}$ The "active supervision" to decide whether the states had exercised ting collective rates. ${ }^{261}$ Finding for the FTC the insurers for setstate has not exercised active supervision, the Court held that a

sion unless

control so that the details of the independent judgment and tablished as a product of of the rates or prices have been esply an agreement among private parte intervention, not siminquiries, the antysis private parties. Much as in causation inting stantial role in determining the specifics of the economic
policy. ${ }^{262}$

This is a far stricter standard than the one the Court articulated in Panama Refining and Schechter Poultry. In neither of those cases would the Court have required that the government exercise required only that the recipients of that the government establish principles for the To delegated power to follow. ${ }^{263}$

To the analysis just described, the Court added some provocagument that on state action. Faced with the dissent's strong arscope of ret the Court was infringing on the states' legitimate sion requirement it imposed acity responded that the superviflexibility. ${ }^{265}$ This paradosed actually increased state regulatory prompted by a brief filed by thirtyment appears to have been cally, two of the states whose argued that a broad rule of policies were at issue. These states argued that a broad rule of immunity would not serve them well expected ways. ${ }^{266}$, sometimes their regulations develop in un-

\section{Ild. at 2174 .}

259. $I d$.

2(i0. $I d$.

262. Id. at 2177.

263. Thechter Poulliry, 295 U.S. at 530; Panama Refining, 293 U.S. at 421.

dissenting).

265. Id. at 2178
How might this happen? The thought seems to have been that states could pass well-intentioned regulatory programs that would get out of hand, becoming anticompetitive (or more anticompetitive than they were supposed to be) even though the state did not desire that result. Wisconsin and Montana-and thirty-two other states as well-argued that they had intended to create regulatory schemes in the public interest, not give a plum to the title insurance industry. Things did not work out that way, however, and the states had no interest in seeing the insurers, who had profited from this regulatory failure, immunized against any kind of liability. In this context, one may read the states as wanting to preserve antitrust liability as a possible punishment for regulated industries that "captured" their regulators, and in so doing diminish the probability that such capture would be attempted. The Court's discussion indicates that it sympathized with such an approach. In the Court's words, it did not want antitrust state action immunity to "compel a result that the States do not intend but for which they are held to account. ${ }^{267}$

Of course, this put the title insurers in a quandry, as Justice O'Connor's dissent observed. She argued that it was unfair to subject the title insurers to potential liability under the antitrust laws for submitting a joint rate filing when their liability would turn on how actively the state scrutinized the filing-activity that necessarily took place after the filing had been made. ${ }^{268}$ Justice O'Connor argued that "the regulated entity has no control over the regulator, and likely will have no idea as to the degree of scrutiny that its filings may receive, ${ }^{n 269}$ a statement that arguably reflects a more optimistic view of agency independence and rigor than is warranted by the facts. Her basic point is sound, however. The state action cases turn on whether the structure of a given anticompetitive program is sufficient to ensure that the state will be accountable for its actions. The beneficiaries of such regulations cannot control the accountability of public officials (at least after the adoption of the regulation). It thus makes no sense, and is more than a little unfair, to punish them because the government successfully avoided responsibility for its actions.

Justice Scalia concurred with the majority in Ticor, even though he said he is "skeptical about the Parker $v$. Brown exemption from

267. Id.

268. Ticor, 112 S. Ct. at 2183 (O'Connor and Thomas, JJ., dissenting)

269. Id. at 2184 . 
state-programmed private collusion in the first place."270 This statement by the author of Omni highlights the Court's tendency is show less deference to a state program the further removed it is from an actual enactment by a state legislature or its proxy. Pater and Ticor both involved the delegation of authority to private actors with minimal or nonexistent state supervision, while power.
Thed the direct exercise of traditional municipal zoning

The Court's distinction between direct and delegated straints of trade can be viewed as an attempt to give legised rebreathing space to carry out as an attempt to give legislators Omni contended the regulation their functions. The plaintiff in titrust scrutiny the regulation at issue was not exempt from antween Omni and the it was the product of a "conspiracy" bescope of an exce city government, thus falling within the Court used Oxception left open and undefined in Parker. ${ }^{271}$ The Court used Omni to limit this exception to cases in which the government acted as a market participant, and expressly disavowed reliance on the concept when the government was
legislating.

The Court's reason for limiting the co-conspirator exception was the fear that legislators might shy away from voting for desiravotes 273 Thes if they would be subject to antitrust liability for their tors and their constituents to it is often desirable for legislaa constiuent constituents to agree to pursue a given policy. That agreement might obtain a competitive advantage from such an tween legislators and change the Court's view that interplay becluded that if and constituents is desirable. ${ }^{274}$ The Court conscrutiny "wat if the city's regulations were subject to antitrust then the ability of the liability of city officials a possible consequence," would be comp of the states to regulate their domestic commerce point raised in the opinis ${ }^{275}$ This was perhaps the most important rained in the opinion, and it deserves careful scrutiny.

270. Id. at 2181 (Scalia, J., concurring).

271. Omni, 111 S. Ct. at 1351 . In Parker, the Court rather casually emphasized that it

Parker, 317 U.S. at 351-52, giving rise to the "co-carticipant in a private agreement. .

272. Omni, 111 S. Ct. at 1351 .

273. Id.

274. Id.

275. Id. at 1352 (emphasis added). This conclusion reinforced a concem the Cout had expressed when addressing the question whesion reinforced a concern the Court power to support the regulation. The Court whether the state had delegated sufficien of legislators under the antitrust aws mestic commerce" to describe intrast
The Court's reasoning on this point must be understood in terms of basic deterrence theory. All laws carrying sanctions are designed to deter some form of conduct. The antitrust laws seek to deter price fixing and similar activities by imposing treble damages, and in some cases prison terms. ${ }^{276}$ The deterrent effect of a given sanction depends on its severity discounted by the probability that it will be imposed. We can call this the expected detriment of a sanction, the discount factor applied to the expected value of unlawful conduct. Compared to other penalties for business conduct, the antitrust laws are fairly severe. Even for civil violations the penalties include treble damages and attorney's fees, which can be substantial. 277

Deterrence in the real world is not precise. Sanctions may be applied to conduct that was not in fact illegal, as when an innocent man is wrongly convicted. Especially in cases concerning activity near the hypothetical line of illegality, an actor might not know whether her conduct was lawful until after the fact. Even then, the conclusion might simply be a function of the particular jury drawn for that case. ${ }^{278}$ As a consequence, a risk-averse actor might steer clear of legal conduct that a jury might wrongly interpret as unlawful. That is what the Court feared in Omni. ${ }^{279}$ Faced with the prospect of treble damage liability, legislators might be inclined not to vote for valid regulatory programs they feared might later be attacked on antitrust grounds. The Court removed the overdeterrence problem altogether by rejecting

any interpretation of the Sherman Act that would allow plaintiffs to look behind the actions of state sovereigns to base their claims on 'perceived conspiracies to restrain trade'... . [A]ny action that qualifies as state action is 'ipso facto . . . exempt from the operation of the antitrust laws. 280

phrase more commonly used in reference to nations than states. The Court's language reinforced the point that states are considered limited sovereigns, and one area of their sovereignty (at least in theory) is intrastate commerce.

276. See, e.g., 15 U.S.C. $\$ 15$ (1982).

277. Id. Even if the damages actually awarded are low, the prospect of attorney's fees is significant. It is worth recalling that the defunct United States Football League won only a dollar (trebled to three) in its antitrust action against the National Football League. The USFL was still the prevailing party, however, and was awarded millions in fees. United States Football League v. National Football League, 704 F. Supp. 474 (S.D.N.Y. 1989).

278. This problem is greatly exacerbated in cases such as Ticor, because under the Court's current rule the legality of an actor's conduct does not depend on the antitrust laws or even on the actor-it depends on actions taken by the state.

279. Omni, $111 \mathrm{~S}$. Ct. at 1353

280. Id., quoting Hoover v. Ronwin, 466 U.S. 558, 568 (1984). 
The Omni plaintiff and amici had tried to persuade the Court
to adopt a variety of rules they conten to adopt a variety of rules they contended would allow antitrust
claims to proceed in proper tors. They argued that the Court without deterring the legislamunity when the regulation at issue was the a rule denying imor bad faith decisions" or when the was the product of "corrupt public interest." 281 The Court rejectedation was "not in the ever, holding that any Court rejected these suggestions, howa measure because inguiry into whether a legislator voted for interest or because she subjectively believed it was in the public would require the sort of quo for some improper inducement sought to avoid."282 immunity could be denied where rejected the suggestion that neitral (with respect to antitust it could be shown that some had been violated, such antitust and competitive concerns) law that violation of such a law dibery statute. The Court reasoned was not in the public interest not necessarily mean that a statute any event not rublic interest, and that such an approach was in

The concern over to any antitrust concerns. ${ }^{283}$

The concern over chilling legislative behavior may or may not than it received in $O m n i$ argument deserves greater attention eration: (1) the Court's three points in particular merit considliability could be made to turnent of the suggestion that antitrust as a bribery statute; (2) the Court's cotion of a neutral rule such into subjective legislative intent; and (3) the court' an inquiry immunizing all direct state actions from the Court's solution of

The Court rejected the actions from antitrust liability.

be imposed only when a neutral law that antitrust liability could been broken because "[s] uch unlaw such as a bribery statute had relationship to whether the governmental activi has no necessary interest." 284 The Court the governmental action is in the public ical influence as the test of edly vindicates (in a of legality of state regulation undoubtgovernment. But the statuter blunt way) principles of good that end." 285 The problem we are construing is not directed to acy alleged in Omni is significant this analysis is that the conspirinvolves the antitrust laws. The on two levels, only one of which

281. Id. at 1352 .

282. Ill.

283. li. at 1353 .

284. $l i$.

285. $l d$ at 1353 . ciples of governance that the Court has said provide the rules of decision in antitrust state action cases.

Simply put, the general principles of governance recognized by the Court as providing the rule of decision in every state action case since Parker do not permit states (or municipalities wielding state authority) to conspire with private actors. The Court in Ticor, for example, made it clear that it will not tolerate the delegation of state power to private actors because that impairs accountability, which is in turn crucial to the democratic process. ${ }^{286}$ As Professor Ely put it, the vote is not worth very much if the real power lies with unelected officials. ${ }^{287}$

With this premise in mind, let us alter the facts of Omni slightly. Instead of passing a law banning new construction of billboards, suppose the city enacted legislation establishing a commission to investigate the billboard situation and make a recommendation that, if not altered or disapproved by the city, would become law in thirty days. Suppose further that to keep information costs down, the law provided that the board would comprise representatives from firms that already owned billboards in the city. Suppose finally that this commission recommended a ban on new billboard construction for ten years, that the city did nothing to investigate or analyze this recommendation, that it became law, and then was challenged by Omni.

Our hypothetical regulatory scheme could not survive application of the nondelegation principles embodied in the Court's active supervision requirement. In Ticor's terms, the construction ban would be subject to antitrust scrutiny because the city would not have "played a substantial role in determining the specifics of the economic policy." 288 Why should the analysis applicable to our hypothetical be any different given the actual facts of $O m n i$ ? The democratic process the Court seeks to protect through the active supervision requirement is equally undermined by the agreements protected in Omni as by the delegation condemned in Ticor. The existence of bribery statutes, which have never been perceived as chilling legislative behavior, illustrate the point. The Court said nothing new when it argued that bribery statutes are unrelated to the goals of the antitrust laws. That is of course true. But the consistent rule of the antitrust state action cases has been 
to judge the state action at issue against the Court's standards of governance, as in Ticor. If legislative action does not pass muster under those standards, then antitrust is normally allowed free
reign.

The notion that the governance principles of Ticor have a place in Omni brings up a second point-the Court's reluctance to engage in an analysis of subjective legislative intent. One difference between Omni and the Ticor-style cases is that in the latter cases the Court considers the structure of a regulation and the state's action or inaction in supervising the program. Both those elements are, relatively speaking, objective historical facts from which the Court may conclude that a state either did or did not relinquish its power of governance to private actors. When the anticompetitive state action at issue is a direct action such as a statute, the inquiry is harder. The Court then must determine if in passing the statute the state in fact relinquished its power of governance. All the facts Omni emphasized before the Courtthe longstanding ties between Columbia Outdoor and the city, the free billboard space, and the jury's finding of agreement between the council members and the company-were relevant because they suggested that the purpose of the billboard regulations was to secure Columbia Outdoor's monopoly. If that were true, the analogy between the direct action in Omni and the indirect action in Ticor would be sufficiently strong that one would expect the Court to reach the same result in both cases.

The Court, however, desired to avoid the type of inquiry that would provide information relevant to determining the true purpose of regulations like those in Omni. The Court has recognized that subjective legislative intent is relevant to at least a few areas of law, notably the First Amendment's Speech Clause and the Equal Protection Clause, and that in those areas it traditionally

289. The Omni Court's attention was diverted from the principles of governance it generally employs in these cases because, on the particular facts of the case, the violation of these principles and the alleged antitrust violation stemmed from the same behavior and went by the same name-conspiracy. In fairness to the Court, the blurring of the antitrust and governance issues was almost inevitable because the case had been tried on a conspiracy theory below. City of Columbia v. Omni Outdoor Advertising, Inc., 566 F. Supp. 1444 (D.S.C. 1983). That choice by the plaintiff, and the trial judge's failure to separate the two questions, meant that the questions were inextricably intertwined before the Court. But up the city government. Omni, $111 \mathrm{~S}$. Cl. at 1353 . examines the reasons a law was passed. ${ }^{290}$ The Omni Court rejected such an inquiry in the antitrust context, however, because "where the action complained of ... was that of the State itself, the action is exempt from antitrust liability regardless of the State's motives in taking the action. ${ }^{291}$

The Court's disavowal of an intent-based inquiry seems inconsistent with other state action cases, in which the validity of a state law is judged in part by whether the legislature has "clearly stated" its purpose in passing the law. The clear statement requirement is a form of intent inquiry, conducted through the mechanism of an irrebutable presumption, that forces state legislatures openly to avow any anticompetitive purposes they actually wish to achieve. A legislative confession of anticompetitive purpose is deemed sufficient and, more importantly, necessary, to protect an anticompetitive legislative program. ${ }^{292}$ Anything else, whether it be a statement of a different purpose, silence, or ambiguity, is in effect conclusively presumed to be a confession that the legislature did not intend to create a program inconsistent with the antitrust laws. Actions taken pursuant such a program are thus denied state action immunity.

The inquiry dictated by the Court's previous decisions would be focused on determining whether the legislature had in substance chosen to turn over the legislative keys to Columbia Outdoor for purposes of billboard regulation. That is a familiar inquiry undertaken in bribery cases, among others. ${ }^{293}$ The Court misapprehended the significance of the analogy to bribery statutes, however. Bribery will not tell us whether a statute is "in the public interest" because, as the Court rightly noted, legislators may take bribes to cast votes they would have cast for free. ${ }^{294}$ Rather, bribery statutes are significant in this context for two reasons. First, the existence of such statutes confirms our intuitive sense that the government acts illegitimately, in terms of fundamental democratic principles, to the extent that it barters its powers to private parties. Ticor made a similar point. ${ }^{295}$

290. Omni, $111 \mathrm{~S}$. Ct. at 1352 n.6. For cases in which the Court recognized subjective 290. Omni, 111 S. Ct. at 1952 n.6. For cases legislative intent in Spect

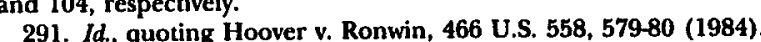

291. Id., quoting Hoover v. Ronwin, 466 U.S. 558,5
292. See supra note 244 and accompanying text.

292. See supra note 244 and accompanying text.
293. See, e.g. United States v. Jannotti, 673 F.2d 578, 601 (3d Cir.)(en banc), cent. de 293. See, e.g., United States
nied, 457 U.S. 1106 (1982).

294. Omni, 111 S. Ct. at 1359.

295. Ticor, 112 S. Ct. at 2178. 
Additionally, the existence and enforcement of laws against bribery provide reason to believe that legislators' actions may be subjected to judicial scrutiny without overdeterring legislators. The argument has an intuitive appeal because we can take it as a given that legislators are fully aware of the impropriety of ac cepting bribes, then there is nothing of the impropriety of acwrong with holding them point that there are point that there are well-recognized limits on permissible legislarease ber in all contexts, antitrust or otherwise. There is no reatson an antitrust suit should not be allowed to proceed once aries have been crossed.

This point leads to the final one: The Court's decision effectively placed all direct state restraints beyond antitrust scrutiny. That decision was based on the Court's concern that a failure to clo so would deter legislative behavior, impairing the functioning of the very democratic principles it sought to enforce. ${ }^{297}$ But, to borrow from Justice Frankfurter, the Court burned the house to roast the pig. ${ }^{298}$ The existence of bribery and similar statutes regulating the behavior of legislators demonstrates that boundaries of permissible legislative behavior may be enforced without undermining the democratic process. There is no reason the Court could not have applied such standards directly in Omni, as it did
in Ticor. ${ }^{299}$

\section{Recommendations}

Virtually all regulation is anticompetitive in the sense that it seeks to displace the distribution of wealth wrought by competition. If the Sherman Act, with its national mandate for competitive markets, were applied to all state regulations it would pose a serious threat to the states' very existence as meaningful governmental entities. This is a subject of legitimate judicial concern. A sovereign that cannot implement its policies is not much of a sovereign. On the other hand, if there is no state program be296. While it might be argued that antitrust liability is harder to determine ex ante than
is bribery, the same argument cannot be nade for compaign fong legislators' intentions.

297. Omni, 111 S. Ct. at 1351

298. Butler vi. Michigan, 352 U.S. 380,383 (1957).

299. One diference between the two cases is that the Court has iself applied the mondelegation principles at work in the Tasar is that the Court has itself applied the with respect to direct legislative enactme Ticor cases for some time but has not done so might (temporarily) feel blindsided by the imposition of issue in Omni. Legislators thus noted above, part of the appeal of using bribery stards by the Court. As tive action was worthy or immunity is that it avoids such to determine whether a legisla- yond mere authorization of a private restraint of trade, the state is not fulfilling any substantive mission, nor is it fulfilling its presumptive role in the federal system. It is simply declaring through legislation that, at least for a certain group of constituents, the federal antitrust laws stop at its borders. This is certainly not what the Court (or anyone else for that matter) has in mind when it speaks of the states as sovereign regulators, and allowing liability for such open defiance does not threaten the proper role of states in the federal system.

Federalism is not simply an mandate for an undifferentiated preference for state over federal decisionmaking. ${ }^{300}$ Not since Spencer Roane has anyone considered every restriction on state authority by the federal government to be contrary to the principles of federalism. If the rejection of the Virginia and Kentucky resolutions at the bar of history is not enough to establish that proposition, ${ }^{301}$ the Givil War was. Rather, the fundamental principle of federalism at issue in the state action cases is the distinction between states (or local governments) acting in their governance capacity and those acting merely to barter private immunity from the antitrust laws. States are entitled to deference when they are pursuing a legislative program toward some policy end, but not when they are simply enacting without significant review the anticompetitive policies proposed to them by private actors who stand to benefit. ${ }^{302}$

How can one distinguish between actions that represent merely a brokering of governmental immunity and actions that

300. Some commentators have taken this view. See, e.g., Elhauge, Antitrust Process, supra note 99, at 676 ("[i]ndeed, federalism and anti-Lochnerism seem offended rather than furthered by an active supervision requirement that restricts a state's regulatory options and by a clear authorization requirement that turns antitrust courts into adjudicators of what are essentially issues of state administrative law").

301. These resolutions, it will be recalled, asserted that the states had the power to interpret the federal constitution for themselves. This idea had eminent supporters. Thomas Jefferson wrote the Kentucky Resolution, and James Madison the Virginia Resolution. See Dumas Malone, Jefferson and the Ordeal of Liberty ch. 25, at 401-07 (1962). Malone argues with some force, however, that these resolutions were more a reaction to the Federalist's efforts to eradicate the Republican party through the Sedition Act than a reflective statement of constitutional doctrine. Id. It is thus significant that not even these highly charged and partisan documents claimed that the states had the power merely to pass a law suspending the operation of a federal statute within its borders. although the power they did claim could easily be used to achieve similar results.

302. For this reason, we disagree with Professor Page's suggestion that state laws encouraging vertical agreements restraining trade are valid because they simply correct for See Page, supra note 164, at 622. The state "policy" in this instance ion of a federal law with which the sate (and Profespetion, but purely 
actually implement a policy? The (somewhat unsatisfying) anthe purpose and must engage in a case-by-case analysis of whether to confer immunity. The state action in deciding should be to apply the principe ultimate goal of this analysis cussed a democratic governance dissis: (1) whether At least four factors may be relevant to that analypolicy; (2) whether thernment has clearly stated the goals of its (3overnment actively supervises implefor initiating or facilititing (3) whether a private actor is responsible (4) whether the state law, or both; and petitors wither state policy discriminates in favor of certain competitors within a market at the expense of others.

Two of these factors can be found in the Court's existing state action jurisprudence, at least in some form. The clear statement and active supervision requirements are best read as substantive parameters imposed by the Court that effectively define legitimate anticompetitive state activity. The principles that determine where these parameters will be set are familiar, basic theories of governance. Prominent among these principles is the idea, plinly stated in Ticor, that "[s] tates must accept political responsibility for actions they intend to undertake." ${ }^{303}$ As a theoretical blame for the higher prices then know where to place the blame for the higher prices they were paying and be able to remnomic terms the boting to replace the right people. ${ }^{304}$ In economic terms, the Court is attempting to diminish the probability tate policies by will be rationally ignorant of anticompetitive state policies by decreasing the cost of discovering the existence quiricy and those responsible for it. The clear statement requirement serves this end by requiring the state to announce its what the to restrict output-it is easier for consumers to find out what the state is doing if the Court requires the state to tell them. is sufficient if antiont requirement is not particularly rigorous-it is sufficient if anticompetitive consequences are the "foreseeable result" of the state's announced program ${ }^{305}$ - but it clearly aims

303. Ticor, $112 \mathrm{~S}$. Ct. at 2178

304. Of course, one of the lessons of public choice theory is tat accoutabily is int perfect in the real world. Because of national consumer ignorance, collecility is im problems, and multidimensional voter choices, a legislature ignorance, collective action ticompetitive actions may still not be held liable for the consequences. measure which reduces the costs of voters informing consequences. Nonetheless, any costs of voters informing themselves is a step in the right 305. Omni, 111 S. Ct. at 1350 at enhancing consumer awareness that they are being charged extra by reason of a state program.

As Ticor suggests, the active supervision requirement makes it more difficult for the state to claim that a scheme was merely the product of some renegade private actors, or that the state was ignorant of what was going on. It also should serve to locate responsibility within the state bureaucracy for the higher prices consumers are paying. One could envision the active supervision requirement as a norm of deliberation requiring the states to $\mathrm{ab}-$ stain from freewheeling public choice brokering of interests in favor of a more deliberative civic republican model, though the Court has not gone that far. Even in the less idealized world of public choice, the active supervision requirement may "encourage" such deliberation by raising the costs to legislators of taking action to benefit a particular interest group. ${ }^{306}$

The third factor, the role of private actors in procuring state legislation, is borrowed from Professor Wiley ${ }^{307}$ Essentially, this inquiry focuses on the role the private actor plays in proposing and enabling the adoption of state or local laws or regulations that benefit that actor. A company that proposes and secures passage of a legal rule which benefits itself-as Columbia Outdoor Advertising did in Omni-is necessarily more suspect than a company which took no affirmative action to influence the state. Unlike Professor Wiley, however, one should not afford this factor determinative weight. ${ }^{308}$ Professor Wiley would deny immunity in virtually all cases in which a government action was the result of petitioning by an interested private party. He thus appears to foreclose the possibility that an anticompetitive regulation suggested by an interested party might be a good idea for some other policy reason. In practice, the result of Professor Wiley's approach is to abolish state action immunity entirely, and rely instead on the antitrust laws themselves and principles of causation to limit liability.

306. Just as the "clear statement" requirement may discourage legislators from acting in an anticompetitive fashion by increasing their accountability, so the "active supervi-
sion" requirement discourages such action by forcing the legislator to commit more resion" requirement discourages such action by forcing the legislator to commit more re-
sources on an ongoing basis to implement such a policy. As the legislator's costs of acting go up, the number of such anticompetitive actions should go down

307. See Wiley, Capture Theory, supra note 36, at 723-29.

308. As noted above, while Professor Wiley offers four factors to aid the courts in determining whether capture of a state actor has occurred. However, the first three of those factors simply inquire into whether the state action violates the antitrust laws. They are not terribly helpful, therefore, in determining whether immunity should be granted for
an antitrust violation. See supra note 161 . 
This section's more limited conception of this factor treats it instead as an affirmative defense, or a threshold requirement that must be met but will not alone justify a denial of immunity. Thus, if state action can be shown not to have been influenced by interested private actors, that fact will counsel strongly against a finding that the state was engaging in a brokering of immunity. This requirement may also have the salutary incidental effect of alleviating the concerns expressed by Justice O'Connor in Ticor Justice O'Connor's dissent in that case lamented the use of "an after-the-fact evaluation of a State's exercise of its use of "an powers" to impose liability on private acise of its supervisory state law as "extremely unf on private actors complying with a ing private parties liable unfair to regulated parties." ${ }^{309}$ But holdresponsible for promulgaks far less unfair if they are in fact them.

the regulation that now binds

The final factor in this section's analysis is to determine whether a regulation discriminates among producers within an industry. State laws that prefer one competitor over another are significantly more likely to be the result of brokering than more general, or at least even-handed, laws. This is particularly true in combination with the third factor-when a particular company is responsible for enactment of a law that benefits that company at the expense of its competitors, the antitrust laws have great reason for concern. Again, the city council ordinance in Omni is a good example. Not only is a discriminatory law more likely to be the result of capture, but it is less likely to have some legitimate governance purpose behind it than a law of general applicability. This factor is in essence a type of fit analysis, which works from the premise that the purpose that fits the terms of a statute most closely is likely the purpose that generated it ${ }^{310}$

\section{Noerr As A First Amendment Doctrine}

The preceding section established that the antitrust laws are not the source of state action immunity; this section will draw on many of the same arguments to establish that those laws have

309. Ferleral Trade Comm'n v. Ticor Title Ins. Co., 112 S. Ct. 2169, 2184 ject to injuntions, J., dissenting). We note in this regard that local governments are subPetrofina, 501 F under the antitrust laws, but not damages. See New Mexico v. American law $101-103$ (1978). States, of course, I Pitt.lur AREeda \& Donald TuRner, Antitrust entl, Amendment. See Edelman $v$. Jo, immune from damages liability under the Elev-

310. See E1.Y, supra note 242, at 126 . 415 U.S. 651, 668 (1974)

even less to do with petitioning immunity. Instead, petitioning immunity is grounded in First Amendment principles protecting the freedom of speech and the freedom to petition the government for redress of grievances. The conclusion that petitioning immunity must be understood as a First Amendment doctrine is not new, ${ }^{311}$ which is not to say that it has not been the subject of dispute. ${ }^{312}$ The problem is that the analysis has usually stopped upon concluding that free speech is involved. The same is true of the Supreme Court, which has never explained why either the Speech or the Petition Clause shields a given activity from antitrust liability, although it has dismissed lawsuits on those grounds. ${ }^{313}$ Not surprisingly, lower courts have mostly ignored the question as well. ${ }^{314}$

This cursory analysis has led to some unusual results. Perhaps most prominent is the Court's conclusion that the rights of petition and association confer upon the citizenry the right to "use the channels and procedures of state and federal agencies and courts to advocate their causes and points of view respecting resolution of their business and economic interests vis-a-vis their competitors." ${ }^{15}$ Does this mean that the role of judges is akin to that of congressional representatives or the head of the Federal Energy Regulatory Commission? ${ }^{316}$ Is there a difference between the First Amendment protection accorded petitioning a legisla. tor and that accorded an ad campaign, such as the one run by

311. As we have noted, Professor Fischel was an early and prominent advocate of this view. See Daniel R. Fischel, Antitust Liability for Attempes and prominent advocate of this Basis and Limits of the Noer-Pennington Doctrine, 45 U. Cur. L. REv. 80, 81-84, 94 Action: The Other commentators have taken a similar view. See, Cis. L. Rev. 80, 81-84, 94-96 (1977). James D. Hurwitz, Abuse of Governmental Processes, the First Arland, supra note 47 at 512-16 Noerr, 74 GEo. L.J. 65, 66 (1985); Note, Noerr-Pennington Immunity, and the Boundaries of Under Clipper Express v. Rocky Mountain Motor Tarif Bureau, Inc.: Replacing Antitrust Liability with a Constitutional Analysis, 69 CoRNELL L. REV. 1305 (1984). Replacing the Sham Exception 312. For other views, see,

14-16 (Supp. 1991); Calkins, Developments in Antitrust and hoventasm, Antrtrust LaW gation of Noer, 57 ANTITRUST L.J. 327, $346 \mathrm{n} .96$ (1988) (collecting Amendment: the Disaggre tors); Note, Allied Tube $\mathcal{E}^{\circ}$ Conduit Corp n.96 (1988) (collecting cases and commentaFramework for Claims of Noerr Immunity, $41 \mathrm{~S}$. CAl. I. Head, Inc.: An Emenging Conceptual 313. Professional Real Fstate

(1993) (affirmingal Real Estate Investors v. Columbia Pictures, Inc., 113 S. Ct. 1920 (1993) (affirming grant of summary judgment in favor of defendants on counterclaim

314. Eg.. Sessions Tank Liners, Inc. v. Joor Manuf., Inc., No. 92-55085 (9th Cir. Febru-
ary 15, 1994) (defor ary 15,1994 ) (defendant immune from liabillty for misleading standard-setuing organiza315. Califoring anticompetitive restriction in organization's fire code).

315. California Motor Transport Co. v. Trucking Unlimited, 404 U.S. 508 (1972).

316. In some cases, the Court apparently does means that. Insofar as the Voting Rights
Act is concerned, for example state court judges an Act is concerned, for example, state court judges are "representatives" of the people. See
Chisom v. Roemer, 111 S. C.. 2354 (1991). 
the Eastern Railroad Presidents Conference? Why isn't the filing of a rate with a state agency, such as in Midcal, 324 Liquor Corp. and Ticor, "petitioning" and therefore immune from liability? The Court's approach to the Noerr doctrine has not provided a framework for answering any of these questions. This section describes a conceptual approach, grounded in the First Amendment, to Noer immunity.

The Speech Clause of the First Amendment has received considerably more attention than has the Petition Clause, probably because almost anything one could do to petition the government would necessarily take the form of communication protected under the Speech Clause. If campaign contributions ${ }^{317}$ and nude dancing ${ }^{318}$ are protected speech, the clause would surely encompass a letter to or a meeting with one's senator. Petitioning is an example of what the Court generally refers to as "core" speech, or speech "at the heart of the First Amendment"-speech about politics and the operation of the government. ${ }^{319}$ We are thus fairly safe in applying the familiar principles of free speech jurisprudence to the problems raised in the cases following Noerr. ${ }^{320}$

As a practical matter, it is important to understand the realworld effects of the type of speech that is challenged in cases under the Noerr doctrine. Often the speech at issue will combine unquestionably protected characteristics and some characteristics that are of valid regulatory concern, which for our purposes generally take the form of costs imposed on competitors. In Noerr, for example, the railroads' publicity campaign allegedly interfered with the truckers' relationship with their customers. ${ }^{321}$ In other cases, petitioning has slowed regulatory approval of an application to do business or to sell bonds. ${ }^{322}$ The question is

317. Buckley v. Valeo, 424 U.S. 1 (1976).

318. Barnes v. Glen Theater, 111 S. Ct. 2456 (1991)

319. See, e.g., Hustler Magazine v. Falwell, 485 U.S. 46, 50 (1988) (holding that New York Times rule structure applies to actions by public figures for intentional infliction of emo-
tionial distress).

320. Cf. McDonald v. Sinith, 472 U.S. 479, 482 (1985) ("The right to petition is cut from the same cloth as the other guarantes of that amendment, and is an assurance of a particular freedom of expression."). In McDonald, the Court held the rules governing libel petition the government. The Court went 376 U.S. 254 (1964), also applied to efforts to inspircel by the same ideals of liberty and on to conclude that the Petition Clause "was publish, and assemble" and of "ity and democracy that gave us the freedoms to speak, Donald, 472 U.S. at 485 (citation omited). 321. 365 U.S. at 129 .

322. These cases are discussed in the text accompanying notes 344-348, infra. whether, and, if so, how, such anticompetitive consequences may be redressed consistently with the First Amendment.

\section{A. The Uneven History of the Essential Dissimilarity Rationale In Petitioning Immunity Cases}

As discussed in Part II, Noerr and subsequent cases have asserted that there is an "essential dissimilarity" between petitioning activity and the evils the antitrust laws were designed to prevent. The Omni Court characterized the state action and petitioning cases as embodying the principle that the antitrust laws "regulate business, not politics." Court in Noerr to cast its decision as an interpretation of the antitrust laws rather than as a construction of the First Amendment. Had the activity in Noerr not been held essentially dissimilar to activity covered by the Sherman Act, the Court would have had to resolve the constitutional issue directly, because the activity in that case was unquestionably speech within the meaning of the First Amendment. ${ }^{324}$ The Court's methodology deprived the doctrine of the clarity that a frank discussion might have produced.

In practice, the Court's reliance on the essential dissimilarity doctrine has been inconsistent. In several cases, the Court has appeared to rely on the First Amendment to the exclusion of the essential dissimilarity rationale. This approach was most evident in California Motor Transport Co. v. Trucking Unlimited, ${ }^{325}$ where the Court appeared to back away from the statutory interpretation theory of Noerr, and to engage in an openly constitutional analysis. In California Motor Transport, the Court identified only two grounds for Noerr - the need for the government to receive information in a representative democracy, and the First Amendment. ${ }^{326}$ Further, the Court rested its holding, that Noerr applies to attempts to petition agencies and courts, squarely on the First Amendment rights to associate and to petition. ${ }^{327}$

Many of the Court's more recent cases demonstrate a similar analysis. In FTC v. Superior Court Trial Lawyers' Association, ${ }^{328}$ the Court read Noerr as a case "[i]nterpreting the Sherman Act in

323. City of Columbia v. Omni Outdoor Advertising, Inc., 499 U.S. 365, 383 (1991).

324. See infra text accompanying notes $422-428$.

325. 404 U.S. 508 (1972)

326. Id. at 510 .

327. $I d$. at $510-11$

328. 493 U.S. 411 (1989) 
light of the First Amendment's Petition Clause, ${ }^{329}$

ignoring the essential dissimilarity ration Clause, ${ }^{329}$ completely would have provided an dissimilarity rationale even though it signal article on the soure ${ }^{330}$ In his chel gave the essential disimila Noerr doctrine, Professor Fisjecting it in a single palial dissimilarity rationale short shrift, reapplied the principle inconsisten ${ }^{331}$ He noted that the Court has efforts but not others 332 sistently, protecting some petitioning

One should

essential dissimilarity rationale from these cases, however, that the essential dissimilarity first as a justead. The Court again ranked decision in Professional Real Estustification for Noerr in its 1993 Inc. ${ }^{333}$ There the Columbia Pictures, punish political activity stated that "the Sherman Act does not the government of their wishe w334 the people freely inform one grounded in the ernment's power to act in First Amendment right in its representative capacity" and "the district rationale in circuit courts have relied on the essential dissimilarity decisions the anticompetitive act petitioning that really was dissimilar to

329. Il. at 424

330. The defendants in SCTIA were criminal deferse bayes w

ligher prices for their services. This is a form defense lawyers who agreed to charge

essentially dissimilitr to an antitrust viobation.

331. Fischel, supra note 311, at 83 .

392. Id.

333. 113 S. C. 1920 (1993)

334. It. at 1926 (quoting Noer, 365 U.S. at 129).

335. It.

(ii. 1992) (holdling that Organization for Women v. Scheidler, 968 F.2d 612, 620-21 (7th hrought against anti-abortion men's health care centers providing for alleged nationwide conspiracy to close all wofor Women, 620 F.2d 1301, 1312-13 (8th Cir. 1980) (h); Missouri v. National Organization influence state legislature's actions by org. 1980) (holding that defendant's campaign to scope of the Sherman Act) in re Airporanizing at convention boycott was beyond to 568, 575 (N.D. Cal. 1981) (he officials to act was beyond the scope joint activity of defendants in encouraging public taken this view as well. See, e.g Scope of the Sherman Act). Many commentators have the Noer-Pennington Impunity., Stanley E. Crawford, Jr. \& Andy A. Tschoepe, The Erasion of DeScvo, The Noerr Doctrine and its Shan Excep.j. 291 (1981); Milton Handler \& Richard af The Misapplication of the Noer Pents Sham Exception, 6 CARDOzo L. REv. 1, 3-5 (1984). Note Stran. L. Rev. 1243, 1250 Pennington Doctrine in Non-Antitrust Right to Petition Cases, 36 (1988) (vicwing Noerr as a statutory (1984). Cf. Calkins, supra note 312 , at 346 , 96 337. For example a statutory interpretation doctrine with a constitutional "core") aging organizations selectin $v$. NOW involved a challenge to NOW's practice of ence Equal Rights Amens stecting convention sites to boycott states that had not passed the

those decisions treated the essential dissimilarity rationale as broadly applicable to all petitioning cases. ${ }^{398}$

\section{B. The Anticompetitive Effects of Petitioning}

The essential dissimilarity doctrine might be based on one of two different rationales. ${ }^{939}$ First, it might mean that petitioning is not subject to antitrust liability because petitioning does not have, as a matter of law, the anticompetitive purpose required to impose liability under the antitrust laws. This interpretation would make sense if petitioning immunity were grounded in the antitrust laws themselves. In that case, the petitioning immunity would simply be an interpretation of the scienter requirement of the antitrust laws; no separate doctrine would be necessary. The problem with this interpretation is that its premise is demonstrably false. The railroads in Noerr had an avowedly anticompetitive purpose, as did the trucking firm in California Motor Transport, and the billboard company in Omni. The jury's finding of liability in that case necessarily entailed a finding of anticompetitive intent.

The second possible rationale is that petitioning simply does not have, as a matter of law, the kind of anticompetitive effects required to support liability. This interpretation again would base petitioning immunity in a construction of the antitrust laws. There is intuitive appeal to the idea that petitioning lacks the requisite anticompetitive effect to support liability. It is common knowledge that firms often act with the intent to invoke the government's resource reallocation power in their favor, and that such reallocations are inefficient. ${ }^{340}$ But to many, the mere process of petitioning seems to be a far cry from actually rigging a price. That impression is misleading.

Rescue," alleging that group had violated the antitrust laws by seeking to drive abortion clinics out of business. $765 \mathrm{~F}$. Supp. at 938 . In both cases, commercial motivation is entirely lacking - the petitioners are merely using economic means to pursue an unrelated political or moral objective.

338. See Missoun v. NOW, 620 F.2d at 1312-13; Scheidler, 765 F. Supp. at 939-40 (both reading Noer as applying to all political petitioning, while concluding that the conduct before them was more dissimilar to the antitrust laws than that in Noerr).

339. Just as with the state action doctrine, Professor Elhauge discerns a third dissimilarity between petitioning and the types of conduct the antitrust laws were designed to prevent. That dissimilarity relates to the process differences between petitioning and other private action. See Elhauge, Petitioning Immunity, supra note 178, at 1177. We discuss Professor Elhauge's theory in detail at the end of this Section.

340. See supra section II. A. discussing the anticompetitive consequences of state action. 
As a practical matter, a petitioner's efforts must be matched by its rivals if they are to avoid harmful government action. Matching these efforts raises the rivals' costs, which can render rivals less competitive in the market. ${ }^{341}$ The railroads' advertising campaign in Noerr, for example, had to be matched by the trucking industry. ${ }^{342}$ Campaign contributions or other lobbying expenditures also must be matched. Finally, filing a lawsuit, which counts as petitioning under the Noerr doctrine, can entail enormous costs for the defendant, not the least of which is that a defendant must hire an attorney and respond to the complaint or suffer a
default. ${ }^{343}$

Additionally, pending litigation or agency proceedings may cause problems for rivals outside the courtroom. These can range from the substantial costs of diverting management from productive activity and of engaging in discovery to indirect impediments to a firm's business. ${ }^{344}$ Perhaps the best example of this is the famous Otter Tail case, in which a private utility with a monopoly over electricity thwarted the efforts of certain municipalities to construct their own utilities by filing lawsuits that impaired the municipalities' ability to sell bonds to finance their proposed plants. ${ }^{345}$ The pending litigation slowed or stopped bond sales altogether because the bonds covenanted that no litigation was pending regarding the uses to which the bond proceeds would be put. As Otter Tail demonstrated, pending litigation can increase the riskiness of any new venture, and thus increase its cost of capital.

Admittedly, petitioning will not always be an effective anticompetitive tool. Petitioning might backfire in some cases, imposing higher costs on the petitioner than on its competitors. Petition-

341. See, e.g., Krattenmaker \& Salop, supra note 133, at 242-48 (explaining how raising pricing). pricing).

342. Eastern Railroads Presidents' Conference v. Noerr Motor Freight, 365 U.S. 127,
130-31 (1961). 343. See, e.g. Premier Elec. Constr. Co. v. National Elec. Contractors, 814 F.2d 358, 376
(7th Cir. 1987) (discussing how the costs of defending against litigation may be used anticompetitively); Janet Cooper Alexander, Do the Merits Matter? A Study of Settlements in Securities Class Actions, 43 STAN. L. REv, 497, 566-67 (1991) (noting that securities plaintiff file suit without regard to the merits, because defendants will seule even baseless suits rather than pay the costs of litigation).

344. The authors can attest from painful personal experience that discovery may entail
he photocopying and review of literally millions of the photocopying and review of literally millions of documents for weeks on end. It is not unusual for litigation to comprise one of the largest monthly costs of even very large
companies.

345. Otter Tail Power v. United States, 410 U.S. 366 (1973). 
that they, and no one else, get the available benefits. Rent-seek ing describes the tendency of private firms collectively to spend the value of the benefit offered, or perhaps even more than that
value, by competing for it.

Suppose several firms wish to obtain the same government benefit, and that each is willing to spend up to the value of the benefit to get it. ${ }^{352}$ In that case, the total amount spent on petitioning to obtain the benefit might far exceed the value of the benefit itself. ${ }^{353}$ If this seems counterintuitive, or if the reader 351. Not all rent-seeking is bad. Some such efforts are to be encouraged because they
hate positive side effects. For example, a group of firms seeking a govern patcht monopoly will compete for it by developing innovations a government-provided competitors. While duplicative investment in a so-called "patent race" quickly than their able, it does benefit society by speeding up the innovation processe" is often undesirduce valuable "spin-off" inventions. See generally Mark F. Grady \& Jay I Alexander ProL.aw and Rent Dissipation, 78 V. L. Rev. 305, 315 (1992); Robert P Jay I. Alexander, Patent the Patent District: Observations on the Grady-Alexander Thesisert P. Merges, Rent Control in (1992).

352. This is a fundamental assumption of rational behavior in econon COOTEK \& UI.EN, supra note 122, at 95-97. Actually, the sehavior in economic theory. See inaccurate. Firms will be willing to pay up to the expected uatuent in the text is technically expected value of a benefit to a risk-neutral decision-maker is of the benefit to them. The times the percentage chance that the firm will get the ber is the value of that benefit, $V$, $c_{1} V_{1}$. The total all firms should be willing to

353. See Dennis Muflak, Public Croice pay, $T$, therefore equals $\Sigma_{1}$ "cV.

Rent Serking, in Janes M. Buchianan ET Al., TowapD a (1989); Gordon Tullock, Efficient FTY 97-112 (1980). Specifically, in the sinipleward a THEORY Of THE RENT-SEeking Socifirms in the industry competing for the benefit $T$ benclit are each willing to $\$ 10,000$, a sum far in excess of the vap to $\$ 1,000$, then in the aggregate they will spend The reader might imess of he value of the benefit.

spend more than $c V$, and $\Sigma_{i}{ }^{\circ} c=1$. For exam, given perfect information, no firm will percent chance of recciving a benelit. If every firm accurg a $\$ 1,000$ benefit will spend only $\$ 100$ towards receiving would not excecd $\$ 1,000$. \$1,000.

ties in the agrethate $\$ 1,000$ would be inefficient from a societal perspective, because the parmake spending in would have wisted the entire value of the benefit. But two factor excorenous ving excess of cV likely, and thus even more inefficient. First, $c$ is not an its $c$. lebsying (beal world) legislators respond can increase lo iufle $=x+r T_{1}$, where $x$ is the exogenous value of $c$, and $r$ is a function a linear func$\left.T_{1}\right) V$. prak , ant practice, suppose that the total benefit sought $(V)=\$ 1000$, that the endogenous in recciving the bencfit ( $c$ in the original fornula, $x$ in the subsequent initial chance of that $r=.0005$. In our initial formula, firm 1 would spend up to $c V$; that is, up to $=.1$, and \$100. Under the new formula, however, it will spend up to $\mathrm{xV}$-( 1 - rV is, up to .1 ( $\$ 1000)$ $.0005(\$ 1000))=\$ 200$. Thus, even with very small values of $r$ (reflecting a $1(\$ 1000)$-( 1 ence of expenditure on outcome), the amount each firm will a mininal infludramatically.

Second, the firms in our example not only desire the benefit for themselves, but seek to
deny it to their competitors. This makes ing are government-sanction This makes sense, particularly if the benefits we are discussing are government-sanctioned monopolies or cartels or preferences which raise their
competitors' costs. In effect, rent seckers in our example are risk preferential. $C f$. Arye $L$.

wishes to avoid the math in the footnote, think of government restraints on competition as an auction. Private firms "bid" by lobbying the government, and the highest bidder wins the re straint. Unlike a normal auction, however, bidders have to pay regardless whether they win or lose. The result is that bidders-the private firms-spend far more as a group than any one of them thinks the government benefit or restraint is worth. ${ }^{354}$ This excess spending is a major inefficiency associated with petitioning. ${ }^{355}$

Rent seeking occurs in a number of different contexts in the real world. Regulated industries (and sometimes consumer groups as well) ${ }^{356}$ will fritter away the social surplus in an attempt to influence the decisions of regulators. ${ }^{957}$ Domestic industries will compete for protective tariffs and quotas. ${ }^{358}$ And govern-

Hillman \& Eliakim Katz, Risk-Averse Rent Seekers and the Social Cast of Monopoly Power, 94 ECON. J. 104, 110 (1984) (noting that risk aversion reduces total rent seeking; and sug-
gesting that risk preference would have the opposite effect). Thus, nents, the (positive) value of receiving the benefit ( $V$ ) and the (nus, $V$ has two compoit $\left(V_{L}\right)$. Thus. $E V=c V_{r}-(1-c) V_{L}$. The fear of losing the benefit to a competilue of losing firms willing to spend more than they otherwise would the benefit to a competitor makes $c=.1, V_{r}=\$ 1,000$, and $V_{L}=\$ 250, E V=.1(1000)-9(-250)=100-(-225)=\$ 925$. example, a firm which would spend only $\$ 100$ to $-.9(-250)=100-(-225)=\$ 325$. In this $\$ 925$ in order to deny the benefit to only $\$ 100$ to get the benefit for itself will spend up to In combination, of course, the

mulae for risk aversion and feedbacks are even more powerful. Combining the forAlgebraic manipulation and feedbacks yields $T_{1}=\left(x+r T_{1}\right)\left(V_{r}\right)-\left(1-\left(x+r T_{1}\right)\right)\left(V_{L}\right)$ to use the numbers demonstrates that $T_{1}=\left(V_{L}-\left(V_{r}+V_{L}\right)(x)\right)-\left(\left(V_{r}+V_{L}\right)(r)-1\right)$. Thus $1)=\$ 520$. In other words, examples above, $T_{i}=(-\$ 250-(\$ 750)(.1))-((\$ 750)(.0005)$ tially has only a re move here, a firm which ini( of the benefit in an attempt to obtain it.

354. Interestingly, the corollary is that the prevailing firm pays less than it thinks the
benefit is worth. This follows because firs

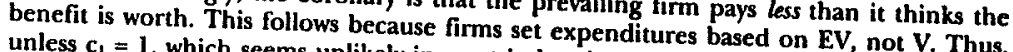
unless $c_{1}=1$, which seems unlikely in most industries, the ultimately successful firm will
have invested less than it was willing to pay for the bention 355. Estimates of

surplus sought to several times the seeking range from roughly 20 percent of the social 231-38; Hillman \& Katz, supra note 353, at the surplus. See MuELLER, supra note 353, at tion of Contestable Rents by a Small Number of 105-07; Arye L. Hillman \& Doc Samet, DissipaRichard A. Posner, The Social Costs of Mer of Contenders, 54:1 PuB. CHorce 63, 79-82 (1987); (1975).

356. See Sam Peltzman, Toward a More General Theory of Regulation, 19 J.L. \& Econ. 211 wealth redistribution a through of optimum size for effective political coalitions that seek 357. For an explation process).

357. For an explanation of why this happens even if only one party is "competing" for
the benefit, see George Stigler. The Theory SCI. 3 (1971). For an effort to estimate the losses due Regulation, 2 BELLJ. Econ. \& MGMT. Posner, supra note 355 , at $815-25$.

358. See MUELLER, supra note 353, at 238-42; cf. Howard P. Marvel \& Edward J. Ray, The
Kennedy Round: Evidence on the Regulation of ECON. Rev. 190 (1983) (providing indirect In 

ment contracts will encourage rent-seeking by those who wish to
be awarded the contract.

As we have seen, both state action and private petitioning designed to secure such action present real threats to competition and efficiency. Far from being essentially dissimilar to antitrust violations, petitioning is directly related to actions with which the antitrust laws are very much concerned. The question then becomes why anticompetitive petitioning should be tolerated at all, at least when the anticompetitive consequences are significant enough to be material for purposes of the Sherman Act. The answer is that it should not be, unless some legal rule superior to the Sherman Act compels the abeyance of the antitrust laws. The First Amendment is such a rule, and is in fact the only basis for excepting anticompetitive petitioning from Sherman Act liability. It follows that petitioning protected by the First Amendment should be immune from antitrust liability, while petitioning not protected by the First Amendment may serve as the basis for antitrust liability.

\section{Petitioning Immunity as a First Amendment Doctrine}

Two First Amendment principles are relevant in determining the scope of petitioning immunity. The first is the public forum doctrine, which identifies governmental resources with which the right to petition can validly be exercised. The public forum doctrine gives extremely broad latitude to petitioners in some fora, such as holding a political rally in a public park, and virtually no protection in other fora, such as picketing on prison property $\mathbf{3 6 0}$ and soliciting in employee mailboxes. ${ }^{361}$ The protection given to petitioners in other fora, including courts and administrative agencies, falls somewhere between the two extremes.

The second principle relevant to determining the scope of petititoning immunity is the deterrence theory the Court used in Omni. That Court relied on the "chilling effect" rationale which has been used in a number of specific First Amendment con-

\footnotetext{
359. See, e.g., Peter M. Aranson \& Peter C. Ordeshook, Spatial Strategies for Sequential Lilertions, in Probability Models of Collective Decision-MaKing 298 (1972) (suguential methods of choosing campaign strategy to maximize joint probabilities of nomination and election); Gordon Tullock, The Cost of Transfers, 4 KrkLos 629 (1971) (asserting that even the possibility of transfers imposes significant costs on society). 360. Adderley v. Florida, 385 U.S. 39 (1967) (sustaining convictions for trespassing on
prison grounds during demonstration).

ing that public school teachers' Local Educators' Ass'n, 460 U.S. 37, 45-46 (1983) (holding that public school teachers' mailboxes are not public fora).
}

texts-such as the libel laws-to promote robust and freewheeling speech and debate by creating a buffer zone of immunity from liability for speech that might otherwise be foregone by a risk averse speaker. ${ }^{362}$

The First Amendment compels a distinction in the Noerr cases between petitioning Congress or a state legislature and "petitioning" a court or administrative agency in an adjudicatory proceeding. Petitioning is entitled to broad protection under the First Amendment, and thus is entitled to immunity from liability under the antitrust laws, when it takes the form of a publicity campaign to persuade the legislature to take action, as in Noerr, or of a direct appeal to the legislature. A lesser degree of protection is warranted for petitioning administrative agencies engaged in rulemaking proceedings. Petitioning is not entitled to such broad immunity when it takes the form of a lawsuit or a filing in an adjudicative proceeding. It follows that antitrust laws should apply fully in such cases, assuming the other requirements of an antitrust claim are met and liability imposed.

\section{The Structure of Government And Some Premises for Petitioning}

Perhaps the classic conception of the relationship between the citizen and the state underlying the First Amendment is Justice Brandeis's famous concurrence in Whitney $v$. California. ${ }^{363}$ Justice Brandeis contended:

Those who won our independence believed that the final end of the State was to make men free to develop their faculties; and that in its government the deliberative forces should prevail over the arbitrary. They valued liberty both as an end and as a means. They believed liberty to be the secret of happiness and courage to be the secret of liberty. They believed that freedom to think as you will and to speak as you think are means indispensable to the discovery and spread of political truth; that without free speech and assembly, discussion would be futile; that with them, discussion affords ordinarily adequate protection against the dissemination of noxious 362. Cf. New York Times Co. v. Sullivan, 376 U.S. 254 (1964)(holding that the First
Amendment bars a civil libel judgment for criticism of public officials in respect to their official conduct unless the plaintiff shows "actual malicen" by clear and convincing
evidence) evidence).

363. 274 U.S. 357 (1927) (Brandeis, J., concurring).

364. Id. at 375 . 
The Framers might well have been surprised to hear what Justice Brandeis thought they thought. Those imprisoned under the Sedition Act, ${ }^{3655}$ passed and enforced by "those who won our independence," would surely be even more surprised. Justice Brandeis's model is, however, a fair description of First Amendment doctrine beginning with New York Times v. Sullivan, ${ }^{366}$ which belatedly struck down the Sedition Act and gave extensive protections to political speech about public figures. But the New York Times rule's structure does not and cannot cover the full range of speech the Court has decided falls within the protection of the First Amendment. ${ }^{367}$ The Noerr problem provides an excellent example, especially as it has been extended to the "petitioning" of courts and administrative agencies. To understand the considerations that must be taken into account, it is first useful to unclerstand what Justice Brandeis had in mind when he wrote his description of the scope of the First Amendment.

Instead of the Framers and Revolutionary War veterans, Justice Brandeis reached further back in history, to Athens of 450 B.C. Brandeis's biographers and admirers contend that the quoted passage reflects Brandeis's admiration for Pericles' funeral oration rather than for the Framers of the United States Constitution. ${ }^{36 i 8}$ The Athens described in Alfred Zimmern's The Greek Commonweallh, ${ }^{369}$ reportedly Justice Brandeis' favorite book, could not be further removed from the America of 1927, to say nothing of the present. A theory of speech designed with such a society as a model is bound not to comport with modern society.

Brandeis attempted to fashion a theory of free speech in which the people participated actively in the government. Participation in the political life and governance of the state was, for the Athenians and for Brandeis, as much if not more a part of the citizens' life than the craft or trade in which one earned a living.

365. 1 Stat. At Large 596-97.

366. 376 U.S. 254 (1964).

367. For example, it would be hard to know how to apply the New York Times standard as applied to the nude dancers whose expression was assumed to be within the outer boundaries of the First Amendment in Barnes v. Glen Theater, 111 S. Ct. 2456 (1991). 368. See Antiony Lewis, Make No Law: The Suildvan Case and the First Amendment 87 (1901) (tracing the history of the Sullivan case and analyzing its effects on first amendment doctrine); Vincent Blasi, The First Amendment and the Ideal of Civic Courage: The Brandeis Opinion in Whitney v. California, 29 WM. \& MarY L. Rev. 653, 680-81 (1988) (linking the Brandeis opinion in Whitney to Pericles's funeral oration); Paul A. Freund, Mr. Justice Brandeis: A Centennial Alemoir, 70 HARv. L. REv. 769, 789-90 (1957)(address given at ceremony commemorating the 100th anniversary of Justice Brandeis's birth).

369. Ai.freis Zimmern, The Grefk Conmonweal.ti (5th ed. 1931).
The State was small enough, and the number of decisions was small enough, that it was possible for the Athenians to come closer to the democratic ideal than Americans could ever hope to come. As Zimmern noted, "The Greek City State differs from our modern democracies in enlisting not all but merely a far larger proportion of its representative in active public work. Whereas with us, however democratic our constitution, the few do the work for the many, in Greece the many did it for themselves." ${ }^{370}$ It is possible, in other words, to fit Brandeis's theories to a society in which 6,000 of the 40,000 citizens could be called for jury duty each day, ${ }^{371}$ or in which substantially all the citizens could come to a theater to hear argument and to deliberate on whether to go to war, to offer tribute, or to decide some other pressing question. ${ }^{372}$ The transaction costs of full citizen participation in, and thus constitution of, government were low enough to make the effort feasible.

Drawing on an Athenian model to give meaning to the First Amendment is bound to create problems for a modern society, however. In Athens, the problem of trying to broker a deal with a legislator, whose tenure is entrenched by contributions from political action committees and by plum committee assignments, simply did not exist as it does today. The theory animating Brandeis's vision of the First Amendment is simply inadequate to deal with modern problems. Entrenched bureaucracies, both independently and at the behest of legislators, dole out the government benefits that create the anticompetitive consequences of the Parker and Noerr cases. ${ }^{373}$ Clearly, as the size of the polis ex-

370. Id. at 160 .

371. This number was divided among different matters, so each jury consisted of "only" several hundred jurors. Zimmern states that no jury consisted of less than 201 jurors ZMMMERN, supra note 369 , at $162-63$.

372. This point should not be taken too literally. As Zimmern points out, and which we would know instinctively if he did not, "[n]o state has ever been composed of citizens all of whom have the leisure or the desire or the knowledge to attend to public affairs." Id. at 160. Citizens-meaning men over the age of 18 who owned property-were members of the parliamemt (Ecclesia) and could attend its sessions, voting on matters of policy. Id. at 159, 169. Zimmern estimates that the number of citizens was between 35,000 and 44,000 . 1d. at 174. According to Zimmern, other than on truly important occasions, it was difficul to get more than 5,000 in attendance. Id. at 169 . Still, having 5,000 of, say, 40,000 eligible attend is a representation radically different from 536 out of 250 million.

373. The Athenians had a permanent governing body known as the Council, comprised of $\mathbf{5 0 0}$ members. But this body was chosen annually by lot, and no citizen could si on it more than two times. Id. at 164. These qualifications greatly diminish the problem of entrenchment and self-perpetuating behavior with which much of the public choice literature is concerned. 
pands, the transaction costs of true self-governance quickly become prohibitive, even at a fairly local level.

We therefore must adapt our theories of speech and petitioning so that they work in a modern environment. For Congress, an administrative agency, or a court to work effectively, restrictions on speech simply must be imposed as necessary concomitants of a formal decision-making process. ${ }^{374}$ Fortunately, we have a substantial body of First Amendment cases from which we may draw the principles necessary to deal with the problem the Court created in Noerr and California Motor Transport.

The public forum doctrine provides the principles necessary to analyze the problems presented by Noerr. The Court has used the public forum doctrine to resolve conflicts between an asserted right to use a public resource for speech purposes and a governmental claim that nature of the resource compels a restriction on speech. The Court "adopted a [public] forum analysis as a means of determining when the Government's interest in limiting the use of its property to its intended purpose outweighs the interest of those wishing to use the property for other purposes." Under the Court's approach, "the extent to which the Government can control access depends on the nature of the relevant forum." ${ }^{376}$ The references in public forum cases to the "place" of the speech are simply a shorthand method of referring to the purpose to which a given resource is dedicated. ${ }^{377}$ Thus, while the public forum cases do not deal directly with administrative agencies, the doctrine offers principles with which to understand the Court's invocation of the First Amendment in Noerr and California Motor Transport.

The public forum doctrine divides the universe of governmental petitioning fora into three types: public fora, designated pub-

374. Alhens undoubtedly imposed some such restrictions within the Ecclesia, though the Athenians probably had less of a need for formal restrictions enforceable by, for example, pecuniany sanclions.

375. Cornelius v. NAACP Legal Defense and Educ. Fund, Inc., 473 U.S. 788, 800 375.
(1985). (1985).

377. Indeed, in Frisby v. Schultz, 487 U.S. 474, 479 (1988), the Court acknowledged this with its own quotation marks: "To ascertain what limits, if any, may be placed on protected speech, we have often focused on the 'place' of that speech considering nature of the forum the speaker seeks to employ." The focus of the public forum the nature of the forum the speaker seeks to employ." The focus of the public forum docert C. Post, Between Governance and rather than its location, is explored at length in Rob34 U.C.L.A. L. Rev. 1713 (1987). lic fora, and nonpublic fora. ${ }^{378}$ The second category has little if any substantive significance apart from the first. Whatever the Court's original intent, the difference between the two is now primarily chronological: public fora are such by virtue of history and tradition, and designated public fora are such because of a governmental choice to open them to the public. ${ }^{379}$ The government may only regulate speech in public fora, traditional or designated, if the regulations are "narrowly drawn to achieve a compelling state interest. ${ }^{\text {"380 }}$ In nonpublic fora, by contrast, government regulations "need only be reasonable, as long as the regulation is not an effort to suppress the speaker's activity due to disagreement with the speaker's view. ${ }^{\text {"381 }}$

The classic cases involving public fora concern demonstrations on public streets and sidewalks, such as a march on a public street near a courthouse, ${ }^{\mathbf{3 8 2}}$ and picketing on a public sidewalk in front of a doctor's home. ${ }^{983}$ These cases have given binding legal effect to Justice Roberts' famous assertion in his plurality opinion in Hague v. ClO that "streets and parks . . . have immemorially been held in trust for the use of the public and, time out of mind, have been used for purposes of assembly, communicating thoughts between citizens, and discussing public questions." ${ }^{\text {"384 }}$ There is no longer any dispute that "all public streets are held in the public trust and are properly considered public fora. ${ }^{385}$

Application of the public forum doctrine has not been limited to public streets and sidewalks, however. The more interesting cases have involved regulations of speech on property owned by the government and dedicated to a specific purpose, but nevertheless open to considerable use by the public. The Court has

378. See, e.g., Perry Educ. Ass'n v. Perry Local Educators' Ass'n, 460 U.S. 37, 45-46 (1983)

379. See Intermational Society for Krishna Consciousness v. Lee, 112 S. Ct. 2701, 2705 (1992) (sustaining and striking down regulations pertaining to solicitation in airports). 380. Id. at 2705. Although the Court was badly fragmented in ISKCON, Chief Justice Rehnquist wrote for a majority in setting forth the applicable standard of scrutiny, about which the parties agreed. Id. at 2706 (noting that parties did not dispute three-part division of fora or the attendant levels of scrutiny).

381. Id. at 2705-06.

382. See Cox v. Louisiana, 379 U.S. 586 (1965)

383. See Frisby v. Schultz, 487 U.S. 474 (1988).

384. 307 U.S. 496, 515 (1939).

385. See, e.g., Frisby v. Schultz, 487 U.S. 474 (1988). The Court's statement came in the course of rejecting an argument that quiet residential streets should not automatically be treated as public fora in the same way a major street would be. There may be some degree of protection for domestic tranquility through the application of restrictions on the volume or other aspects of a demonstration. See Kovacs v. Cooper, 396 U.S. 77, 86-87 (1949) (sustaining restrictions on the use of sound trucks). 
generally concluded such fora are not public, and has tolerated most regulations of speech in such places. Adderley $v$. Florida ${ }^{\mathbf{3 8 6}}$ Greer $v$. Spock, ${ }^{387}$ United States $v$. Kokinda, ${ }^{388}$ and International Society for Krishna Consciousness $v$. Lee, ${ }^{389}$ all reach this result, and the logic these cases employ is important for evaluating both Noerr and Parker immunity.

Adderley provided the logical basis for this line of cases. In $A d$ derley, a group of students went to a Florida jail to protest the arrest of certain other students, and to protest segregation, which was enforced at the jail. The protestors occupied the "curtilage of the jailhouse" and refused to leave when the sheriff ordered them to. ${ }^{890}$ The student-protestors were convicted of trespass and, in an opinion by Justice Black, the Court upheld the convictions. The Court reasoned that the "State, no less than a private owner of property, has power to preserve the property under its control for the use to which it is lawfully dedicated."391 Two elements of this brief quotation deserve attention. First, the Court draws a distinction between the state in its capacity as the proprietor of a prison, and the state in its capacity as an enforcer of laws. There would not normally be any question that an order from a sheriff to disperse a demonstration would be subject to the most stringent scrutiny. ${ }^{392} \mathrm{But}$, where the sheriff issues the order in his capacity as jailkeeper, the Court is willing to give greater deference to the sheriff's judgment that the demonstration must disperse. Justice Black's analogy to a private property owner reveals the Court's position that state officials are less "public" when running a jail than they are when they are per-
forming other functions.

The second point established in Adderley is that, of necessity, the state must have the power to control property to operate a jail. In the Court's terms, if property is "lawfully dedicated" to a "use," then the state has the same power as would an owner of

386. 385 U.S. 39 (1967) (addressing a demonstration on prison grounds).

387. 424 U.S. 828 (1976) (addressing a prohibition of a political rally on an army base). 388. 497 U.S. 720 (1990) (addressing efforts to solicit contributions on a sidewalk dedicated to a post office)

389. 112 S. Ct. 2701 (1992) (addressing airport regulations regarding the solicitation of
moncy and distribution of literature). moncy and distribution of literature)

390. Adderly, 385 U.S. at 47.

391. Id.

392. See, e.g., Gregory v. Chicago, 394 U.S. 111 (1969) (reversing conviction for disturbing the peace by failing to obey police order to terminate demonstration); Shuttlesthings, refusal to obey police order to disperse)
thing conviction based on, among other

private property to "preserve" that property for the lawful use. On this point even Justice Douglas's dissent agrees: "[I]t may be necessary to adjust the right to petition for redress of grievances to the other interests inhering in the uses to which the public property is normally put." ${ }^{393}$ In other words, if the state is to run a jail it needs, and therefore has the right, to control the environment in and around the jail.

With this common-sense point, the disparity between this and Justice Brandeis's Athenian model becomes apparent. Dedicating property to specific governmental purposes necessitates a division of labor within the state, which necessarily implies a division between the state and the polis. The state is managing its own affairs as a distinct entity. Some of the state's divisions will be dedicated to receiving the petitions of the polis, others will not. If putative practitioners of the freedom of speech mistake the latter for the former, according to the Adderley Court, they will not be protected by the First Amendment. While the First Amendment will provide robust protection of speech directed to the proper divisions of government, that protection should not extend into fora not dedicated to petitioning activity. Justice Black's opinion in Adderley embodies the First Amendment doctrine he forged and for which he is justly famous: What the First Amendment covers, it covers absolutely. And, what it does not cover, it does not cover at all. ${ }^{394}$

Both points made in Adderley turn on the purpose to which government property is dedicated, and that for which state officials are working. The state's power to control First Amendment activity is limited to control "for the use to which [the property] is lawfully dedicated." ${ }^{395}$ This requires that there be a connection between the limitation on speech and the state's purpose, that "[ $t]$ he reasonableness of the Government's restrictions on

393. Adderly, 385 U.S. at 54 (Douglas, J., dissenting). Prior to the portion of the dissen quoted in the text, Justice Douglas had written that "[t]here may be some public place which are so clearly committed to other purposes that their use for the airing of grievances is anomalous. ... A noisy meeting may be out of keeping with the serenity of the statehouse or the quiet of the courthouse." Id. Five years later, of course, Justice Douglas wrote that the right to petition extended to filing lawsuits with administrative agencies, with no mention of a need to "adjust" the right to petition to fit the location in which it unexpectedly found itself. California Motor Transport Co. v. Trucking Unlimited, 404 U.S. 508 (1972)

394. Adderly, 385 U.S. at 48 . For an informative discussion of this view generally, and Justice Black's views in particular, see Alexander Meiklejohn, The First Amendment Is An Absolute, 1961 Sup. CT. Rev. 245.

395. Adderley, 385 U.S. at 47 . 
[speech in a nonpublic forum] must be assessed in light of the purpose of the forum and all the surrounding circumstances," or that "the significance of the governmental interest must be assessed in light of the characteristic nature and function of the particular forum involved." 396 The cases since Adderley demonstrate that once the Court concludes that a forum is nonpublic, the Court is tolerant of restrictions on speech that plausibly relate to the purpose to which the forum is dedicated.

The Court seems to have concluded that the narrower the purpose to which a forum is dedicated, the more lenient the Court will be on speech restrictions, and vice versa. For example in Greer v. Spock ${ }^{397}$ the Court allowed the army to prohibit political campaign speeches on land frequently used by the public, largely because the military has a unique and fairly narrow mission..$^{398}$ In Krishna Consciousness the Court upheld a restriction on face-toface solicitation but struck down a restriction on leafletting. The difference in the restrictions seems to have been Justice O'Connor's view that the airport had opened itself to so many different uses that leafletting was not constitutionally inconsistent with the airport's purpose. ${ }^{399}$ She wrote, "the wide range of activities promoted by the [airports] is no more directly related to facilitating air travel than are the types of activities in which ISKCON wishes to engage." ${ }^{\text {000 }}$ The Krishna Consciousness Court measured the challenged regulation against the purpose of the forum, and suggested that fora with broader purposes will have to accommodate a wider array of speech than fora with narrower ones. ${ }^{401}$

396. International Society for Krishna Consciousness, Inc. v. Lee, 112 S. Ct. 2711, 2712 (1992) (O'Connor, J., concurring) (quoting Cornelius v. NAACP Legal Defense \& Educational Fund, Inc., 473 U.S. 788, 809 (1985) and United States v. Kokinda, 497 U.S. 720 732 (1990) (quoting Heffron v. International Society for Krishna Consciousness, Inc., 452 397. 424 U. S. $828(1970)$.

398. Id. at $837-38$.

399. Justice $O^{\prime}$ Connor noted, for example, that airports subject to the regulation contained restaurants, cafeterias, snack bars, coffee shops, cocktail lounges, post offices, banks, telegraph offices, clothing shops, drug stores, food stores, nurseries, past offices, currency exchanges, art exhibits, commercial advertising displays, bookstores, newsstands, dental offices and private clubs." ISKCON, 112 S. Ct. at 2712 400. Id. at 2713. The distinction between leafletting and personal solicitation, of
course, does not necessarily follow from this observation.

401. At a certain point the Court is likely to hold that the breadth of a forum's pur-
poses makes it a public forum. See Widmar poses makes it a public forum. See Widmar v. Vincent, 454 U.S. 263 (1981) (holding university had created a public forum by opening it facilities for use by student groups, and therefore could not prevent religious groups from using rooms it allowed secular groups
to use).

A brief examination of one other type of public forum case will complete the background needed to evaluate Noerr using First Amendment standards. This type of case addresses the use of governmental resources dedicated to competitive and quasi-competitive ends-those in which the government acts as an employer or proprietor providing a service. The illustrative cases are Comelius v. NAACP Legal Defense And Education Fund, ${ }^{402}$ and Lehman $v$. City of Shaker Heights, ${ }^{403}$ perhaps the most infamous of the public forum cases. ${ }^{404}$

At issue in Comelius was the Combined Federal Campaign, a charitable fundraising drive for federal employees. ${ }^{405}$ The campaign allowed only voluntary, charitable, health and welfare agencies that provide or support direct health and welfare services to individuals or their families to participate in the campaign by soliciting funds in a letter to federal employees. ${ }^{406}$ The NAACP Fund and similar groups were denied this opportunity. ${ }^{407}$ The government argued that the campaign was designed to accommodate the desirable goal of making charitable contributions easy for federal employees while not disrupting the workplace. ${ }^{408}$ The government contended that allowing political organizations to solicit funds through the campaign would lead to political debates at work, with an attendant decrease in job performance. Finally, the government wanted to avoid the appearance that it was siding with the view of the groups that were allowed to solicit. ${ }^{409}$

The NAACP Legal Defense and Educational Fund, and several similar but lesser-known groups, wanted to solicit funds through the campaign but did not fit this description. Each of the groups was devoted to influencing public policy through "political activity, advocacy, lobbying, or litigation on behalf of others." ${ }^{410}$ When the Court examined the groups' challenge to the government's policy, it first "looked to the policy and practice of the government to ascertain whether it intended to designate a place

402. 479 U.S. 788 (1985).

403. 418 U.S. 298 (1974)

404. Perry Educ. Ass'n v. Perry Local Educators' Ass'n, 460 U.S. 37 (1983), falls into this category as well.

405. Comelius, 473 U.S. at 790-91.

406. Id. at 792 .

407. Id. at 795 .

408. See id. at 806

409. $1 d$ at 807 .

410. Id. 
not traditionally open to assembly and debate as a public forum." ${ }^{411}$ The Court found it significant that the government had consistently imposed strict limitations on the types of groups that could solicit in the campaign. The Court concluded that the government had not turned the workplace into a public forum because it had drawn a line beyond which concerns for an orderly workplace trumped the desire to allow broad access to the campaign. ${ }^{412}$ The Court then concluded that the regulations were reasonable, and remanded the case to consider whether the plaintiffs' claim constituted viewpoint discrimination based on the political content of their messages. ${ }^{413}$

While the Court was willing to defer to the government's authority as an employer, the Court was concerned that the government would (mis) use its authority as an emnployer pretextually to pursue its policy goals. The pursuit of those goals would involve the exercise of what Professor Post has called "governance" authority, ${ }^{414}$ to which the Court gives little deference at all. ${ }^{415}$ When the state acts in a governmental capacity, the standard First Amendment rules apply. ${ }^{416}$ For the content-based distinctions at issue in Comelius, that would have required strict scrutiny. ${ }^{417}$

In Lehman $v$. City of Shaker Heights, the city of Shaker Heights acted as a market participant by operating a bus company. Shaker Heights sold advertising space on the buses operated by its municipal bus system. It refused all political advertisements. Harry J. Lehman, who was a candidate for public office, sued, claiming that the First Amendment compelled the city to accept his political advertisement. In a plurality opinion by Justice Blackmun, the Court rejected the claim that the First Amendment denied the city the discretion to refuse to accept political advertising, and noted:

\section{Id. at 802 . \\ 412. Il. at 804-05. \\ 413. Id. at $811-13$. \\ 414. Post, supra note 377.}

415. The Court has consistently held that, in its capacity as governor, the state may not use speech restrictions to favor one view over another. Though stated in innumerable cases, the most recent extensive discussion of this point may be found in the Texas flagburning case. Texas v. Johnson, 491 U.S. 391, 410 (1989) (holding that a statute prohibiting flag burning is unconstitutional).

416. For a full discussion of the application of constitutional standards to the government, see Teresa Gillen, Comment, A Proposed Model of the Sovereign Proprietary Distinction, 417. See supra 661985$)$
[T] he city is engaged in commerce. It must provide rapid, convenient, pleasant, and inexpensive service to the commuters of Shaker Heights. The car card space, although incidental to the provision of public transportation, is part of the commercial venture. In much the same way that a newspaper or periodical ... need not accept every proffer of advertising from the general public, a city transit system has discretion to develop and make reasonable choices concerning the types of advertising that may be displayed in its vehicles. ${ }^{418}$

The Court recognized that the city was acting in its proprietary capacity, and affirmed that Shaker Heights had the right to refuse political advertising because:

[ $\mathrm{t}$ ] here could be lingering doubts about favoritism, and sticky administrative problems might arise in parceling out limited space to eager politicians. In these circumstances, the managerial decision to limit car card space to . . . less controversial commercial and service advertising does not rise to the dignity of a First Amendment violation. ${ }^{419}$

In other words, from a managerial perspective, the city had the discretion to decide that leasing political advertising was potentially too controversial. If the city had discriminated among causes or candidates, the Court no doubt would have recognized that the city was using its managerial authority as cover for its policy choices and would have employed a far stricter standard of review. ${ }^{420}$

The distinction in public forum jurisprudence between the exercise of what Professor Post has called governmental and managerial authority ${ }^{421}$ provides a basis for a reasoned analysis of the variety of cases that have arisen under Noerr. Because the Court will construe the antitrust laws to avoid a conflict with the First Amendment, the first question in any Noerr case should be whether the First Amendment protects the conduct at issue. If the First Amendment does not apply, the challenged conduct may be subject to antitrust sanction, assuming the substantive requirements of antitrust liability are met. Public forum principles

418. Lehman, 418 U.S. at 303.

419. Id. at 305 .

420. Lehman was decided well before the other two cases and before the Court had undertaken to develop its doctrine in this area. Perhaps for that reason, it has provoked a wide array of academic responses. Professor Shiffrin (quoting Professor Karst) has Rev. 565, 581 (1980), while Professor Post finds ground to defend it. Post, supra note 377, at 1795 .

421. Post, supra note 377, at 1734 (arguing municipality exercises managerial authority over commercial venture in which it participated). 
provide a theoretical basis for deciding whether and, if so, how the First Amendment might apply in a given case.

Under this framework, the analysis of the continuum of petitioning activity should focus on two variables. The first is the type of speech activity at issue, and the second is the kind of governmental entity toward which the speech is directed. Thus, for example, a speech made at a town meeting would be treated differently than a letter sent to a municipal utility. ${ }^{422}$ When the governmental entity being petitioned is designed to receive and deliberate upon public grievances, the First Amendment protection of such activity would be at its greatest, and the antitrust laws could impose no sanction on the activity. When the governmental entity is designed for a different purpose, such as the formal adjudication of a specific dispute, the First Amendment protection would not be absolute, if it applied at all, and the applicability of the of the antitrust laws would be much stronger. The continuum of governmental activity can safely be represented by Congress or a state legislature at the one end, and a governmental entity acting as a market participant, such as the utility in City of Lafayelte and, at least arguably, the bus line in Lehman, at the other. Agencies engaged in rulemaking would be treated more like courts for these purposes.

Using this approach, Noerr was an easy case that could and should have been quickly decided according to basic First Amendment principles. The railroads conducted "a publicity campaign against the truckers designed to foster the adoption and retention of laws and law enforcement practices destructive of the trucking business, to create an atmosphere of distaste for the truckers among the general public." ${ }^{423}$ The conduct at issue was classic speech. By analogy to New York Times v. Sullivan ${ }^{424}$ it did not matter that the railroads had subjectively malicious inclinations towards the truckers. Given the New York Times premise that debate on public issues (of which transportation was one)

422. In some cases it may be appropriate to focus on the content of the speech as well. protection to speech on topics of public concern than to more "private" speech. See Robert C. Post, The Hustler Magazine v Falwell, Discourse: Outrageous Opinion, Democratic Deliberation, and utility complaining. Falwell, 103 HARv. L. REv. 603, 667-74 (1990). Thus, a letter to a utility complaining about the utility's compliance with the environmental laws seems intuively different than a complaint about a bill, and that intuition may plays seems intu-

23. Noen, 365 U.S. at 129

424. 376 U.S. 254 (1964). should be "uninhibited, robust, and wide-open" ${ }^{n 25}$ and the corollary, as Justice Powell later stated, that some false speech must be tolerated to avoid chilling "speech that matters," ${ }^{226}$ it is hard to see how the railroads' publicity campaign could have been sanctioned without violating the First Amendment. ${ }^{427}$ This is especially so because the relief the truckers sought included an injunction against further publicity campaigns by the railroads. ${ }^{428}$ In First Amendment jurisprudence, this would be a prior restraint, the single most suspect form of speech restriction and the one least likely to be upheld. ${ }^{429}$

Unfortunately, the easy decision in Noerr has been inappropriately applied in a wide variety of cases, primarily because the Court announced in its decision that Noerr was an antitrust case. Thus, in subsequent cases, when faced with a plausible claim that unchallenged actions should be deemed petitioning rather than part of a conspiracy to monopolize, courts have applied Noerr.

Closer to the market participant end of the spectrum of governmental fora lie the large number of cases that deal with the "petitioning" of judicial and quasi-judicial bodies. Because the Noerr cases concern anticompetitive activity, and because one of the better ways to harm competitors is to impose costs on them, Noerr has been most frequently interpreted in the context of administrative adjudications and ordinary judicial proceedings. Such proceedings offer the greatest prospect of imposing costs on competitors because petitioners (plaintiffs) in such fora gain

\section{Id. at 270}

426. Gertz v. Robert Welch, Inc., 418 U.S. 323, 341 (1974).

427. Of course, the First Amendment does not directly protect false statements of fact. Gertz, 418 U.S. at 339 (1974) ("there is no constitutional value in false statements of fact"). The plaintiffs in Noerr thus could get some mileage out of their claim that the defendants' speech was deceptive, and therefore undeserving of protection. As we shall see, however, concerns about overdeterring (or "chilling") legitimate speech may justify protecting even deceptive speech in certain circumstances. See infra section III.C.2.

\section{As Justice Black described it,}

[t]he prayer for injunctive relief was much broader, however, asking that the defendants be restrained from disseminating any disparaging information about the truckers without disclosing railroad participation, from attempting to exert any pressure upon the legislature or Governor of Pennsylvania through the medium of front organizations, from paying any public or private organizations to propagate the arguments of the railroads against the truckers or their business, and from doing ... [any similar acts.]

Noer, 365 U.S. at 131. Reading this sweeping request for injunctive relief, one gets the impression that the truckers' biggest problem was that they got greedy.

429. See, e.g. Bantam Books, Inc. v. Sullivan, 372 U.S. 58, 70 (1963) (“Any system of prior restraints of expression comes to this Court bearing a heavy presumption against its constitutional validity."). 
rights of discovery, and because the rival is forced to defend itself or risk a default judgment or adverse agency ruling.

As mentioned above, Califormia Motor Transport Co. v. Trucking Unlimiled $^{4.30}$ is the leading case. At issue were the efforts of a dominant trucking firm to keep its competitors out of the market by opposing applications its competitors had to file with two government agencies to do business in the market. ${ }^{431}$ The competitors brought an antitrust lawsuit against the dominant firm. In the course of considering the trucking firm's claim to immunity from antitrust liability, the Court issued sweeping dicta on the nature of the right to petition.

"Certainly," Justice Douglas wrote, "the right to petition extends to all departments of the Government. The right of access to the courts is indeed but one aspect of the right to petition." 432 Yet, from a First Amendment perspective, it is unclear why this proposition is "certain," if only because there are vast differences between courts and other governmental bodies to which the right to petition might apply. Courts, for example, have almost plenary power to control the actual proceedings in the courtroom. Courts may forbid the publication of material obtained in discovery to preserve the integrity of the litigation process, ${ }^{433}$ control (within limits) media coverage of a trial, ${ }^{434}$ pass rules limiting the right of attorneys to speak about a case, ${ }^{\mathbf{4 3 5}}$ place gag orders on attorneys during trial, ${ }^{436}$ and sanction the filing of "petitions" interposed for an improper purpose or filed without adequate investigation. ${ }^{437}$ An entire line of administrative law cases is devoted to the circumstances in which administrative decision-makers may engage in ex parte communications with the

430. 404 U.S. 508 (1972).

431. Id. at 509

432. Id.

433. See Seattle Times Co. v. Rinehart, 467 U.S. 20 (1984); see also Robert C. Post, The Management of Speech: Discretion and Rights, 1984 SuP. Cr. REVIEw 169.

43.1. See, e.g., Sheppard v. Maxwell, 384 U.S. 333 (1966) ("Icgal trials are not like elecper'") (reversing conviction the use of the meeting-hall, the radio, and the newspaBridges v. California, 314 U S. 252 trial tainted by adverse media coverage), quoting 435. See Gentile State Bar or 271 (1941).

435. See Gentile v. State Bar of Nevada, 111 S. Ct. 2720 (1991) (striking down sanction 436. See, e.g., Levine v. U.S. District Court 764 validity of the rule).

restraining order as appropriate remedy for excessive 590 (9th Cir. 1985) (sustaining 437. Fed. K. Civ. P. 11 . outside world, ${ }^{438}$ a set of restrictions that would be totally unthinkable in a legislative setting.

Justice Douglas did qualify his bold statement in California Motor Transport by acknowledging such obvious differences and gave an instructive example: "[m] isrepresentations, condoned in the political arena, are not immunized when used in the adjudicatory process." ${ }^{439}$ Thus, the majority concluded, the defendants had "the right of access to the agencies and courts to be heard on applications sought by competitive highway carriers. That right, as indicated, is part of the right of petition protected by the First Amendment. Yet that does not necessarily give [the defendants] immunity from the antitrust laws."

The Court's statement must be read carefully. According to the Court, the First Amendment grants a right of access-it gives a petitioner the right to get inside the courthouse door. The opinion does not indicate what level of protection is afforded to speech that takes place once the petitioner is inside. In fact, the disposition of the case indicates that the Court would allow the antitrust laws to be applied to a pattern of anticompetitive petitioning if such a pattern could be shown.

In support of its decision, the Court cited Gibboney $v$. Empire Storage $\mathcal{E}^{2}$ Ice $\mathrm{Co}_{0 .}{ }^{411}$ in which the Court had held that the First Amendment did not protect the union's coercive tactics (including picketing) against an ice company. ${ }^{442}$ The Court concluded that the union's actions in the aggregate formed "a single and integrated course of conduct, which was in violation of Missouri's valid law." ${ }^{443}$ With this background, the Gibboney Court wrote that "placards used as an essential and inseparable part of a grave offense against an important public law cannot immunize that unlawful conduct from state control. ${ }^{.444}$ The Court concluded that

438. See, e.g., Home Box Office, Inc. v. Federal Communications Commission, 567 F.2d 9 (D.C. Cir. 1976), cen. denied 434 U.S. 829 (1977)(requiring FCC to hold hearing to determine effect of ex parte contacts on agency regulation). The Home Box Office Court linked ex parte contacts to the type of public choice behavior discussed in Part II, noting that "we are concerned that the final shaping of the rules we are reviewing here may have been by compromise among the contending industry forces, rather than by exercise of the independent discretion in the public interest the Communications Act vests in individual commissioners." 567 F.2d at 53 .

439. Califormia Motor Transpon, 404 U.S. at 513.

440. Id.

441. 396 U.S. 490 (1949).

442. Id. at $492-93$. The union also persuaded the ice company's truck drivers, $85 \%$ of whom were union members, to refuse to deliver the company's ice. Id.

443. Id. at 497. 
speech or press to makeemed an abridgement of freedom of cause the conduct was in a course of conduct illegal merely beby means of language, either initiated, evidenced, or carried out Stated this way the point is a spoken, written, or printed. ${ }^{\mathbf{4 4 5}}$ quire some form of is a truism, because many crimes restrongly, the point is indisputably cotion. But even stated less sistently applied neutral speech. ${ }^{446}$ in neutral laws to cases incidentally involving

In light of this necessary qualification, the Court's sweeping statement regarding First Amendment protection becomes even more difficult to understand. A right that allows becomes even or an agency adjudication but offers not allows one into a court much of a right. ${ }^{477}$ Moreover, the idea further protection is not might pose some interesting the idea of a right of access alone mootness doctrines in viation questions. Are the ripeness and they allow courts to dismiss the merits? ${ }^{448}$ Is the congressional claims without a hearing on jects from the jurisdiction of (or even trumped by) the First federal courts in conflict with settled doctrine that the First Amendment? ${ }^{449}$ What of the well-

$$
\text { 445. } / d
$$

446. It has not done so without controversy, however. The mo was a 5 -4 decision with a vigorous dissenting opinion. The most recent case in this line S. Ct. 2513 (1991)

447. As (hief Justice Rehnquist noted in Walter vors, 473 U.S. 305,934 (1985), most of the cases add National Ass'n of Radiation Surviconnection with litigation have focused on the right fing a litigation strategy together rather than a right associate for the purpose of putbehalf of some individual. The case most often cited (beside a lawsuit seeking relief on support of a First Amendment right of access to the courts is NAACria Motor Transpont) in 415,421 (1963), which involved the right of the NAACP to NAACP v. Button, 371 U.S. tiffs, and organize litigation strategies prior to filing suit Justice Breetings, recruit plainon these cases in his concurring opinion in Califort. Justice Brennan incorrectly relied (Brennan, J., concurring). In that concurrence Justice Motor Transport. 404 U.S. at 517 ery or other misconduct, "I can see no difference, Justice Brennan stated that, absent bribAmendment are concerned, between trying to infuence the antitrust laws and the First and trying to influence administrative and judicial bonce executive and legislative bodies below, this position is simply insupportable. 448. We here assume that insupportable.

from the "case" and "controversy" language of Articially created, rather than commands doctrines this way, calling them ways of dealing with cast. Justice Brandeis referred to the tion" but that were not suitable for judicial dispositises "confessedly within our jurisdic(1936) (Brandeis, J., concurring). If as some have asion. Ashwander v. TVA, 297 U.S. 288 by Article III, the question is not as difome have argued, these doctrines are compelled 49. See Gerald Guntion is not as difficult.

ionated Guide to the Agency Debate, 36 Stan. L. Rev. 895, 905 (1984) (art Jurisdiction: An Opinals to strip the Court of jurisdiction on . REv. 895, 905 (1984) (arguing against proposhas broad discretion to enact such measures). missal of his client's case? ${ }^{450}$ How can a lawyer's ineptitude waive his client's constitutional rights?

The Court did not resolve the conflict between First Amendment values and competing interests in California Motor Transport, nor did it establish principles from which answers to these questions could be derived. It left only the proclamation that the First Amendment grants access to courts and adjudicative agency proceedings, and the result that this right of access did not compel the dismissal of a complaint alleging that the petitioning violated the antitrust laws. In fairness to the Court, however, it is hard to see what theoretical basis it could have established. Some lawsuits and agency challenges have merit and some do not. Of the meritless challenges, some are so meritless that they are sanctionable and some are not. The answer in each case must depend on the circumstances and, at least for purposes of Rule 11, the investigation done before the challenge is brought. ${ }^{451}$

As the foregoing discussion indicates, the complexities of government in the modern era dictate that some governmental entities are simply not appropriate fora for petitioning activity, and that fact poses no First Amendment problems. With respect to such fora, there should be no bar to the operation of the antitrust laws. The question remaining is whether courts and adjudicatory agencies fall into that category. Insofar as federal courts are concerned, there is strong reason to conclude that courts are not proper fora for petitioning, at least if that term is used to refer to the type of petitioning activity at issue in Noerr. Federal judges have life tenure and salary protection because their independence must be protected from any force that might distort their application of law to the facts of a case before them. ${ }^{452}$ As the Court recently stated, the Framers "established that Article III judges would be appointed, rather than elected, and would be sheltered from public opinion by receiving life tenure and salary protection. ${ }^{\text {"453 }}$ We have come to entrust the Bill of Rights to the courts precisely because they are less likely to be swayed by temporary flights of public opinion, thus ameliorating "the effects of

\footnotetext{
450. See, e.g., Ball v. City of Chicago, 2 F.3d 752 (7th Cir. 1993) (affirming dismissal based on failure to prosecute).

451. Fed. R. Civ. P. 11.

452. See The Federalist No. 78 at 469 (Alexander Hamilton)(Clinton Rossiter ed., 1961).

453. Chisolm v. Roemer, 111 S. Ci. 2354, 2367 (1991) (holding that state judges count as "representatives" for purposes of the Voting Rights Act).
} 
occasional ill humors in the society." 454 These factors should give us patuse in declaring that courts are proper fora for the type of petitioning envisioned by the First Amendment. ${ }^{455}$

There are competing considerations, of course, that make courts look more like First Amendment fora than this somewhat formal analysis would indicate. Throughout its history, the Court has handed down decisions that have radically affected the course of the nation. From the early bank cases ${ }^{456}$ through the baules battles over competing conceptions of the national good have read to give almost any cition of federal statutes that have been read to give almost any citizen standing to challenge almost any government action in court, such as the Endangered Species Act, suggests that courts could function as protected First Amendsuch as Lujan Court's battles over standing in public law cases, point because thesenders of Wildlife, ${ }^{457}$ are instructive on this exactly that these cases reflect the Court's struggle to define exactly what kind of petitioning forum it is. Even if one adheres fair question of courts as adjudicators of private rights, it is a fair question whether the Court will be able to retain that character in an era of broad statutory entitlements.

There are those who would give the Court sufficiently broad powers that one would not be surprised at their conclusion that the First Amendment should apply to judicial proceedings. ${ }^{458} \mathrm{As}$

454. See The Feneral.sst No. 78 at 469 (Alexander Hamilton)(Clinton Rossier $1961)$

45. These observations apply to federal judges; state courts may be established differcinly. Many states elect their judges, and there is nothing preventing a state from estabIshing a judiciary empowered to give advisory opinions or otherwise from estabthat the proverum for first amendment activity. The Court's recent decision in as an maly ape provisions of the Voting Rights Act pertaining to the election of "representatives" maly apply to clections for state judges, may tend to confirm this view. Nonethentatives phes the conceive for their judges a form of judicint ins, it is 456. The Court sustaind in the Federal system.

Cutlo. The Court stistained the constitutionality of the Bank of the United Stutes in McCulloch v. Marylind, 17 U.S. 316 (1819). Justice Marshall's of the United States in Mchave drawn heavily on an opinion written by Alexander Hamilion as Secase seems to Treasury when President Washington was considering whether a national Secretary of the constiutional. See DUMAs MAIONE, THE SAGE or MONTISer a national bank would be Hamilton's written opinion to Washington arguing in favor of the constituitionating that bank "hatd come into Marshall's hands in the papers of of the constitutionality of the drawn upon in his own opinion in the case of papers of Washington and was directly word for word"). There is some irony in this, McCulloch us. Maryland, sometimes almost appellation of the least dangerous branch, but there could be gave the judiciary the would have applauded the expansion of national authority by little question that he 457. 112 S. Ct. 2130 (1992) 4h8. This is not an exaggeration, as can be verified by an examination of the plaintiffs"
claims in Luyjan. These included an "ecosystem nexus" theory, $i d$. at $2138-40$, that would
Lujan demonstrates, however, that moment is not yet at hand. Quoting John Marshall, the Lujan Court argued that "the province of the Court is solely to decide on the rights of individuals." "is the function of Congress and the Chief Executive." ${ }^{460}$ The Court has attempted to maintain enough of the traditional, private litigation model to keep the exercise of its powers "judicial" in some meaningful sense, while still accommodating all the litigants Congress has sent to it. ${ }^{461}$

At present, the Court's accommodation is inconsistent with a vision of courts as public fora for petitioning activity fully protected by the First Amendment. Fortunately, from the perspective of doctrinal consistency, the Court has not applied Califormia Motor Transport to hold anything other than that there is a right of access to the courts. Once in court, plaintiffs' First Amendment rights are at the mercy of the rules of the forum. Because of the nature and purpose of these fora, the First Amendment should not impair the ability of courts and agencies to enforce their own rules, including rules designed to punish claimants who bring worthless claims and abuse the relevant judicial processes. have done for standing what Wickard $y$. Filbum did for the Commerce Clause, 317 U.S. 111 (1942) (upholding a quota applied to the production and consumption of wheat even on one individual's private property).

459. Lujan, 112 S. Ct. at 2145, quoting Marbury v. Madison, 5 U.S. (1 Cranch) 137, 170 (1803). Professor Haskins has persuasively argued that this statement was made in the context of Chief Justice Marshall's efforts to carve out an uncontroversial sphere of influence in which the Federalist-dominated judiciary could operate without fear of reprisal from the Republican party, which had recently ascended to control of the other two branches. See George L. HASkins, Foundations of PowEr: JoHn Marshall 1801-1815 (1981). Dangers such as the politically motivated if POWER: JOHN MARSHALL 1801-1815 comes to mind) seem now a remnant of the past, which might argue for a more aggressive judicial role in this new, safer environment. The Court does argue for a more aggressive dangerous enemies than it did in 1803 . On the other hand, it may be that the judiciary dangerous enemies than it did in 1803 . On the other hand, it may be that the judiciary the relatively uncontroversial line Justice Marshall marked out in Marbury. 460 . 112 S. Ct. at 2145 .

461. This is a concern that the advocates of an expansive view of standing rarely address directly. See William A Fletcher, The Structure of Standing 98 Y dress directly. See William A. Fetcher, The Structure of Sianding, 98 YaLE L. J. 221 (1988) MicH. L REv, 169 (1992). It is, however, a serious question, If Congress wishes ${ }^{2}$, 91 certain issues to the courts for resolution by, for exa question. If Congress wishes to shift certain issues to the courts for resolution by, for example, passing statutes granting vague substantive rights with plain private rights of action, what effect will that have on the
courts? 
2. The Misplaced Concern Over Chilling Speech in Judicial "Fora"

Does this First Amendment right of access provide absolute immunity from the antitrust laws? The Court's most recent case, Professional Real Estate Investors, Inc. v. Columbia Pictures Indus. ${ }^{462}$ defined the circumstances in which litigation might be deemed a "sham," and thus not protected by Noerr immunity. Professional Real Estate Investors is the most recent in a line of cases interpreting the Noerr Court's statement that

[t]here may be situations in which a publicity campaign, ostensibly directed toward influencing governmental action, is a mere sham to cover what is actually nothing more than an attempt to interfere directly with the business relationships of a justified. ${ }^{463}$ and the application of the Sherman Act would be

The Court distinguished Noerr because "[n]o one denies that the railroads were making a genuine effort to influence legislation and law enforcement practices." 464

Professional Real Estate Investors was a classic case of Noerr immunity in the litigation context. At issue were the efforts of a resort hotel to rent videodiscs to its guests for use in videodisc players installed in the rooms. Columbia and seven other major movie studios sued, claiming the rental of their movies violated their copyrights. The hotel counterclaimed, alleging that the studios had conspired to obtain a monopoly in violation of the Sherman Act. ${ }^{465}$ The Supreme Court affirmed the district court's grant of summary judgment in favor of the studios on the counterclaim.

462. 113 S. Ct. 1920 (1993).

463. Noer, 365 U.S. at 144. It is worth noting here that Justice Black apparently thought that interfering with the business relationships of a competitor could be enough cited statement that "ther the antitrust laws. This statement is surprising in light of the oftShoe Co. v. United States, 370 itrust laws protect competition, not competitors" in Brown would be maited States, 370 U.S. 294 (1962), and it seems unlikely that the statement S. Ct. 2578, 2589 (1993) ("Even an act of ptd. v. Brown \& Williamson Tobacco Corp., 113 another does not, without men an act of pure malice by one business competitor against do not create a federal lawore, state a claim under the federal antitrust laws; those laws torts committed by or awainst unfair competition, or 'purport to afford remedies for all ted)). In fairness to Justice Black, hows engaged in interstate commerce' ") (citation omittake that statement very seriously in 1968 , there is some evidence that the Court did not ters., Inc. v. United States Steel Corp. 1968 , when Noerr was decided. See, e.g., Fortner Engranted a. United States Steel Corp., 394 U.S. 820 (1968) (reversing summary judgment estate loans to prefat that wholly-owned credit subsidiary of steel company had tied real 685 (1967) (affirming jury verdict on ; Utah Pie Co. v. Continental Baking Co., 386 U.S. prices prices charged by all competitors in the relevant market decreased)

465. Professional Real Estate Investors, 113 S. Ct. at 1923-24.
The Court began its analysis by reaffirming the applicability of petitioning immunity in judicial fora. Quoting Noerr, the Court stated that "the Sherman Act does not punish 'political activity' through which 'the people ... freely inform the government of their wishes. " erators certainly informed the Court of their wishes; they sought treble damages and attorney's fees. But the Court did not explain how this amounted to "political activity." The Court then limited the "sham" exception created in Noerr by holding that litigation could not be a "sham" if it were "objectively reasonable," that is, if a reasonable person could have brought the action in good faith. ${ }^{467}$

The significance of this holding for the Court was that it foreclosed the possibility of antitrust liability simply because the plaintiff subjectively intended to harm a competitor by bringing the litigation. The Court thus created a two-tiered process in which a plaintiff must "disprove the challenged lawsuit's legal viability before the court will entertain evidence of the suit's economic viability." ${ }^{\text {468 }}$ The Court supported its decision by drawing an analogy to the tort of malicious prosecution, which requires a finding that an action be brought without probable cause before liability may be imposed. ${ }^{469}$

There are good reasons for such a rule in malicious prosecution cases, where bringing the lawsuit (with the proper degree of malice or recklessness) is the only requirement for liability. The antitrust laws do not impose liability for filing lawsuits, however, unless the substantive requirements of the antitrust statutes are also met. But even then, under the Court's rule in Professional Real Estate Investors, antitrust counterclaims get special treatment when the counterclaim is based on allegedly anticompetitive litigation. Why? In all the Noerr cases, only Justice Stevens' concurrence in Professional Real Estate Investors offers a theoretical justification for immunity: "Access to the courts is far too precious a right for us to infer wrongdoing from nothing more than

\footnotetext{
at 1926

466. Id.

468. Id. 468. Id. at 1928. The Court we subjective compoant's claim to Noer inmunity by de nents of a sham must still prove a substantive ant sertenter element almost certainly likely require only proof would have been satisfied under the Court's requirement 469. Id. at 1929 .
} 
asing the judicial process to seek an anticompetitive advantage in a doubtful case." 470 Justice Stevens attempts to justify Noerrimmucontext using a basic First Amendment concept-the chilling effect. Justice Stevens argued that if potential they would faced with possible antitrust liability for filing a suit, they would be less likely to do so. To reassure prospective litition violates the required a greater showing for claims that litigation violates the antitrust laws. For Justice Stevens, the right to

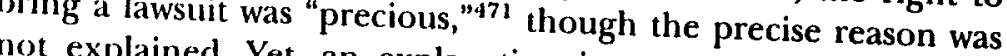
not explained. Yet, an explanation is necessary, especially bedealt with pre-litigation se. ${ }^{172}$ Only Califorion organizational efforts, not litigation per se. ${ }^{472}$ Only Califormia Motor Transport makes the jump from organizing to filing, and it is not very convincing.

Even leaving these questions aside for the moment, the idea that petitioning immunity is necessary to prevent litigation from being "chilled" is not particularly persuasive. As Professor Schauer has suggested, a better description of the "chilling" phenomenon would be "deterrence."473 This description might avoid the judicial paralysis that often accompanies a litigant's claim that his speech will be "chilled" by a given act. Deterrence is not all bad. Some types of speech should be deterred. Slander causes harm to its subject and is (by definition) of little or no social value. It follows that slander should be deterred, which is why it is a tort. Baseless lawsuits, or suits filed to obtain a collateral advantage, should also be deterred because they-impose costs on society and serve no valid purpose. The relevant question for our purposes is how much deterrence of petitioning activity is constitutionally permissible. Beginning with Speiser $v$ Randall, ${ }^{474}$ the Court has developed doctrines that "overprotect" certain kinds of speech to lessen the deterrent effect of sanctions, such as tort liability. Justice Stevens' theory would place petitioning immunity in the same category.

470. Id. at 1933 (Stevens, J., concurring).

471. Id.

472. Ste, e.g., NAACP v. Button, 371 U.S. 415 (1963); see also supra note 446.

473. See Frederick Schauer, Fear, Risk And the First Amendment: Unraveling 446.

Effect," 58 B. U. L. REv. 685 (1985) (defining chilling effect doct: Unraveling The "Chilling rence theory).

474. 357 U.S. 513 (1958) (holding state could not place on taxpayers the burden of proving they were entitled to tax exemption).
New York Times Co. v. Sullivan ${ }^{475}$ provides the best context for analyzing Justice Stevens' theory. In New York Times, the Court concluded that if liability for defamation were imposed under the standard common law rules, newspapers and other commentators would tone down their speech to stay on the safe side of the line between robust commentary and libel. As the Court explained, "A rule compelling the critic of official conduct to guarantee the truth of all his factual assertions-and to do so on pain of libel judgments virtually unlimited in amount-leads to ... self-censorship." ${ }^{476}$ The Court concluded that "[u]nder such a rule, would-be-critics of official conduct may be deterred from voicing their criticism . . . . They tend to make only statements which 'steer far wider of the unlawful zone." "477 To solve this problem, the Court created the actual malice requirement for defamation plaintiffs suing public figures. This requirement created a much higher threshold for liability to push back the line that separates libel from vigorous commentary. Under the actual malice requirement, there can be no liability unless the defendant was at least reckless with regard to the truth of his or her statement. ${ }^{478}$

In theory, the New York Times rule enables criticism for which there is some basis, to be made without fear of liability, for even if such criticism inches over the line toward libel, the defendant would still be immune from liability unless she was reckless. The difference between imposing tort liability for crossing the line between commentary and libel, and imposing tort liability only for recklessly libelous statements, creates a kind of buffer zone in which overzealous (meaning false but not knowingly or recklessly so) comments may be made. This buffer zone allows a "pure heart, empty head" defense to libel actions, and thus denies recovery to some plaintiffs who have in fact been libeled. The buffer zone denies some libel plaintiffs the recovery to which they would have been entitled under the standard common law rules. ${ }^{479}$ This departure from the common law rule was justified by reference to "a profound national commitment to the princi-

\section{376 U.S. 254 (1964)}

476. Id. at 279 .

477. Id., quoting Speiser, 357 U.S. at 526.

478. Id. at 279-80.

479. See Frederick Schauer, Uncoupling Free Speech, 92 Colum. L. REv. 1321 (1992). 
ple that debate on public issues should be uninhibited, robust, and wide-open . ..."480

When Justice Stevens stated in Professional Real Estate Investors that the right of access to the courts is too precious to be infringed by imposing liability for "using the judicial process to seek a competitive advantage in a doubtful case,"481 he endorsed rules that effectively create for antitrust cases the type of buffer zone created in defamation cases by the actual malice rule. The New York Times deterrence structure is appropriate, perhaps indispensible, in fora where uninhibited debate is the norm, such as in the media campaign in Noerr or the informational advertisements at issue in New York Times itself. Lawsuits, however, are not such a forum. As interpreted in the litigation context in Professional Real Estate Investors, Noerr immunity in the litigation context encourages plaintiffs to bring suits by making it less likely that they will be successfully sued for violating the antitrust laws by filing their original action. ${ }^{482}$ Two questions are immediately apparent: does Noerr immunity actually create a buffer zone and, if so, is such immunity desirable?

The answer to the first question must take account of the sanctions available to courts to deter litigants from bringing meritless claims or from bringing claims for an improper purpose. Potential plaintiffs must already contend with the risk of sanctions for Rule 11 violations and the possibility of malicious prosecution and abuse of process torts. Why a litigant who is not deterred by the prospect of these sanctions would be deterred by potential antitrust liability is not apparent. Rule 11 sanctions are presumably far more common than successful antitrust counterclaims. Even though the malicious prosecution and abuse of process torts do not provide for treble damages and attorneys fees, they may support punitive damage awards, which may be a more effec-

480. 376 U.S. at 270. Whether it is fair to let the loss lie on the plaintiff is another question, especially because the benefits of the New York Times rule - plaintiff is anothe ing and hus more robust debate-accrue to the public at large while the costs are bornsolely by plaintiffs who have been libeled but cannot show actual malice. One could ima inc alternative ways of achieving the benefits of the rule while dispersing could imag fitily, such as free defamation insurance for the media funded by a the costs more and television. There are of course obvious problems in administering on newspapers especially if it were to be attempted by the courts. For a provocative discussion of these issues, see Schauer, supra note 479.

481. Professional Real Estate Investors, 113 S. Ct. at 1933 (Stevens, J., concurring).

482. This lessens the potential costs of non-antitrust litigation by increasing the dis count (a function of the likelihood that a given cost will be incurred) applied to an anti-
trust counterclaim. tive deterrent. And, while there may be a due process cap on how many times a punitive damage award may exceed compensatory damages, it is greater than three. ${ }^{483}$ In light of these factors, it is hard to see why a rational plaintiff would base a litigation decision on Noerr immunity, yet only rational plaintiffs could do the type of cost-benefit calculation that Justice Stevens's concurrence seems to ennvision. It seems highly unlikely that the Noerr doctrine preserves litigation as an option in any but a trivial number of cases.

Even if an intelligible distinction could be drawn between antitrust and other types of sanctions for filing lawsuits, however, it is not at all clear that it makes sense to do so. As noted above, and as Justice Stevens aptly pointed out in Professional Real Estate Investors, litigation can serve as the means of violating the antitrust laws. ${ }^{484}$ Such litigation should be deterred, just as libel should be deterred. This fact, combined with the (at best) dubious status of courts and agencies as fora for First Amendment activity, strongly suggests that there is no interest compelling the adoption of speech-protective rules in the litigation context that is similar to the interest in uninhibited debate that supported the actual malice rule in New York Times. Debate in courts and agencies is, must be, and should be constrained by the characteristics of those fora.

This conclusion calls into question the Professional Real Estate Investors holding that objectively reasonable lawsuits are always immune from antitrust liability under Noerr. As Justice Stevens' concurrence noted, quoting Judge Posner's well-reasoned opinion in Grip-Pak, Inc. v. Illinois Tool Works, Inc., ${ }^{485}$

[ $t$ ] he existence of a tort of abuse of process shows that it has long been thought that litigation could be used for improper purposes even when there is probable cause for the litigation; and if the improper purpose is to use litigation as a tool for suppressing competition in its antitrust sense ... it becomes a matter of antitrust concern. ${ }^{486}$

It is telling that the majority and Justice Stevens's concurrence in Professional Real Estate Investors rely on two different common

483. See, eg. TXO Prod. Corp. v. Alliance Resources Corp., 113 S. Ct. 2711 (1993) (sustaining $\$ 10$ million punitive damage award based on $\$ 19,000$ compensatory damage award).

484. See Professional Real Estate Investors, 113 S. Ct. at 1933; see also supra notes 341-359 and accompanying text.

485. 694 F.2d 466, 472 (7th Cir. 1982) 486. Id. (citation omitted). 
law torts to support their analysis. The majority refers to the malicious prosecution tort, which is committed by filing a claim without probable cause. ${ }^{487}$ By contrast, the concurrence refers to the abuse of process tort, which is committed by filing a claim (meritorious or not) to obtain an advantage collateral to the proceedings. ${ }^{4 \times 8}$ Of the two analogies, the abuse of process tort best seems to fit the description of Noerr immunity that emerged from Cali. formia Motor Transport. The Court there invoked the First Amendment, but held that immunity did not extend to situations in which speech was "used as an integral part of conduct which violates a valid statute." 489 The Court did not create an exception for "speech" that was unsupported by probable cause. Rather, its language implied, and its citation to Gibboney confirmed, that the First Amendment right it was invoking would not protect a course of conduct in which speech activity was an incidental part, which is essentially the position reached by the abuse of process tort if one considers a lawsuit to be speech. ${ }^{490}$

\section{Professional Real Estate Investors, 113 S. Ct. at 1929.}

488. Id. at 1933

480. Callifurmin Motor Transport, 404 U.S. at 514.

who "instituted . . . proceedings and actions "sham" exception as applicable to litigants regardless of ... proceedings and actions ... with or without probable cause and listute Investors Court citer the cases." 404 U.S. at 512. It is ironic that the Professional Real with probable cause couth this very language with approval in holding that a suit brough 1926. The distinction such as $O$ 'Briem Trial Lawyers Ass' not to repers A.ss' n, 493 U.S. 411 (1990), a case in which a group of trial lawyers agreed not to represent indigent criminal defendants in an effort to force the local government to raise the hourly fees they would be paid for such cases. The Court sustained a finding that the lawyers had wolated the antitust laws on the ground that the alleged speech activity involved, boycotting and picketing, was the means by which the restraint of trade was imposed, not petitioning activity designed to secure the imposition of a restraint. Id. 1 428. The antitrust laws could validly regulate the restraint itself, regardless whether the form it took could nominally be deemed speech.

Prolessor Elhtunge wrongly criticized the Trial Lawyers Court on the ground that the distinction between speech as a direct restraint and speech seeking a restraint that the sulpost the result in Noerr, in which the publicity campaign was alleged to have interfered with the truckers' relationships with some of their customers. Flhauge, ory, supra note 207 at 1188 . P'rofessor Elhauge makes much too muge, Interest Group The Noerr. The only way the railroads' media campiagn could have impaired alegation in relations with their customers would have been by persuading the customers thackers' truck options, such as railroads. were better than trucks. That is customers that nonleast outside the area of incitement to civil disorder, the First simply competition. At strongly against any sort of liability based on the theory that a Amendment would cut persiaded by some sort of speech. See Boos v. Barry, 485 U.S. 312 (1988) (reaction to speech could not count as "secondary effect" under time, Even apart from these points, Justice Stevens' distinction beteen was correct. The harm in Noerr, both the veto of pro-rucking disturbance of the truckers' relationship with their customers, third parties to the media campaign, and thus on the effect of the speech on third parties.
If it is correct that petitioning immunity can rest only in the First Amendment, then the grant of immunity in Real Estate Investors seems too broad. When courts and regulatory agencies are at issue, the First Amendment has no meaningful role to play because those fora are not devoted to the airing of disputes and redressing of grievances (except those brought in accordance with court and agency procedures). Courts are instrumentally devoted to ascertaining the facts and applying the law to them. That mission requires that courts and agencies in adjudicative proceedings be given near-plenary authority to control the speech that takes place in the fora, subject to review (for the most part) only for errors affecting the substantive rights of the parties. In those situations it makes no sense to invoke the First Amendment.

As with state action immunity, Professor Elhauge has recently taken the lead in analyzing the scope and basis of antitrust petitioning immunity. ${ }^{491}$ Building on the process-based model of financial interest and government accountability he developed in the state action context, ${ }^{492}$ Elhauge has attempted to harmonize the Supreme Court's petitioning immunity cases. Professor Elhauge recognizes that the First Amendment informs the scope of petitioning immunity, but he contends that "[a]ntitrust immunity extends beyond First Amendment protections because the competitive process guarantees of antitrust are fundamentally inapplicable to disinterested accountable governmental processes of decisionmaking." 493

Our disagreements with Professor Elhauge's process-based approach were explained at some length in the previous Section. It suffices to reiterate that public actors are not as accountable as his theory must presume to achieve its goals, and private actors are not as suspect. Three points are worth mentioning here, however. First, as discussed above, petitioning, especially in the litigation or agency adjudication contexts, may have dramatically anticompetitive consequences, which are not confined to instances in which the government has a financial interest or lacks

In Trial Lauyers, by contrast, the restraint was present regardless of the reaction to the speech, or indeed regardless of what type of speech was used. Trial Lauyers was thus no more a First Amendment case than was Gibboney, which is to say it was not a case for Noem immunity.

491. Elhauge, Petitioning Immunity, supra note 178.

492. Elhauge, Antitrust Process, supra note 99, at 672.

493. Elhauge, Petitioning Immunity, supra note 178, at 1195, 1250. 
accountability. ${ }^{494}$ Antitrust law is-and properly should be-concerned with precisely the sorts of actions that petitioning immunity protects because antitrust law is concerned with economic effects on consumers, not the identity of anticompetitive actors.

Second, it makes no sense to distinguish between subjectively profit-motivated and non-profit-motivated actors for purposes of petitioning immunity, even assuming that the public choice critique of legislative behavior discussed above had no validity at all. The Court has repeatedly disavowed reliance on profit motivation as a rule of decision in the First Amendment context. Indeed, the Court summarily dismissed the argument in New York Times, holding "[ $\mathrm{t}]$ hat the Times was paid for publishing the advertisement is as immaterial in this connection as is the fact that newspapers and books are sold." 495 It is useful to remember in this connection that the Court has held that direct payments to legislators, in the form of campaign contributions of various types, may be speech. ${ }^{496}$ Yet in such a case, there can be no question that both the petitioners and the government are "financially interested." Do the petitioners therefore pay treble damages? The answer has to be "no" under the First Amendment, and it is "no" even though both the petitioners and the municipality are financially interested. ${ }^{497}$

Nor does Professor Elhauge's construct of the "objectively" disinterested actor help matters. The problem is that, as noted above, Professor Elhauge's construct includes the entire government. But, as he rightly notes, the scope of petitioning immunity varies depending on the forum in which the petitioning takes place. For example, Professor Elhauge concedes that "[a] ntitrust immunity is narrower in the adjudicative process." 498 But his the-

\footnotetext{
494. See supra section III.A

495. New York Times Co. v. Sullivan, 376 U.S. 254, 266 (1964).

496. Buckley v. Valeo, 424 U.S. 1 (1976) (holding that the Federal Election Campaign Act's expenditure restriction violated the First Amendment). In fairness to Professo Elhauge's theory, one must admit that Buckley is an odd decision. It would be hard to improve on Anthony Lewis's report of Professor Freund's reaction to the case: "They say that money talks. We thought that was the problem, not the solution." Anthony Lewis, In Memuriam: Paul A. Freund, 106 HaRv. L. REv. 16, 17 (1992)

497. Suppose in Noer the governor of Pennsylvania owned stock in the railroads that were ruming advertisements urging him to sign legislation that would hurt the truckers. Even if he did, and even if both he and the railroads got richer because of his action, it is inconceivable that the railroads could be held liable for treble damages if all they did was publically call for the governor to sign the legislation. This conclusion would not change one bit if we knew to a cerainty that the governor's decision would not cost him a single vote at the next election. Yet in that circumstance, he could hardly be called accountable, and he would by definition be interested in the restraint he imposed.

498. Elhauge, Interest Group Theory, supra note 207, at 1226.
}

ory offers no way to explain this narrower scope of immunity because judges under his theory are just as accountable as legislators. ${ }^{499}$ If they are just as accountable, how can immunity for actions before judges be narrower? First Amendment theory can provide the necessary explanation, as has been demonstrated above, but notions of accountability and context cannot.

\section{Recommendations}

The petitioning immunity doctrine must be reformed along First Amendment lines. The Court's efforts to avoid creating a constitutional issue have prevented it from undertaking a serious constitutional issue have prevented it from undes it implicitly admits are at work in the petitioning immunity cases. The Court should are at work in the petitioning immunity cases. The to distinguish among the range of petitioning activities that might come before it. As mentioned above, this should result in a continuum running from full First Amendment protection for Noerr-style publicity campaigns to minimal protection, in the form of a right of access and no more, in the litigation context.

As with the state action cases, the Court should fully apply antitrust laws a free hand where the conduct at issue does not receive First Amendment protection. This does not mean, as the Court has implied on many occasions, that the antitrust laws will be used to regulate the scope of the right to petition, any more than the antitrust laws would have been used to enforce the nondelegation principles applied in Ticor. Instead, the approach suggested here works from the premise that the antitrust laws apply to all conduct that would violate their terms, except in cases where such conduct is protected by an interest superior to cases where such conduct is protected by an inendment. Where no those of antitrust law, such as the First Amendment. Where no
such protection exists, there is no reason not to apply the antitrust laws.

112 ("An actor is politically accountable in the special sense 1 mean

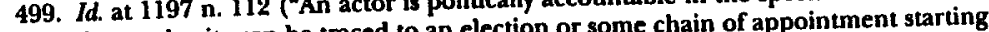
if his or her authority can be traced to an election or some chain of appoin ongoing (it emwith elected officials. The accountability can be retrogressive rather than ongoing (it enbraces judges with life tenure who were initially appointed by elected officials). ....). This broad, formal definition of accountability is necessary to Professor Elhauge's theory because, as noted above, the theory is a restatement of the state action-private action distinction. The theory cannot explain distinctions 


\section{Conciusion}

The antitrust immunity doctrines, both for state action and for petitioning, exist because in a democracy there must be room for a dialogue between the governors and the governed. That dialogue often involves parties seeking anticompetitive results, using anticompetitive means, or both. All this conduct is of potential concern to the antitrust laws, which exist to protect consumers from the adverse effects of restraints on competition. The antitrust laws themselves have no preference for or against petitioning or state action. Those laws are concerned only with protecting consumers and competition. The antitrust laws apply to problems involving restraints on competition unless they are preempted by a superior rule of law. Both federalism and the First Amendment are such rules and, in some circumstances, both federalism and the First Amendment will stay the hand of the antitrust laws to further other, superior interests.

To ascertain the scope of antitrust immunity, courts must look to the substantive law governing federalism and the First Amendment. For if valid federalism or First Amendment concerns apply in a case, the antitrust laws will not. By the same token, if such concerns are not applicable in a given case, the antitrust laws either will or will not apply based solely on the merits of the antitrust claims asserted. The search for a preference in the antitrust laws for a residual grant of power to courts to implement public choice theories of legislation, or for a preference for nonprofit decisionmaking over profit-motivated decisionmaking, will ultimately fail because the antitrust laws simply will not ${ }^{-}$bear the weight ascribed to them by such theories. 